\title{
Register of New Fruit and Nut Cultivars List 43
}

\author{
John R. Clark, Co-editor \\ Department of Horticulture, Plant Science 316 \\ Univ. of Arkansas \\ Fayetteville, AR 72701 \\ Chad E. Finn, Co-editor \\ Horticultural Crops Research Laboratory \\ U.S. Department of Agriculture-Agricultural Research Service \\ 3420 NW Orchard Avenue \\ Corvallis, OR 97330
}

\begin{abstract}
Crop Listings': Apple, Apple Rootstock, Apricot, Apricot Rootstock, Blackberry and Hybrid berry, Blueberry, Blue Honeysuckle, Cherry Rootstock, Cherry-Sweet, Gooseberry, Grape, Grape Rootstock, Nectarine, Peach, Peach Rootstock, Pear, Pecan, Plum and Plum Hybrids, Plum Rootstock, Raspberry, Strawberry, Tropical Fruit: Acerola, Avocado, Mango
\end{abstract}

\section{APPLE}

James Luby and David Bedford

Dept. of Horticultural Science

Univ. of Minnesota, St. Paul

8S6923. See Aurora Golden Gala ${ }^{\mathrm{TM}}$.

Ariane. Apple scab (Venturia inaequalis) resistant with attractive fruit, excellent flavor, long storage life. Origin. INRA, Angers, France, by F. Laurens, Y. Lespinasse, and A. Fouillet. P7R25A27 (Florina X Priam) X P21R4A30 (Golden Delicious X unknown); cross made in 1979; selected in 1988; tested as X6407. Fruit: matures with Golden Delicious; medium; flat-globose; skin $75 \%$ to $100 \%$ bright red over yellow ground color with many conspicuous lenticels and russet sometimes present in stem end; firm, crisp, and juicy flesh; stores 7 months; early harvested fruit can show storage scald. Tree: very vigorous with little branching; annual cropping with tendency to have clusters of small fruit on old branches making thinning necessary; resistant to apple scab races 1-5 with Vf gene but susceptible to race 6; some resistance to fire blight (Erwinia amylovora) and powdery mildew (Podosphaera leucotricha); susceptible to rosy apple aphid (Dysaphis plantaginea).

Aurora Golden Gala ${ }^{\mathrm{TM}}$ (cv. 8S6923). Midseason yellow, dessert apple with excellent texture and keeping quality. Origin. Agriculture and AgriFood Canada, Summerland, B.C., by C. Hampson, R. MacDonald, H. Quamme, D.-L. McKenzie, and W.D. Lane. Splendour x Gala (Kidds D.8); cross made in 1981; tested as 8S-69-23. Fruit: medium; globose to globose-conic; weakly ribbed; skin thin to medium, tender, glossy, smooth, yellow or greenish-yellow sometimes having $10 \%$ or less light red blush; extremely crisp, firm, juicy, sweet; stores approx. 6 mo. Tree: moderate vigor; spreading habit with abundant spurs; very heavy fruit set requires prompt thinning; susceptible to apple scab; partially resistant to powdery mildew.

Civni. See Rubens ${ }^{\circledR}$.

Co-op 29. See Sundance ${ }^{\mathrm{TM}}$.

Co-op 33. See Pixie Crunch ${ }^{\mathrm{TM}}$.

Co-op 39. See Crimson Crisp ${ }^{\mathrm{TM}}$.

Co-op 43. See Juliet ${ }^{\mathrm{TM}}$.

${ }^{2}$ Special thanks to the crop contributors for compiling this information. Individuals with cultivars to describe should contact the crop editors directly.
Crimson Crisp ${ }^{\mathrm{TM}}$ (cv. Co-op 39). Very crisp, attractive midseason apple with Vf resistance to apple scab. Origin: Purdue-Rutgers-Illinois cooperative breeding program, by J. Janick, J. Goffreda, and S. Korban. PCFW2-134 x PRI 669-205; cross made in 1971; selected in 1979; tested as PRI 2712-7. USPP applied for. Fruit: medium; oblate to round; skin medium-thick, glossy, not waxy following storage, with $95 \%$ to $100 \%$ red purple color; flesh yellow, very crisp and breaking; rich sub-acid flavor. Tree: moderate to low vigor; round habit, nonspur; biennial bearing if overcropped; resistant to apple scab (Vf), susceptible to cedar apple rust (Gymnosporangium juniperi-virginianae) and fire blight.

Dalitron. Distinctive bright yellow colored apple with long-term storage potential. Origin: Angers, France, by G. Ligonniere. Golden Delicious x Pilot; cross made in 1994; selected in 1997. USPP applied for. Fruit: large; truncate conical, round to elongated; little or no ribbing; skin has no bloom but medium to strong greasiness, greenish-yellow at harvest turning to bright yellow following storage; flesh creamy-white, medium to fine texture, firm, crunchy, juicy; complex aroma of banana and exotic fruit flavors. Tree: high vigor; upright-spreading.

Eden $^{\text {TM }}$ (cv. SJCA38R6A74). A nonbrowning apple with possible use for fresh slices or drying, similar to McIntosh or Cortland but firmer, crisper flesh and longer shelf life. Origin: Agriculture and Agri-Food Canada, Quebec, by S. Khanizadeh. Linda x Jonamac; cross made in 1971; tested as A38R6A74. Fruit: medium to very large; flat-globose or globose; skin medium thick, washed-out dark red over greenish-yellow ground color; flesh white, firm, juicy, crisp yet melting with fine texture; total phenols content very low; flesh does not brown after slicing for up to 3 months. Tree: moderately vigorous; spreading, drooping growth habit; fruit borne on spurs; susceptible to apple scab but no powdery mildew or fire blight observed in Quebec.

Galarina $^{\mathrm{TM}}$. A Gala-like apple resistant to apple scab and retains eating quality longer. Origin: Fruit and Ornamental Breeding Unit of the Institut National de la Recherche Agronomique, Angers, France. Gala x Florina Querina; cross made in 1978; tested as X4982 in Quebec by Agriculture and Agri-Food Canada. Fruit: matures 1-2 d after Gala; medium size; round-conic; skin color is $65 \%$ to $100 \%$ orange-red over greenish-yellow ground color with russeting in the cavity; flesh yellowish-white and browns slowly, crisp, juicy, very firm; flavor aromatic and slightly tart; stores 4.5 months. Tree: moderately vigorous; upright-spreading habit; Vf resistance to apple scab.

Jazz ${ }^{\circledR}$ (cv. Scifresh). Fresh-market apple with excellent crispness. Origin: The Horticulture and Food Research Institute of New Zealand Limited, Havelock North, New Zealand, by A. White. Braeburn x Royal Gala; cross made in 1985. USPP 13,888. Fruit: small to medium; short globose to conical with no ribbing; skin smooth, no bloom, slight 
greasiness, small lenticels, yellow-green ground color with $75 \%$ red overcolor and little russet in stem cavity; flesh yellowish-white, firm, juicy and crisp, medium texture; flavor balanced and aromatic; ripens $\geq 1$ week before Braeburn; stores for at least 5 months Tree: medium vigor; spreading habit; bears on spurs.

Juliet $^{\mathrm{TM}}$ (cv. Co-op 43). Late season, disease resistant, long storing. Origin: Purdue-Rutgers-Illinois by D. Dayton, S. Korban, J. Goffreda, J. Janick. PRI1018-101 x Viking; cross made in 1970; selected in 1977 at Urbana, Ill., by D.F. Dayton; tested as PAR14T238 and Co-op 43. USPP applied for. Fruit: large; round-oblate; smooth, waxy, moderately thick skin; $60 \%$ to $90 \%$ medium red over yellow-green ground color; full flavored, sub-acid to mild; low ethylene generation; maintains crisp texture for over 12 months; can have bitter pit. Tree: moderately vigorous; spreading habit; semi-spur type; crops annually with little blind wood; has Vf gene for apple scab resistance; resistant to powdery mildew and fire blight.

Lynn. Pink-red blushed fruit that ripen $5 \mathrm{~d}$ after Delicious with color similar to Cripps Pink but matures earlier and is more tart. Origin: Rock Island, Wash., by B. Nelson. Seedling of unknown parentage; selected in 1999. USPP 14,314. Fruit: large; round-conic; no ribbing; skin medium-thick, glossy, not greasy, $20 \%$ to $80 \%$ bright pink-red over yellow ground color; flesh creamy-white, medium firm, crisp and juicy, becoming melting after long storage; sub-acid to acidic flavor; stores 4 months. Tree: high vigor; upright habit; annual bearing.

MacExcel.Hardy, disease resistant, columnar apple. Origin: Agriculture and Agri-Food Canada, by Shahrokh Khanizadeh, Johanne Cousineau, Raymond Granger, Yvon Groleau, Gilles Rouselle, and Lloyd Spangelo. O-522 x McIntosh Wijcik; cross made in 1971; selected in 1992; tested as FER5A38; introd. in 2002. Fruit: medium; oblate to round conic with some ribbing; smooth, medium-thick skin; blotched and striped red to dark red over green-yellow ground color; heavy bloom; creamy white flesh; mild flavor; stores up to 2 months. Tree: moderate vigor; columnar habit; has Vf gene for apple scab resistance; resistant to powdery mildew.

MC38. Late-season, round, almost spherical fruit with more color and greater firmness than Cripps Pink. Origin. Harcourt, Australia, by A. McLean. Seedling of unknown parentage found in 1999 in block of Cripps Pink. USPP applied for. Fruit: medium to large; spherical, no ribbing or lobes; skin thick, not greasy after storage, solid striped red over yellowgreen ground color, conspicuous lenticels, no russet; flesh white, firm, moderately juicy; tart, full-bodied flavor and moderate aroma; stores for 4 months Tree: medium vigor; erect, strong apical dominance.

Nicola $^{\mathrm{TM}}$ (cv. SPA440). Attractive large, sweet, late-season apple. Origin: Agriculture and Agri-Food Canada, Summerland, B.C., by C. Hampson, R. MacDonald, H. Quamme, D.-L. McKenzie, and W.D. Lane. Splendour x Gala (Kidds D.8); cross made in 1981; selected in 1988; tested as 8S-26-10. Fruit: large; globose to globose-conic and weakly ribbed; skin smooth, glossy, medium-thick with little russet on cheeks but common in cavity and conspicuous lenticels with $85 \%$ red blush; flesh cream to light yellow, juicy, firm, crisp, slightly coarse; flavor starchy and slightly astringent at harvest but developing in storage to sweet and aromatic; stores well for 5 months. Tree: moderate vigor; spreading habit; bears on spurs and short shoots; needs thinning; good precocity; susceptible to apple scab.

Pixie Crunch ${ }^{\mathrm{TM}}$ (cv. Co-op 33). Small, very crisp, midseason apple with Vf resistance to apple scab. Origin: Purdue-Rutgers-Illinois cooperative breeding program, by J. Janick, E. Williams, J. Goffreda, and S. Korban. PCF2-134 x PRI 669-205; cross made in 1971 at Cream Ridge Research and Development Center, Rutgers Univ.; selected at Purdue Univ. in 1978 by E.B. Williams; tested as PRI 2712-1. USPP 13,871. Fruit: small to medium; round-oblate and no ribbing; skin thin and glossy, washed red-purple over greenish-yellow or yellow ground color; flesh yellow- white, very crisp and breaking; rich sweet-tart flavor and slight aroma; storage for 2 months. Tree: moderate vigor; spreading habit; nonspur bearing; biennial bearing if overcropped; Vf resistance to apple scab; moderately resistant to fire blight and frogeye leafspot (Physalospora obtuse); susceptible to powdery mildew and cedar apple rust.

Rebella. Early-midseason dessert apple with resistance to multiple diseases. Origin: Bundesanstalt fur Zuchtungsforschung an Kulturpflanzen, Dresden-Pilnitz, Germany, by Christa Fischer. Golden Delicious x Remo; selected in 1986. USPP 15,134. Fruit: small to medium; oblong, ellipsoidal-conical; skin thin, red over yellow ground color; flesh creamy-white, crisp, firm; balanced, aromatic flavor; stores 2 months. Tree: medium vigor; spreading, upright, pyramidal; resistant to apple scab, powdery mildew, fire blight, Pseudomonas syringae, and red spider mite (Panonychus ulmi).

Reinette Russet $^{\mathrm{TM}}$. Alternative to Golden Russet for cider production with larger fruit, more cold hardy and partial resistance to apple scab. Origin: Selected as bud mutation of Reine des Reinettes at Fruit and Ornamental Breeding Unit of the Institut National de la Recherche Agronomique, Angers, France; further evaluated in Quebec as X4362. Fruit: medium; variable shape from round-conic or flat round-conic to oblate; skin brownish-yellow, medium thickness and very rough with fine to medium russet and large swollen lenticels; flesh greenish-white, juicy, breaking and firm; rich sweet flavor and tannins that contribute to cider quality. Tree: weak to moderate vigor; upright, spreading habit; resistant to apple scab in Quebec but partially resistant in France; resistant to powdery mildew and fire blight.

Rubens $^{\circledR}$ (cv. Civni). Origin: Consorzio Italiano Vivaisti, Ferrara, Italy, by M. Leis, G. Castagnoli, and A. Martinelli. Elstar x Gala. USPP 14,177. Fruit: medium to large; conical-truncated, slightly asymmetrical; skin smooth, medium-thick, slightly greasy when overripe, $60 \%$ to $100 \%$ red to red-orange overcolor and greenish-yellow ground color; flesh creamy-white, medium texture, firm, juicy; flavor sweet and aromatic; matures approx $10 \mathrm{~d}$ after Gala; stores 6-7 months. Tree: medium vigor; upright habit; annual bearing on spurs; susceptible to apple scab; slightly susceptible to powdery mildew.

Scifresh. See Jazz ${ }^{\circledR}$.

SJ 303. Midseason apple with excellent taste, appearance, and storage ability. Origin: Thompsons Brook, Western Australia, by J. Brouwer, R. Atherton, and C. Portman. Parents unknown but probably Granny Smith and Lady Williams; selected in 1998. USPP applied for. Fruit: medium; round, no ribbing; skin has little bloom and not greasy, $\geq 70 \%$ red blush and stripe over green-yellow ground color; flesh white, medium texture, moderately aromatic, juicy, and firm; stores 6 months. Tree: high vigor; upright to spreading habit.

\section{SJCA38R6A74. See Eden ${ }^{\mathrm{TM}}$.}

SPA440. See Nicola ${ }^{\mathrm{TM}}$.

Stella Minnesota. Early season apple with nonbrowning flesh, excellent quality, and long storage life for season. Origin: Cox Apple Orchard, Cleveland, Minn., by W. Cox. Seedling of unknown parentage. USPP 13,930. Fruit: medium to large; moderately oblate; skin medium- thick, smooth with slight bloom and no greasiness, 60-90\% red overcolor and yellow ground color, prominent starburst markings and lenticels; flesh white, slow to brown, firm, crisp and juicy; balanced flavor; stores 7 weeks. Tree: medium vigor; spreading habit; annual bearing on spurs with no premature dropping; slightly susceptible to apple scab and cedar apple rust; slightly resistant to fire blight.

Sundance $^{\mathrm{TM}}$ (cv. Coop 29). Late season, attractive yellow apple with Vf resistance to apple scab. Origin: Purdue-Rutgers-Illinois cooperative breeding program, by J. Janick, E. Williams, J. Goffreda, and S. Korban. 
Golden Delicious X 1050NJ-1; cross made in 1964; selected in 1972; tested as PRI 2052-4. USPP 13,819. Fruit: large; round-conic with no ribbing; skin thin and glossy, yellow or greenish-yellow with occasional orange-red blush, stem-end russet; flesh yellow-white, moderately firm; spicy citric flavor. Tree: moderate vigor; upright habit; resistant to apple scab, fire blight, and cedar apple rust; moderately tolerant to powdery mildew.

UEB 3264/2 (Opal). Similar fruit in color and flavor to Golden Delicious with longer storage and Vf resistance to apple scab. Origin: Institute of Experimental Botany, Czech Republic, by J. Tupy, O. Louda, and J. Zima. Golden Delicious X Topaz; selected in 1999. USPP 15,963. Fruit: medium; globose to slightly conic; skin medium-thick without bloom or greasiness and yellow ground color occasionally with orange blush; flesh yellowish, medium texture; sweet, balanced, aromatic flavor; late season ripening; stores for 6 months. Tree: medium vigor; upright to spreading habit; annual bearing on spurs and shoots; Vf resistance to apple scab; tolerant to powdery mildew.

UEB 3375/2. Tree and fruit similar to Golden Delicious but matures slightly later and has globose shape, absence of russeting in stem cavity, and resistance to apple scab. Origin: Institute of Experimental Botany, Czech Republic, by J. Tupy, O. Louda, and J. Zima. Topaz $\mathrm{x}$ Golden Delicious; selected in 1999. USPP 16,084. Fruit: mediumlarge; globose; skin medium to thin, smooth with yellow ground color and occasionally a slight orange blush; flesh yellowish, fine texture; balanced flavor; stores for 6 months. Tree: medium vigor; spreading habit; annual bearing on spurs and shoots; Vf resistance to apple scab; tolerant to powdery mildew.

\section{APPLE ROOTSTOCK}

\section{Gennaro Fazio}

Plant Genetic Resources Unit, USDA-ARS, Geneva, N.Y.

Geneva $^{\circledR} 11$ (cv. G.11). A dwarfing apple rootstock. Origin: New York State Agricultural Experiment Station and Cornell Univ., Geneva, N.Y. by J. Cummins, H. Aldwinckle, and T. Robinson. Malling 26 x Robusta 5; tested as CG.3011; introd. in 1999. USPP 11,070. Plant and Rootstock Performance: Produces a scion tree that is similar in size to M.9 ( 30\% to $40 \%$ the size of trees on seedling rootstock); moderate fire blight (Erwinia amylovora) tolerance (similar to M.7); good resistance to Phytophthora cactorum; not resistant to woolly apple aphids; has shown excellent propagation characteristics in the stoolbed and in the nursery; in the orchard it produces very few burrknots or root suckers. Geneva $^{\circledR} 11$ induces large fruit size (similar to M.9); tested in two national NC-140 trials and in several NY state trials and has imparted a scion tree size slightly smaller or slightly larger than M.9 with yield efficiency as good or in some cases significantly better than M.9; also tested in France, Germany, Italy, Spain, and Poland where trees were $15 \%$ smaller than M.9Pajam2 but with $14 \%$ greater productivity and similar fruit size as M.9Pajam2; best suited for high-density plantings of 2000-4000 trees/ha.

Geneva ${ }^{\circledR} 16$ (cv. G.16). A dwarfing apple rootstock. Origin: New York State Agricultural Experiment Station, and Cornell Univ., Geneva, N.Y. by J. Cummins, H. Aldwinckle, and T. Robinson. Ottawa $3 \times$ Malus floribunda; tested as CG.3016; introd. in 1998. USPP 12,443. Plant and Rootstock Performance: Produces a scion tree that is the size of vigorous clones of M.9 such as M.9Pajam2 or Nic29, 35\% to $40 \%$ the size of trees on seedling rootstocks; resistant to fire blight, $P$. cactorum; tolerant to apple replant disease; not resistant to woolly apple aphids; hypersensitive to the three common latent viruses (Apple stem grooving,
Apple stem pitting and Chlorotic leaf spot viruses) and infected scion wood results in death of the trees in the nursery or in the first two years in the orchard; has shown good propagation characteristics in stoolbeds with very vigorous growth of nursery trees and during the first 2 years in orchard plantings; nursery propagation requires virus free scion wood to ensure success; has very good mid-winter hardiness but can be susceptible to early winter freeze events in the nursery or during the first few years in the orchard when it grows vigorously. Geneva ${ }^{\circledR} 16$ has shown very high yield efficiency (similar to M.9) and does not produce burrknots or root suckers; it induces fruit size similar or slightly less than M.9; best suited for high density plantings of 2000-4000 trees/ha.

Geneva $^{\circledR} 41$ (cv. G.41). A dwarfing apple rootstock. Origin: New York State Agricultural Experiment Station, Cornell Univ. and USDA-ARS, Geneva, N.Y. by J. Cummins, H. Aldwinckle, T. Robinson, and G. Fazio. Malling 27 x Robusta 5; tested as CG.3041; introd. in 2005. USPP pending. Plant and Rootstock Performance: Produces a scion tree that is similar in size to M.9 T337 ( 30\% the size of trees on seedling rootstock) and is similar in tree size and yield efficiency to Geneva ${ }^{\circledR} 16$ but does not have the virus sensitivity of G.16; in France was shown to be smaller in tree size to M.9Pajam2; highly resistant to fire blight and $P$. cactorum; tolerance to woolly apple aphids unknown; very winter hardy; stoolbed performance indicates it is a shy rooter and will require the use of tissue culture mother plants to improve its rooting; produces some side shoots in the stoolbed and produces very few burrknots or root suckers. Precocity and productivity have been exceptional, surpassing M.9; scion performance has shown excellent fruit size and inducement of wide branch angles; graft union strength similar to M.9 and will require a trellis or individual tree stakes; best suited for high-density plantings in fire blight-prone areas and may be the best alternative to M.9 in high fire blight areas; should be planted at densities of 2000-4000 trees/ha.

Geneva $^{\circledR} 202$ (cv. G.202). A semi-dwarfing apple rootstock. Origin: New York State Agricultural Experiment Station, Cornell Univ., and USDA-ARS, Geneva, N.Y. by J. Cummins, H. Aldwinckle, T. Robinson, and G. Fazio. Malling 27 x Robusta 5; tested as CG.4202; introduced in New Zealand in 2002 in the USA in 2004. USPP pending. Plant and Rootstock Performance: Produces a scion tree that is slightly larger in size than M.26 or $~ 50 \%$ the size of trees on seedling rootstock; resistant to fire blight, Phytophthora cactorum, and woolly apple aphid; performs moderately well in the stoolbed and produces good quality nursery trees; precocity and productivity imparted to the scion have been similar to M.26; produces very few burrknots or root suckers. Productivity in New Zealand was found to be much more than M.26; best suited for regions that have problems with woolly apple aphid; should be planted at densities of 1500-2500 trees/ha.

Geneva ${ }^{\circledR} 935$ (cv. G.935). A semi-dwarfing apple rootstock. Origin: New York State Agricultural Experiment Station, Cornell Univ., and USDA-ARS, Geneva, N.Y. by J. Cummins, H. Aldwinckle, T. Robinson, and G. Fazio. Ottawa 3 x Robusta 5; tested as CG.5935; introd. in 2005. USPP pending. Plant and Rootstock Performance: Produces a scion tree slightly larger in size than M.26 or $\sim 50 \%$ the size of trees on seedling rootstock; resistant to fire blight and $P$. cactorum; not resistant to woolly apple aphid; has good propagation characteristics in the stoolbed and produces a large tree in the nursery; is the most precocious and productive semi-dwarf CG rootstock available. Scion performance in nationwide tests has shown similar or better yield efficiency than M.9 along with induction of excellent fruit size and wide crotch angles; produces very few burrknots or root suckers; is very winter hardy; produces a freestanding tree but often high crop loads require a support system; is best suited for moderate tree densities with a minimal support system or with high planting densities of spur type scions; orchards should be planted at densities of 1500-2500 trees/ha. 


\section{APRICOT}

Craig A. Ledbetter

USDA-ARS

San Joaquin Valley Agricultural Sciences Center

Parlier, Calif.

Kettleman. Firm and highly colored early season apricot for the fresh market. Origin: Parlier, Calif., by USDA-ARS by Craig A. Ledbetter; open-pollinated seedling of K104-98; selected in May 1992; tested as K706-88;introd.in 2005. Fruit: freestone; deep-orange color that develops early in fruit maturation; firm and juicy with characteristic apricot aroma when well-matured; nearly synchronous fruit maturation throughout tree; matures in the early season between Earlicot and Castlebrite. Tree: vigorous and spreading in growth habit; self-incompatible flowers with an early bloom period; plentiful spurs with easy renewal.

Suaprinine. Large-fruited, early season, fresh-market apricot. Origin: Wasco, Calif. by David W. Cain and Terry A. Bacon, Sun World International, LLC. 063-160 x 90A-006; selected in 1996; tested as 92A004-109-164; USPP pending. Fruit: maturity 11 d before Castlebrite with harvest window 6-14 May in Wasco area; large fruit averaging 110 $\mathrm{g}$; firm, deep orange flesh with good eating quality and storage potential; $14 \%$ SS with balanced acidity, mildly tart flavor; skin $40 \%$ red over yellow-orange ground color. Tree: spreading growth with complex branching habit; self-compatible flowers; $450 \mathrm{~h}$ chilling requirement; consistent cropping even in years when most cultivars exhibit lack of chill symptoms at Wasco.

Suapriten. Large-fruited, early season, fresh-market apricot. Origin: Wasco, Calif. by David W. Cain and Terry A. Bacon, Sun World International, LLC. 063-160 x 90A-006; selected in 1996; USPP 15,999, assigned to Sun World International, LLC. Fruit: maturity $5 \mathrm{~d}$ before Castlebrite with harvest window 10-18 May in Wasco area; large fruit averaging $115 \mathrm{~g}$; firm, deep-orange flesh with good eating quality and storage potential; $15 \%$ SS, low acidity, mild flavor; skin $40 \%$ red over yellow-orange ground color. Tree: spreading growth with mediumcomplex branching habit; self-incompatible flowers; $450 \mathrm{~h}$ chilling requirement.

\section{APRICOT ROOTSTOCK}

\section{T.G. Beckman}

USDA-ARS Southeastern Fruit and Tree Nut

Res. Laboratory

Byron, Ga.

Barrier 1. Compatible with apricot cultivars. Described under Peach Rootstock.

\section{BLACKBERRY AND HYBRID BERRY}

\section{John R. Clark}

Department of Horticulture,

Univ. of Arkansas, Fayetteville

Chad E. Finn

USDA-ARS, Northwest Center for

Small Fruit Research, Corvallis, Ore.

APF-8. See Prime-Jan ${ }^{\mathrm{TM}}$.

APF-12. See Prime-Jan ${ }^{\mathrm{TM}}$.

Black Diamond. A thornless, trailing, firm-fruited blackberry that is primarily suited for machine harvesting and processing but is also suited for local fresh-market sales. Origin: U.S. Dept. of Agriculture-Agricultural
Research Service, Corvallis, Ore., by Chad E. Finn, Brian M. Yorgey, Bernadine C. Strik, Harvey K. Hall, Robert R. Martin and Michael Qian. Kotata X NZ 8610L-163; cross made in 1991 by H. Hall with New Zealand HortResearch Inc. in New Zealand; selected in 1997 by C. Finn in Corvallis, Ore.; tested as NZ9128R-1; introd. in 2005. Fruit: medium, $6 \mathrm{~g}$; firm; attractive and glossy; uniform and conical; excellent drupelet set; very good flavor; soluble solids and titratable acidity comparable to Marion and greater than Chester Thornless; as individually quick frozen (IQF) fruit ranked similarly to Marion in color and appearance but lower for flavor, seediness and overall quality; as a puree, ranked similar to Marion for aroma, flavor, color, and overall quality; ripens in midseason with the harvest midpoint $2 \mathrm{~d}$ before Marion and later than Siskiyou; fruit are readily harvested by machine with excellent quality. Plant: trailing canes; thornlessness from Austin Thornless; healthy but less vigorous than Marion; productive, comparable yield to Marion; not particularly susceptible to Septoria leaf spot (Mycosphaerella rubi) and purple blotch (Septocyta ruborum); no vegetative or fruit symptoms of cane or leaf rust (Kuehneola uredinsis); hardiness not well tested but has survived $-8{ }^{\circ} \mathrm{C}$ in northern Washington when Marion was severely damaged.

Black Pearl. A thornless, trailing blackberry, that can be machine harvested with excellent processing quality. Origin: U.S. Dept. of Agriculture-Agricultural Research Service, Corvallis, Ore., by Chad E. Finn, Brian M. Yorgey, Bernadine C. Strik, Robert R. Martin and Michael Qian. ORUS 1122-1 x ORUS 1117-11; cross made in 1993; selected in 1995; tested as ORUS 1380-1; introd. in 2005. Fruit: medium, $6.2 \mathrm{~g}$; long conic with a blunt tip; drupelet arrangement is uneven, similar to Marion; too soft for fresh market but firm enough for very good machine harvest quality; excellent flavor; soluble solids and titratable acidity comparable to Marion and greater than Chester Thornless; as an IQF fruit ranked higher than Marion for color, seediness and appearance and similar for flavor and overall quality; as a puree, ranked similar to Marion for aroma, flavor, color, and overall quality; ripens in midseason with the harvest nearly identical to Marion. Plant: trailing canes; thornlessness from Austin Thornless; healthy but less vigorous than Marion; productive, comparable yield to Marion; well suited to machine harvest; not particularly susceptible to Septoria leaf spot and purple blotch; no vegetative or fruit symptoms of cane or leaf rust; no significant winter injury has been experienced but hardiness has not been well tested; has survived $-8{ }^{\circ} \mathrm{C}$ in northern Washington while Marion was severely damaged; ploidy, $2 n=9 x=63$ as estimated by flow cytometry.

Clark Gold. A thorny, trailing blackberry with yellow fruit. Origin: Jackson County, Tex., by John William Clark. Spontaneous mutation of the southern dewberry, Rubus trivialis. USPP 14,935, issued 22 June 2004. Fruit: yellow (lacking anthocyanin pigments); medium-small, $3.7 \mathrm{~g}$; blocky-ovoid, occasionally spheroid; $8.7 \% \mathrm{SS}$; flavor sweet and similar to $R$. trivialis; seed wt. $2.4 \mathrm{mg}$; ripens very early, $19 \mathrm{Apr}$. in Jackson County, Texas and 10-15 d before Brazos. Plant: trailing; thorny with glandular hairs; canes are green and lack red coloration of normal Rubus trivialis; flowers have increased petal number compared to $R$. trivialis, up to $15 /$ flower; ploidy assumed to be $2 \mathrm{n}=2 \mathrm{x}=14$ based on $R$. trivialis parentage.

Driscoll Carmel. An early-mid season, thorny, semi-erect blackberry. Origin: developed by Carlos D. Fear, Gavin Sills, Fred M. Cook, and Richard E. Harrison, Driscoll Strawberry Associates, Inc., Watsonville, Calif. BY45.1 x BY63.2; cross made in 1996. USPP 15,058 issued 3 Aug. 2004, assigned to Driscoll Strawberry Associates, Inc. Fruit: solid black; medium-large, 6.2 g; firm; ovate; glossy; $11.9 \%$ SS; early-mid harvest season; Plant: semi-erect; thorny; high productivity; low-chill requirement; ploidy assumed to be $2 \mathrm{n}=4 \mathrm{x}=28$.

Driscoll Cowles. A late season, thornless, semi-erect blackberry. Origin: developed by Carlos D. Fear, Gavin Sills, Fred M. Cook, and Richard E. Harrison, Driscoll Strawberry Associates, Inc., Watsonville, Calif. 
Driscoll Sonoma x Loch Ness; cross made in 1993. USPP 14,780 issued 11 May 2004, assigned to Driscoll Strawberry Associates, Inc. Fruit: solid black; medium-large, $6.1 \mathrm{~g}$; firm; narrow ovate; glossy; $11.2 \% \mathrm{SS}$; mid-late harvest season; Plant: semi-erect; thornlessness originally from Merton Thornless; moderately productive; high vigor; ploidy assumed to be $2 n=4 x=28$.

Driscoll Eureka. An early season, thorny, semi-erect blackberry. Origin: developed by Carlos D Fear, Gavin Sills, Fred M. Cook, and Richard E. Harrison, Driscoll Strawberry Associates, Inc., Watsonville, Calif. Zorro x BY45.1; cross made in 1996. USPP 14,765 issued 4 May 2004, assigned to Driscoll Strawberry Associates, Inc. Fruit: solid black; medium, 4.2 g; firm; ovate; glossy; 11.9\% SS; early harvest season; Plant: semi-erect; thorny; moderately productive; low-chill requirement; ploidy assumed to be $2 n=4 x=28$.

Driscoll Sonoma. A mid-late season, thornless, semi-erect blackberry. Origin: developed by Carlos D. Fear, Driscoll Strawberry Associates, Inc., Watsonville, Calif. Navaho x Hull Thornless; cross made in 1991. USPP 14,682 issued 6 Apr. 2004; assigned to Driscoll Strawberry Associates, Inc. Fruit: solid black; medium, 3.6 g; medium firmness; ovate to elliptic; medium glossiness; $12.0 \% \mathrm{SS}$; mid-late harvest season; Plant: semi-erect; thornlessness originally from Merton Thornless; moderately productive; low to moderate vigor; ploidy assumed to be $2 \mathrm{n}=4 \mathrm{x}=28$.

Loch Tay. A thornfree, semi-erect blackberry. Origin: Scottish Crop Research Institute, Invergowrie, Scotland, by Derek Jennings and Ronnie J. McNicol. Loch Ness X SCRI 82417D; cross made in 1986; selected in 1990; tested as SCRI 86510L-2; introd. in 2003. Fruit: medium, 5 g; firm; slightly conical; glossy; sweet blackberry flavor, superior to Loch Ness; postharvest evaluations comparable to Loch Ness; even drupelet set; ripens on average 25 July in Scotland, $\sim 21$ d before Loch Ness; Plant: semi-erect; thornlessness originally from Merton Thornless; productive, exceeding yield of Loch Ness; moderate vigor; hardiness not well tested; susceptible to anthracnose (Elsinoë veneta); susceptible to purple blotch; susceptible to cane and leaf rust; ploidy assumed to be $2 n=4 x=28$.

Metolius. An extremely early ripening trailing blackberry with excellent shipping and fresh-market characteristics. Origin: U.S. Dept. of Agriculture-Agricultural Research Service in Corvallis, Ore., by Chad E. Finn, Brian M. Yorgey, Bernadine C. Strik, and Robert R. Martin. Douglass X Kotata; cross made in 1994; selected in 1997; tested as ORUS 1452-1; introd. in 2005. Fruit: medium, $5.6 \mathrm{~g}$; attractive and glossy; conical with a very uniform drupelet arrangement; excellent firmness; very good flavor; can be picked firm black with good flavor; ripens with Obsidian blackberry and Willamette red raspberry, peaking 4-5 d ahead of Siskiyou and 2 to 4 weeks earlier than all erect and semi-erect blackberries; machine harvests well. Plant: trailing canes; very thorny; less vigorous than Obsidian and Marion; very stiff laterals that present fruit well for hand picking but can break during machine harvest, similar yield to Marion in Oregon but less in Washington; machine harvests well; not particularly susceptible to Septoria leaf spot and purple blotch; no vegetative or fruit symptoms of cane or leaf rust; no significant winter injury has been experienced but hardiness has not been well tested; has survived $-8{ }^{\circ} \mathrm{C}$ in northern Washington while Marion was severely damaged; ploidy is unknown and difficult to predict as Douglass is $8 \mathrm{x}$ and Kotata is $7 \mathrm{x}$.

Nightfall. A thornless, trailing blackberry, that can be machine harvested with excellent processing quality. Origin: U.S. Dept. of AgricultureAgricultural Research Service in Corvallis, Ore., by ChadE. Finn, Brian M. Yorgey, Bernadine C. Strik, and Robert R. Martin. Marion x Waldo; cross made in 1993; selected in 1996; tested as ORUS 1486-2; introd. in 2005. Fruit: medium, $6.2 \mathrm{~g}$; conic with a more uniform drupelet arrangement than Marion; medium firmness, firmer than Marion; excellent machine harvest fruit quality; as an IQF fruit ranked similar to Marion for color, seediness, appearance, overall quality, but poorer for flavor; as a puree, ranked similar to Marion for aroma, flavor, color, and overall quality and lower for flavor; very good flavor but tart; ripens in midseason with the harvest season identical to Marion in Oregon and two days later in Washington. Plant: trailing canes; thornlessness originally from Austin Thornless; vigorous, similar to Marion; very productive, comparable to or greater than Marion; ripens in midseason, nearly identical to Marion; well suited to machine harvest; not particularly susceptible to Septoria leaf spot and purple blotch; no vegetative or fruit symptoms of cane or leaf rust; no significant winter injury has been experienced on this genotype in Oregon, however in northern Washington when temperatures dropped to $-8{ }^{\circ} \mathrm{C}$ it and Marion were severely damaged; ploidy presumed to be $2 n=6 x=42$ based on parentage.

Obsidian. An extremely early ripening trailing blackberry with excellent shipping and fresh-market characteristics. Origin: U.S. Dept. of Agriculture-Agricultural Research Service in Corvallis, Ore., by Chad E. Finn, Brian M. Yorgey, Bernadine C. Strik, Robert R. Martin, and Chaim Kempler. ORUS 828-43 x ORUS 1122-1; cross made in 1993; selected in 1995; tested as ORUS 1369-3; introd. in 2005. Fruit: medium-large, 6.8 g; glossy; blunt conic; drupelet arrangement, not as uniform as Siskiyou or as lumpy as Chester Thornless; very good firmness; excellent flavor; can be picked firm black with good flavor; in commercial fresh storage trials still firm after $22 \mathrm{~d}$ refrigeration with minimal mold and fair flavor; excellent black color going into and coming out of refrigerated storage and through freezing and thawing; soluble solids similar to Marion and much greater than Chester Thornless; titratable acidity was greater than for Chester Thornless and similar to Marion; ripens with Metolius blackberry and Willamette red raspberry, peaking 4-5 d ahead of Siskiyou and 2 to 4 weeks earlier than all erect and semi-erect blackberries; machine harvests well. Plant: trailing canes; thorny; vigorous, more vigorous than Marion; very productive, greater than all other current trailing cultivars; not particularly susceptible to Septoria leaf spot and purple blotch; no vegetative or fruit symptoms of cane or leaf rust; no significant winter injury has been experienced on this genotype in Oregon, Washington or British Columbia, however it has not been exposed to temperatures lower than $-11.3{ }^{\circ} \mathrm{C}$; ploidy estimated to be $2 n=6 x=42$ based on flow cytometry.

Prime-Jan ${ }^{\mathrm{TM}}$ (cv.APF-8). A thorny, erect primocane-fruiting blackberry. Origin: Univ. of Arkansas, by John R. Clark, James N. Moore, and Jose Lopez-Medina. Ark 1836 x Arapaho; cross made 1994; selected in 1997; tested as APF-8; introd. in 2004. USPP 15,788, issued 7 June 2005. Fruit: medium, $5.0 \mathrm{~g}$ floricane fruit average and primocane fruit ranging from $4.0 \mathrm{~g}$ (Arkansas) to $10 \mathrm{~g}$ (Oregon); glossy, blocky and conical; moderate to good firmness; good flavor similar to other Arkansas thorny cultivars; $9.6 \% \mathrm{SS}$; dry seed weight $3.2 \mathrm{mg}$; postharvest handling better than Prime-Jim ${ }^{\mathrm{TM}}$ but not intended for shipping; floricane fruit first ripe date in Arkansas 10 June; primocane fruit first ripe date 18 July in Arkansas and about 1 Sept. in Oregon; primocane crop can extend until frost. Plant: erect canes; thorny; moderate vigor; floricane productivity moderate but has been reduced from spring freezes more so than Prime$\mathrm{Jim}^{\mathrm{TM}}$; primocane yield low to high depending on location; susceptible to double blossom/rosette (Cercosporella rubi)(floricanes); moderately resistant to anthracnose; ploidy assumed to be $2 n=4 x=28$.

Prime-Jim $^{\mathrm{TM}}$ (cv. APF-12). A thorny, erect primocane-fruiting blackberry. Origin: Univ. of Arkansas, by John R. Clark, James N. Moore, and Jose Lopez-Medina. Arapaho x Ark. 830; cross made 1994; selected in 1997; tested as APF-12; introd. in 2004. USPP pending. Fruit: medium, $4.9 \mathrm{~g}$ floricane fruit average and primocane fruit ranging from 3.3 (Arkansas) to $10 \mathrm{~g}$ (Oregon); glossy, blocky and conical; moderate firmness; good flavor similar to other Arkansas thorny cultivars; $7.9 \%$ SS; dry seed weight $2.1 \mathrm{mg}$; postharvest handling similar to Choctaw and not intended for shipping; floricane fruit first ripe date in Arkansas 7 June near Arapaho; primocane fruit first ripe date 17 July in Arkansas and about 1 Sept. in Oregon; primocane crop can extend until frost. Plant: erect canes; thorny; moderate vigor; floricane productivity moderate to 
high; primocane yield low to high depending on location; susceptible to double blossom/rosette (floricanes); moderately resistant to anthracnose; ploidy assumed to be $2 n=4 x=28$.

Xavante. A thornless, erect, low-chill blackberry. Origin: Embrapa Clima Temperado, Pelotas, Brazil and the Univ. of Arkansas by Maria do C. Bassols Raseira, James N. Moore, Alverides M. dos Santos, John R. Clark and Luis E. C. Antunes. Open pollination of population 9303 that was a cross of A-1629 and A-1507 of which seeds were collected in Arkansas and brought to Brazil in 1994; selected in 1996; tested as Selection 3/96; introd. in 2003. Fruit: medium, 5.7-6.1 g; medium-firm; glossy; $6.5 \%$ to $8 \%$ SS; ripens by December (in Southern Brazil), a few days earlier than Tupy. Plant: erect; thornlessness originally from Merton Thornless; blooms from September to October; vigorous; productive; low-chill requirement estimated to be less than $250 \mathrm{~h}$; ploidy assumed to be $2 \mathrm{n}=4 \mathrm{x}=28$.

\section{BLUEBERRY}

\section{Paul Lyrene}

Horticultural Sciences Dept., Univ. of Florida, Gainesville

Abundance. A vigorous, low-chill highbush blueberry. Origin: Univ. of Florida, by Paul Lyrene. FL 93-70 x FL 90-4; cross made in 1993; selected in 1995; tested as FL 98-358; introd. in 2006. USPP pending. Fruit: large, up to $3.1 \mathrm{~g}$; good firmness; medium blue; small, dry scar; sweet; 50\% ripe about May 3 in north Florida. Plant: vigorous, upright, chill requirement $300 \mathrm{~h}$; makes numerous flower buds and sets fruit easily when cross pollinated.

ARS 96-138. A hexaploid blueberry germplasm release with bright pink fruit. Origin: USDA-ARS, Chatsworth, N. J., by Mark Ehlenfeldt. NJ 89-158-1 x Vaccinium ashei cv. Delite; cross made in 1991; selected in 1996; subsequently evaluated at Chatsworth by Ehlenfeldt and at USDA-ARS in Corvallis, Ore., by Chad Finn; introd. 2005. Fruit: size medium; glossy bright pink color; good firmness; mild pleasant flavor; ripens mid-late to late season. Plant: vigorous, upright, full; leaves glossy green; in New Jersey, it flowers with southern blueberry germplasm and often has reduced yields due to spring frosts; probably best adapted where rabbiteye blueberries are grown; cross pollination recommended.

Camellia. An early to midseason ripening southern highbush blueberry. Origin: Univ. of Georgia and USDA-ARS, by D. Scott NeSmith and Arlen Draper. MS-122 x MS-6; selected in 1996; tested as TH-621; introduced in 2005. USPP pending. Fruit: large, 1.8 to $2.0 \mathrm{~g}$; very light blue color; small, dry picking scar; good firmness and excellent flavor; ripens a few days after Star, but before O'Neal. Plant: highly vigorous, strong cane growth; open, spreading bush habit and narrow crown; flowers 5 to $8 \mathrm{~d}$ after Star and O'Neal in south Georgia; yield similar to Star but exceeds O'Neal; estimated chill hour requirement 450 to $500 \mathrm{~h}$; suitable for fresh-market; propagation moderately easy from softwood cuttings; plants somewhat self-fertile but should be planted with other southern highbush cultivars with a similar time of bloom for cross-pollination.

DeSoto. A semi-dwarf rabbiteye blueberry adapted to the Gulf Coast and Southeastern U.S. Origin: USDA-ARS Small Fruit Research Station, Poplarville, MS, by S.J. Stringer, J.M. Spiers, and A.D. Draper. T-110 x T-107; cross made in early 1970s at Beltsville, Md.; selected in 1976, tested as MS-63; introd. in 2004. Fruit: medium-large; medium-light blue; scar and firmness good, flavor excellent; ripens $\sim 14 \mathrm{~d}$ later than Tifblue, over a 6-week period or longer; berry clusters: medium-loose. Plant: semi-dwarf, moderately spreading, medium vigor; flowers $\sim 21$ $\mathrm{d}$ after Climax, providing insurance against late spring frosts; medium -high yield potential; propagation by softwood or hardwood cuttings.
Dixieblue. A vigorous, southern highbush blueberry adapted to the Coastal Plains and Gulf Coast regions of the U.S. Origin: USDA-ARS Small Fruit Research Station, Poplarville, MS, by S.J. Stringer, J.M. Spiers, and A.D. Draper. G-144 x US 75; cross made in mid 1970s at Beltsville, Md.; selected in 1979 and tested as MS-111; introd. in 2005. Fruit: medium-large, flat, good color, firmness, flavor and picking scar; ripens $\sim 10 \mathrm{~d}$ before Climax. Plant: vigorous, moderately spreading, round in shape and medium in height; flowering: $\sim 7 \mathrm{~d}$ after Climax; medium-high yield potential; propagation by softwood or hardwood cuttings; should be interplanted with other southern highbush cultivars to optimize earliness, yield and quality.

Florida Rose. A rabbiteye blueberry cultivar with bright pink fruit. Origin: Univ. of Florida, by Paul Lyrene. FL 94-88 x FL 94-81; cross made in 1994; selected in 1996; tested as FL 98-449; introd. 2004. USPP 14,485. Fruit: medium size, $1.5 \mathrm{~g}$; ripe color bright red to pink where exposed to sun, light pink to dark pink where shaded; scar good; firmness good; flavor sweet without much acid. Plant: vigorous rabbiteye-type growth; chill requirement $300 \mathrm{~h}$; makes numerous flower buds; flowers with Brightwell and ripens with Climax; sets fruit well when cross-pollinated.

G-435. A dark pink fruited highbush blueberry germplasm release. Origin: USDA-ARS, Chatsworth, N. J., by Mark Ehlenfeldt. G-132 x 290-1; cross made at Beltsville, Md.; selected in 1978 in New Jersey by Arlen Draper; evaluated in New Jersey and in Grand Junction, Michigan; introd. 2005. Fruit: size medium, $1.3 \mathrm{~g}$; color dark pink; scar good; firmness good; flavor good; early to midseason ripening. Plant: upright and typical of highbush; moderate to good yield; has some southern ancestry and has had some flower bud hardiness problems in New Jersey.

Gupton. A vigorous southern highbush blueberry adapted to the Coastal Plains and Gulf Coast regions of the U.S. Origin: USDA-ARS Small Fruit Research Station, Poplarville, Miss., by J.M. Spiers, S.J. Stringer, and A.D. Draper. MS-122 x MS-6; cross made in mid 1980s at Beltsville, Md.; selected in 1991 and tested as MS 548; introd. in 2005. Fruit: medium-large; color, firmness, flavor and picking scar good; ripens $\sim 10 \mathrm{~d}$ before Climax. Plant: vigorous, upright; medium-high yield potential; propagation by softwood or hardwood cuttings; should be interplanted with other southern highbush cultivars to optimize earliness, yield and quality.

Native Blue. An ornamental evergreen blueberry ( $V$. darrowi) to complement azaleas, camellias, crepe myrtles, etc. in landscape settings or for basket culture, especially adapted to the southeastern U.S. Origin: USDA-ARS Small Fruit Research Station, Poplarville, Miss., by J.M. Spiers, S.J. Stringer, and A.D. Draper. Florida 4B x US 799; cross made in early 1990s at Beltsville, Md.; selected in 1994 and tested as MS-611; introd. in 2004. Fruit: small, dark, semi-sweet, flavorful. Plant: low growing, compact, finely branched, hardy, vigorous; foliage evergreen, glaucous with small delicate leaves; new leaf flushes with light pinkish hues that change to bluish green; propagates readily by softwood and hardwood cuttings.

Novablue. A seed-propagated lowbush blueberry ( $V$. angustifolium). Origin: Agriculture and Agri-Food Canada, Atlantic Food and Horticulture Research Centre, Kentville, Nova Scotia, by Andrew R. Jamieson. Fundy x Brunswick; cross made in 1989 and its seedlings tested as KBF7 against 41 other seedling populations from 1990-2004; introduced in 2006. Fruit: large, 0.3-0.6 g compared to wild lowbush; light powdery blue; good firmness and scar; less productive than Fundy but more productive than open-pollinated seedlings; flavor is very good. Plant: similar morphologically to parents but since they are seed propagated they produce many more rhizomes than do cuttingpropagated Fundy and Brunswick; sprouts (new shoots after a pruning) are unbranched or have few branches, a trait that facilitates mechanical harvesting; pollinizer not required. 
Palmetto. An early ripening southern highbush blueberry. Origin: Univ. of Georgia and USDA-ARS, by D. Scott NeSmith and Arlen Draper. US $158 \times$ TH-157; selected in 1985; tested as TH-471; introduced in 2003. USPP pending. Fruit: medium size, 1.2 to $1.4 \mathrm{~g}$; medium blue color; small, dry picking scar; excellent firmness and flavor; ripens with Star, but before Georgiagem and O'Neal; concentrated ripening. Plant: moderately vigorous; open, spreading bush habit and narrow crown; flowers in early March in south Georgia and will likely benefit from frost protection (similar to Star); somewhat self-fertile but should be planted with other southern highbush cultivars with similar bloom time for cross-pollination; yield substantially exceeds Georgiagem; estimated chill hour requirement 350 to $450 \mathrm{~h}$; suitable for fresh market; propagates readily from softwood cuttings.

Rebel. A very early season southern highbush blueberry. Origin: Univ. of Georgia, by D. Scott NeSmith. FL 92-84 open pollinated; selected in 2000; tested as TH-642; introduced in 2006. USPP pending. Fruit: large, 1.9 to $2.5 \mathrm{~g}$; medium light blue color; small, dry picking scar; excellent firmness; average flavor; ripens 6 to $9 \mathrm{~d}$ before Star in south and middle Georgia. Plant: highly vigorous, very precocious; spreading bush habit with medium crown; flowers 3 to $4 \mathrm{~d}$ before Star in south and middle Georgia; yield similar to or greater than Star in south Georgia; partially self-fertile but should be planted with other southern highbush cultivars with similar bloom time for cross-pollination; excellent leafing, even following mild winters; estimated chill hour requirement 400 to $450 \mathrm{~h}$; suitable for fresh market; propagates very easily from softwood cuttings.

Savory. An early ripening rabbiteye blueberry. Origin: Univ. of Florida, by Paul Lyrene. Exact parentage unknown; cross made in 1981; selected in 1984; tested as "Early Brightwell"; introd. 2004. USPP 15,109. Fruit: large, up to $2.0 \mathrm{~g}$; color light blue; scar good; firmness good; flavor sweet; ripens 7 to $10 \mathrm{~d}$ before Climax in southeast Georgia. Plant: vigorous, upright, chill requirement 300 h; flowers with Climax; needs crosspollination; makes numerous flower buds and requires winter pruning.

Springhigh. A vigorous, early ripening low-chill highbush blueberry. Origin: Univ. of Florida, by Paul Lyrene. FL 91-226 x Southmoon; cross made in 1993; selected in 1995; tested as FL 96-96; introd. in 2006. USPP applied for. Fruit: size very large; color dark blue; scar good; firmness good; flavor sweet; ripens $9 \mathrm{~d}$ before Star. Plant: vigorous, very upright, excellent survival in the field; chill requirement $200 \mathrm{~h}$; date of $50 \%$ open flower 16 Feb. in north Florida; sets fruit very easily when cross pollinated; at least partially self fruitful.

Springwide. A low-chill highbush blueberry. Origin: Univ. of Florida, by Paul Lyrene. FL 83-132 x Sharpblue; cross made in 1984; selected in 1986; tested as FL 90-91; introd. in 2006. USPP pending. Fruit: large, up to $3 \mathrm{~g}$; color medium blue; good scar, firmness, and flavor; $50 \%$ ripe 5 d before Star (about 25 Apr. in northeast Florida). Plant: vigorous, somewhat spreading; chill requirement 200 h; not self-fruitful; leafs strongly during flowering.

Vernon. An early ripening, high-yielding rabbiteye blueberry cultivar. Origin: Univ. of Georgia and USDA-ARS, by D. Scott NeSmith and Arlen Draper. T-23 x T-260; selected in 1990; tested as T-584; introduced in 2004. USPP pending. Fruit: large, $1.8 \mathrm{~g}$; medium to light blue color; medium, dry picking scar; excellent firmness; good flavor; ripens with Alapaha, Climax, and Premier. Plant: vigorous, numerous canes arising from crown; upright; high yielding, exceeding Climax and Premier in south Georgia; flowers 7 to $10 \mathrm{~d}$ after Climax in south Georgia; estimated chill requirement 500-550 h; somewhat self fertile, similar to Brightwell, but should be planted with other rabbiteye cultivars with similar time of bloom for cross-pollination; suitable for fresh market, likely machine harvestable; propagates readily from softwood cuttings.

\section{BLUE HONEYSUCKLE}

Kim Hummer

USDA-ARS National Clonal Germplasm Repository

Corvallis, Ore.

Amfora. (translation $=$ amphora) Midseason, large fruited, blue honeysuckle released for northern and northwestern Russia. Origin: N.I. Vavilov Institute of Plant Industry, Pavlov Experiment Station, in St. Petersburg, Russia, by Maria N. Plekhanova. Roksana open pollinated; introd. in 1997. Fruit: midseason ripening, about 22 June in St. Petersburg; 1.0-1.2 g berry; ascorbic acid 59 mg/100 g; $7.2 \%$ SS. Plant: medium yielding, 1.0 to $2.1 \mathrm{~kg} / \mathrm{bush}$.

Berry Blue ${ }^{\circledR}$ (cv. Czech No. 17). Tall blue honeysuckle. Origin: Czech Republic by a private nurseryman. Selection of L caerulea var. kamtschatica. Fruit: large fruit. Plant: medium yield; not self fertile; vigorous, productive plant with upright growth habit to $2.4 \mathrm{~m}$ tall; winter hardy to $-40{ }^{\circ} \mathrm{C}$.

Blue Belle ${ }^{\circledR}$ (cv. Tomichka). (translation = one from Tomsk). Early blooming blue honeysuckle. Origin: Bakcharskii Agricultural Station of the M.A. Lisavenko Siberian Horticultural Research Institute, Tomsk, Russia, by I.K. Gidzuk andZ.I. Luchnik. Delfin (=Dolfin) open pollinated; introd. in 1987. Fruit: early-midseason ripening, good tasting; medium size, $0.9 \mathrm{~g}$; ascorbic acid content $46 \mathrm{mg} / 100 \mathrm{~g}$; $7.5 \% \mathrm{SS}$; taste is soursweet. Plant: medium yielding, 1.8 to $2.5 \mathrm{~kg} / \mathrm{bush}$; grows to $1.5 \mathrm{~m}$ tall; cross pollination needed; harder to propagate than other cultivars.

Blue Bird ${ }^{\circledR}$ (cv. Sinyaya Pititsin). (translation = blue bird). One of the three earliest Russian blue honeysuckle releases. Origin: Bakcharskii Agricultural Station of the M.A. Lisavenko Siberian Horticultural Research Institute, Tomsk, Russia, by Z.P. Jolobova, I.P. Kalinina, and Z.I. Luchnik. Start open pollinated; selected in 1973; introduced in 1980. Fruit: early-season ripening. Medium size 0.79 to $0.87 \mathrm{~g}$; ascorbic acid content $72 \mathrm{mg} / 100 \mathrm{~g} ; 6.4 \%$ SS. Plant: Medium yielding, 1.0 to $2.0 \mathrm{~kg} / \mathrm{bush}$.

Blue Forest ${ }^{\circledR}$ (cv. Magadan). Midseason ripening blue honeysuckle. Origin: N.I. Vavilov Institute of Plant Industry, Far East Experiment Station, Vladivostok, Russia, by N.M. Bochkarnikova. Selection 56/17 of L. caerulea from Magadan Territory; introd. in 1968. Fruit: dark blue; soft; medium size but uneven, $0.9 \mathrm{~g}$ berry; ascorbic acid content $73.6 \mathrm{mg} / 100 \mathrm{~g} ; 6.9 \% \mathrm{SS}$; midseason ripening. Plant: large deep green foliage; to $\sim 0.9 \mathrm{~m}$ tall; medium yield.

Blue Lightning $®$ (cv.Zarnitsa). (translation = lightning). Early ripening, large fruited blue honeysuckle. Origin: N.I. Vavilov Institute of Plant Industry, Far East Experiment Station, Vladivostok, Russia, by N.M. Bochkarnikova and A. Sabitov. Best F1 selection of L. caerulea var. edulis collected from Dalnegorskii Region of the Primorsky Territory; introd. in 2000. Fruit: early ripening but uneven, medium size, $1.0 \mathrm{~g}$; ascorbic acid content 49 to $79 \mathrm{mg} / 100 \mathrm{~g}$; 6.0 to $6.8 \%$ SS. Plant: floppy branch growth; medium yielding, $2.4 \mathrm{~g} / \mathrm{bush}$; grows to $\sim 1.5 \mathrm{~m}$ tall.

Blue Moon ${ }^{\circledR}$ (cv. Sergei). Late blooming and late ripening blue honeysuckle. Origin: USSR Botanical Garden Kiev, Ukraine. Seedling of $L$. caerulea from Moneron, Iturup, or Kunashir Island. Fruit: late ripening; $1.2 \mathrm{~g}$ berry; very acid fruit. Plant: medium yield.

Blue Nova ${ }^{\circledR}$ (cv. Novinka). translation = novelty). Midseason ripening, compact blue honeysuckle. Origin: N.I. Vavilov Institute of Plant Industry, Far East Experiment Station, Vladivostok, Russia, by N.M. Bochkarnikova. Introd. in1975. Fruit: midseason ripening; medium size, $0.9 \mathrm{~g}$; ascorbic acid content $58.1 \mathrm{mg} / 100 \mathrm{~g} ; 4.8 \%$ SS. Plant: medium yield, $3.2 \mathrm{~kg} / \mathrm{bush}$; compact shrub to $1.2 \mathrm{~m}$ tall; cross-pollination needed. 
Blue Pacific $®$ (cv. F-1-9-58). Late flowering and late ripening blue honeysuckle. Origin: U.S.S.R. Botanical Garden, Kiev, Russia. Selection of $L$. caerulea from Kurile Islands. Fruit: large, dark blue with consistently good yield in North America, particularly west of the Cascade Mountains in the Pacific Northwest. Plant: late ripening, grows to $\sim 0.9 \mathrm{~m}$ tall; cross pollination needed; hardy to $-40{ }^{\circ} \mathrm{C}$; precocious bearing 1-2 years after planting.

Blue Sky® (cv. Valery No. 2). Early blooming blue honeysuckle. Origin: private gardener in Irkutsk, Russia. Selection of $L$. caerulea var. kamtschatica. Fruit: midseason ripening. Plant: compact shrub to $0.9 \mathrm{~m}$ in height; medium yield; cross-pollination needed.

Blue Velvet@ (cv. Kiev No. 8). Late blooming and late ripening, blue honeysuckle. Origin: USSR Botanical Garden, Kiev, Ukraine. Selection of $L$. caerulea from Monero, Iturup or Kunashir Islands. Fruit: large; sweet-tart flavor. Plant: grey-green pubescent foliage; compact spreading shrub, 0.9-1.2 $\mathrm{m}$ tall and $\sim 1.2 \mathrm{~m}$ wide; blooms late; cold hardy but survives well in Pacific Maritime climates. Note: Blue Velvet ${ }^{\mathrm{TM}}$ Honeysuckle is associated with an ornamental selection of $L$. korolkowii first used by Colorado State Univ. in 1999.

Czech No. 17. See Berry Blue®.

Desertnaya. (translation $=$ dessert) A mid-late season ripening honeysuckle with medium sized-berries and high vitamin $\mathrm{C}$ that is adapted for northwestern Russia. Origin: N.I. Vavilov Institute of Plant Industry, Pavlov Experiment Station, St. Petersburg, Russia, by F.K. Teterev and Z.A. Koroleva. $F_{2}$ seedling of L. caerulea obtained from Petropavlovsk-Kamchatski City, Russia; selected in 1973; introd. by Maria N. Plekhanova in 1987. Fruit: mid-late season ripening, about 28 June in St. Petersburg; medium size, up to $0.94 \mathrm{~g}$; ascorbic acid content 94 mg/100 g. Plant: upright dense branches, medium yielding.

Dimka. See Smoky Blue ${ }^{\circledR}$.

F-1-9-58. See Blue Pacific $®$.

Fialka. (translation: violet, like the flower). Late ripening, large fruited, blue honeysuckle especially adapted for northern and northwestern Russia and the Ukraine. Origin: N.I. Vavilov Institute of Plant Industry, Pavlov Experiment Station, St. Petersburg, Russia, by Maria N. Plekhanova. Roksana open pollinated; selected in 1955; introd. in 1992. Fruit: medium size, up to $1.1 \mathrm{~g}$; ascorbic acid content $45 \mathrm{mg} / 100 \mathrm{~g}$; $8.4 \% \mathrm{SS}$; aromatic. Plant: medium yield.

George Bugnet. Heritage Canadian ornamental blue honeysuckle, also called "Sweetberry Honeysuckle," adapted to cold regions of Alberta. Origin: Agricultural Research Station, Beaverlodge, Alberta, Canada. Selection of Russian L. caerulea subsp. pallassii made in Canada; introd. in the 1920s; propagated by seed by Canadian nurseries. Fruit: small; bitter; poor quality. Plant: very cold hardy.

Goluboye Verenteno. (translation $=$ light or sky blue spindle). One of the three first Russian blue honeysuckle releases. Origin: M.A. Lisavenko Siberian Horticultural Research Institute, Tomsk, Russia, by Z.P. Jolobova, I.P. Kalinina, and Z.I. Luchnik. Start open pollinated; selected in 1973; introduced in 1980. Fruit: medium size, 0.87-0.93 g; ascorbic acid content $61 \mathrm{mg} / 100 \mathrm{~g} ; 6.4 \%$ SS. Plant: early ripening; medium yield, 1.5 to $2.0 \mathrm{~kg} / \mathrm{bush}$.

Ivushka. Early-midseason ripening, small fruited, blue honeysuckle adapted to the Russian Far East. Origin: N.I. Vavilov Institute of Plant Industry, Far East Experiment Station, Vladivostok, Russia, by N.M. Bochkarnikova. Selection of L. caerulea var. kamtschatica; introd. in 1975. Fruit: early season ripening; medium fruit, $0.9 \mathrm{~g}$; ascorbic acid content $76.5 \mathrm{mg} / 100 \mathrm{~g}, 5.9 \% \mathrm{SS}$; slightly bitter taste. Plant: medium yield, $3 \mathrm{~kg} /$ plant.
Julia Bugnet. Heritage Canadian ornamental blue honeysuckle, also called "Sweetberry Honeysuckle," Adapted to cold regions of Alberta. Origin: Agricultural Research Station, Beaverlodge, Alberta, Canada. Selection of Russian L. caerulea subsp. Pallassii made in Canada; introd. in the 1920s; propagated by seed by Canadian nurseries. Fruit: small; bitter; poor quality. Plant: very cold hardy.

Kapel. (translation $=$ thaw or dripping) . Early ripening blue honeysuckles with small fruit, adapted to the Russian Far East: Origin: N.I. Vavilov Institute of Plant Industry, Far East Experiment Station, Vladivostok, Russia, by N.M. Bochkarnikova. Selection of L. caerulea var. kamtschatica; introduced in 1978. Fruit: early ripening about 12 June in St. Petersburg; small size; ascorbic acid content 55 mg/100 g; 6.0\% SS. Plant: medium yielding $3 \mathrm{~kg} / \mathrm{bush}$.

Kiev No. 8. See Blue Velvet®.

Magadan. See Blue Forest $®$.

Morena. Midseason ripening blue honeysuckle with medium-sized fruit especially for northwestern Russia. Origin: N.I. Vavilov Institute of Plant Industry, Pavlov Experiment Station, St. Petersburg, Russia, by M.N. Plekhanova and A.V. Kondrikova. L. caerulea No. 101 (from vicinity of Petropavlovsk-Kamchatsk City) x L. caerulea No 21-5 (from Vladivostok); introd. in 1992. Fruit: early ripening about 19 June in St. Petersburg; medium-sized $1.1 \mathrm{~g}$; ascorbic acid content $54 \mathrm{mg} / 100$ g; $7.8 \%$ SS. Plant: medium yield, 1.2 to $2.4 \mathrm{~kg} / \mathrm{bush}$.

Nymfa. Mid-late season ripening, large-fruited blue honeysuckle that is well adapted to northwestern Russia. Origin: N.I. Vavilov Institute of Plant Industry, Pavlov Experiment Station, St. Petersburg, Russia, by Maria N. Plekhanova. $F_{3}$ of Leningradskii Velikan (translation=Leningrad Giant); introduced in 1993. Fruit: midseason-late; ripening about 21 June in St. Petersburg; large, $1.2 \mathrm{~g}$; ascorbic acid content $52 \mathrm{mg} / 100 \mathrm{~g}$; $8.8 \%$ SS; strong aroma. Plant: medium yield, 1.4 to $2.0 \mathrm{~kg} / \mathrm{bush}$.

Novinka. See Blue Nova®.

Pavlovskaya. Large fruited blue honeysuckle that is well adapted for northern and northwestern Russia. Origin: N.I. Vavilov Institute of Plant Industry, Pavlov Experiment Station, St. Petersburg, Russia, by F.K. Teterev and Z.A. Koroleva. $\mathrm{F}_{2}$ L. caerulea from PetropavlovskKamchatski City; selected in 1973; introduced by M.N. Plekhanova in 1987. Named for the experiment station. Fruit: midseason; large, 1.2 average with largest fruit $1.3 \mathrm{~g} /$; ascorbic acid content higher than most $69 \mathrm{mg} / 100 \mathrm{~g}$; sugar $7.8 \%$ SS. Plant: medium yield, $1.5 \mathrm{~kg} / \mathrm{bush}$.

Rassvet. $($ translation $=$ dawn). Early-midseason blue honeysuckle with medium-sized fruit and that is adapted to Russian Far East. Origin: N.I. Vavilov Institute of Plant Industry, Far East Experiment Station, Vladivostok, Russia, by N.M. Bochkarnikova and A. Sabitov. Selection of L. caerulea var. kamtschatica; introduced in 2000. Fruit: early season; medium, $0.9 \mathrm{~g}$; ascorbic acid content $78 \mathrm{mg} / 100 \mathrm{~g} ; 7.0 \%$ SS. Plant: high yield, $3.5 \mathrm{~kg} / \mathrm{bush}$.

Sinyaya Pititsa. See Blue Bird®.

Smokey Blue ${ }^{\circledR}$ (cv. Dimka). (translation = haze). Smoke-blue colored fruit. Origin: N.I. Vavilov Institute of Plant Industry, Far East Experiment Station, Vladivostok, Russia, by A. Sabitov. Selection of $L$. caerulea from Verkhne-bureinskii Region of the Khabaarovskii Territory; introduced 1988. Fruit: drop readily upon ripening; waxy white "bloom" on fruit skin. Plant: early blooming; midseason ripening; two or more genotypes needed for cross-pollination; precocious, bearing 1-2 years after planting; grows to $0.9 \mathrm{~m}$ tall; small shrub with spreading form.

Start. One of the three earliest Russian blue honeysuckle releases. Origin: M.A. Lisavenko Siberian Horticultural Research Institute, 
Tomsk, Russia, by Z.P. Jolobova, I.P. Kalinina and Z.I. Luchnik. Seedling No. 8. selection of wild material from Kamchatka Peninsula; introd. in 1980. Fruit: medium, $0.8 \mathrm{~g}$; ascorbic acid content 56 to 70.4 $\mathrm{mg} / 100 \mathrm{~g} ; 7.7 \% \mathrm{SS}$; aromatic. Plant: early ripening; low to medium yield, 0.6 to $1.0 \mathrm{~kg} / \mathrm{bush}$.

Tomichka. See Blue Belle®.

Valery No. 2. See Blue Sky®.

Viola. Early ripening blue honeysuckle that is well adapted to northern and northwestern Russia. Origin: N.I. Vavilov Institute of Plant Industry, Pavlov Experiment Station, St. Petersburg, Russia, by Maria N. Plekhanova. L. caerulea Saianskaia 317 x Leningradskii Velikan; introd. in 1995. Fruit: medium, to $1.0 \mathrm{~g}$; early ripening; ascorbic acid content $61 \mathrm{mg} / 100 \mathrm{~g} ; 6.8 \% \mathrm{SS}$; taste is sour-sweet with some bitterness. Plant: medium yield, $2.8 \mathrm{~kg} / \mathrm{bush}$.

Zarnitsa. See Blue Lightning®.

Zolushka. Early ripening blue honeysuckle. Origin: M.A. Lisavenko Siberian Horticultural Research Institute, Tomsk, Russia, by Z.P. Jolobova and I.P. Kalinina. Start open pollinated; introd. in 1991. Fruit: early ripening; size $0.7 \mathrm{~g}$; ascorbic acid content $51 \mathrm{mg} / 100 \mathrm{~g}$; $4.6 \%$ SS. Plant: medium yielding, 0.8 to $1.2 \mathrm{~kg} / \mathrm{bush}$.

\section{CHERRY ROOTSTOCK}

\section{Gregory A. Lang}

Horticulture Department, Michigan State Univ., East Lansing

GI@2091. Very dwarfing, precocity-inducing rootstock. Origin: Giessen, Germany, by Werner Gruppe and Hanna Schmidt, Justus Liebig Univ.. Prunus cerasus Schattenmorelle x Prunus canescens; cross made in 1969; tested as Gi 209-1; introd. in 2003. USPP 6,173 and assigned to Consortium Deutscher Baumschulen GmbH, Ellerbek, Germany. Plant: triploid; dwarfing rootstock for sweet and tart cherries; ungrafted tree is somewhat weeping, with many lateral branches; the root system is has more fine roots and fewer strong roots that Gisela®5 or Gisela®6. grafted mature tree size is $\sim 25 \%$ to $40 \%$ compared to F12/1 Mazzard; tree support is recommended; induces early fruiting of sweet cherry scions compared to Mazzard; nonsuckering and no known sensitivities to pollen-borne viruses; propagation by softwood cuttings.

Gisela®3. See GI®2091.

Krymsk®5(cv.VSL-2). Dwarfing to semi-dwarfing, precocity-inducing rootstock. Origin: at Krymsk, Russia, by Gennady Eremin. Prunus fruticosa $\times$ (P. serrulata var. lannesiana); cross made in 1976, selected in 1986; tested as VSL-2; introd. in 2002. USPP 15,723 and assigned to Varieties International LLC, Dundee, Ore. Plant: dwarfing to semidwarfing rootstock for sweet cherries. Rootstock Performance: grafted mature tree size is $~ 50 \%$ to $60 \%$ compared to Mazzard seedling; induces early fruiting of sweet cherry scions compared to Mazzard; nonsuckering; resistant to powdery mildew (Podosphaera clandestina); propagation by softwood cuttings, stoolbeds, or meristem cuttings in vitro.

Krymsk@6 (cv. LC-52). Semi-dwarfing, precocity-inducing rootstock. Origin: Krymsk, Russia, by Gennady Eremin. Prunus cerasus x (P. cerasus X P. maackii); cross made in 1964, selected in 1974; tested as LC-52; introd. in 2002. USPP 6,114 and assigned to Varieties International LLC, Dundee, Ore. Plant: semi-dwarfing rootstock for sweet cherries. Rootstock Performance: grafted mature tree size is $~ 60 \%$ to $70 \%$ compared to Mazzard seedling; induces early fruiting of sweet cherry scions compared to Mazzard; propagation by softwood cuttings or meristem cuttings in vitro.
LC-52. See Krymsk®6.

Myrobalan RI-1. Dwarfing, precocity-inducing, cross-species compatible interstock. Origin: Modesto, Calif., by Floyd Zaiger, Gary N. Zaiger, Leith M. Gardner, and Grant G. Zaiger. Prunus cerasifera open pollinated; introd. in 2001. USPP 14,126. Plant: can be used as an interstock for sweet cherries on various Prunus species or interspecific hybrids, including some for which direct grafting to sweet cherry would result in incompatible graft unions; grafted mature tree size can be reduced by shortening the length of the interstock. Rootstock performance: induces early fruiting of sweet cherry scions when used as an interstock on Citation ${ }^{\circledR}(P$. salicina $\times$ P. persica) compared to Mazzard; propagation by budding to desired rootstocks.

PiKuß1. Semi-dwarfing, precocity-inducing, productive rootstock. Origin: at Pillnitz, Germany, by Brigitte Wolfram. Prunus avium $\mathrm{x}(P$. canescens $\times$ P. tomentosa); cross made in 1972; tested as $\mathrm{Pi}-\mathrm{Ku} 4.20$; introd. in 2002. USPP 14,737 and assigned to Consortium Deutscher Baumschulen GmbH, Ellerbek, Germany. Plant: semi-dwarfing rootstock for sweet cherries; ungrafted tree upright and broad. Rootstock performance: grafted mature tree size is $70 \%$ compared to Mazzard seedling; induces early fruiting of sweet cherry scions compared to Mazzard; very good productivity; tolerant to Cytospora and low winter temperatures; propagation by softwood cuttings or meristem cuttings in vitro.

PiKuß3. Semi-vigorous, productive rootstock. Origin: at Pillnitz, Germany, by Brigitte Wolfram. Prunus pseudocerasus $\mathrm{x}$ (P. canescens X P. incisa); cross made in 1972; tested as Pi-Ku 4.83; introd. in 2002. USPP 15,508 and assigned to Consortium Deutscher Baumschulen $\mathrm{GmbH}$, Ellerbek, Germany. Plant: semi-vigorous rootstock for sweet cherries; good adaptation to various soils; well-anchored, with a few suckers; ungrafted tree is upright and pyramidal. Rootstock performance: grafted mature tree size is $\sim 80 \%$ compared to Mazzard seedling; induces slightly earlier fruiting of sweet cherry scions compared to Mazzard; good productivity; tolerant to Cytospora; moderately susceptible to low winter temperatures; propagation by softwood cuttings or meristem cuttings in vitro.

PiKu®4. Semi-dwarfing, precocity-inducing, productive rootstock. Origin: at Pillnitz, Germany, by Brigitte Wolfram. Prunus cerasus Schattenmorelle $\mathrm{X}$ (P. nipponica var. kurilensis $\mathrm{X} P$. sargentii); cross made in 1976; tested as Pi-Ku 1.10; introd. in 2002. USPP 15,650 and assigned to Consortium Deutscher Baumschulen GmbH, Ellerbek, Germany. Plant: semi-dwarfing rootstock for sweet cherries; Good adaptation to sandy soils and low natural precipitation; well-anchored, with a few suckers; ungrafted tree is bushy and drooping. Rootstock performance: grafted mature tree size is $\sim 60 \%$ to $70 \%$ compared to Mazzard seedling; induces early fruiting of sweet cherry scions compared to Mazzard; very good productivity; tolerant to Cytospora and low winter temperatures; propagation by softwood cuttings.

UCMH 55. Productive, Phytophthora-tolerant rootstock. Origin: Davis, Calif., by Steve Southwick. Prunus mahaleb open pollinated; tested as UC Mahaleb 155-1; introd. in 2001. USPP 14,321 and assigned to the Regents of the Univ. of California. Plant: vigorous rootstock for sweet cherries; Rootstock performance: grafted mature tree size is similar to Mahaleb seedling; induces slightly earlier fruiting of sweet cherry scions compared to Mahaleb seedling; good productivity; exhibited 100\% survival in field trial site heavily infested with Phytophthora spp. and stem pitting virus compared to $50 \%$ survival by standard Mahaleb seedlings; few suckers; propagation by softwood or hardwood cuttings.

UCMH 56. Productive, Phytophthora-tolerant rootstock. Origin: Davis, Calif., by Steve Southwick. Prunus mahaleb open pollinated; tested as UC Mahaleb 156-5; introd. in 2001. USPP 14,271 and assigned to the Regents of the Univ. of California. Plant: vigorous rootstock for sweet cherries. grafted mature tree size is slightly smaller than on Mahaleb 
seedling; induces slightly earlier fruiting of sweet cherry scions compared to Mahaleb seedling; good productivity; exhibited $90 \%$ survival in field trial site heavily infested with Phytophthora spp. and stem pitting virus compared to $50 \%$ survival by standard Mahaleb seedlings; few suckers; propagation is by softwood or hardwood cuttings.

UCMH 59. Semi-vigorous, productive, Phytophthora-tolerant rootstock. Origin: Davis, Calif., by Steve Southwick. Prunus mahaleb open pollinated; tested as UC Mahaleb 159-5; introd. in 2001. USPP 14,359 and assigned to the Regents of the Univ. of California. Plant: Semivigorous rootstock for sweet cherries. Rootstock performance: grafted mature tree size is $75-80 \%$ compared to Mahaleb seedling; induces slightly earlier fruiting of sweet cherry scions compared to Mahaleb seedling; good productivity; exhibited $90 \%$ survival in field trial site heavily infested with Phytophthora spp. and stem pitting virus compared to $50 \%$ survival by standard Mahaleb seedlings; few suckers, propagation by softwood or hardwood cuttings.

VSL-2. See Krymsk® 5.

\section{CHERRY-SWEET}

\section{Gregory A. Lang}

Horticulture Department, Michigan State Univ. East Lansing

13S2009. See Staccato ${ }^{\mathrm{TM}}$.

13N0770. See Stardust ${ }^{\mathrm{TM}}$.

Black York ${ }^{\mathrm{TM}}$. (cv. Haas). Midseason, dark red-skinned pollinizer for Ulster and Emperor Francis, dark red fleshed cherry. Origin: Geneva, N.Y. by Richard Wellington, Robert Andersen, Susan Brown, and Roger Way, New York State Agricultural Experiment Station, Cornell Univ.. Giant X Emperor Francis; cross made in 1940; selected in 1951; tested as NY 1725; introd. in 2004. USPP pending. Fruit: medium; cordate; medium stems; purple red skin; purple red flesh; dark red juice; firm; semi-freestone; very good flavor; ripens midseason; somewhat resistant to rain-induced splitting. Tree: self-infertile $\left(\mathrm{S}_{1} \mathrm{~S}_{4}\right)$; midseason bloom; moderately vigorous; spreading to moderately upright; cold hardy; very productive; relatively disease tolerant to brown $\operatorname{rot}$ (Monolinia fructicola) and bacterial canker (Pseudomonas sp.).

BlushingGold ${ }^{\mathrm{TM}}$ (cv. Pendleton). Mid-to-late season, blushed, pollinizer for Ulster and Emperor Francis, yellow cherry. Origin: Geneva, N.Y. by Robert Andersen, Susan Brown, and Roger Way, New York State Agricultural Experiment Station, Cornell Univ.. Yellow Glass X Emperor Francis; cross made in 1962; selected in 1969; tested as NY 8182; introd. in 2004. USPP pending. Fruit: medium; round-oblate; medium stems; yellow skin, developing a reddish blush with exposure to sun; yellow flesh; clear juice; moderately firm; semi-freestone; very good flavor; ripens mid-to-late season; somewhat resistant to rain-induced splitting. Tree: self-infertile $\left(\mathrm{S}_{1} \mathrm{~S}_{6}\right)$; early midseason bloom; moderately vigorous; spreading to moderately upright; cold hardy; very productive; relatively disease tolerant to brown rot and bacterial canker.

Brown. See Sunset Bing ${ }^{\mathrm{TM}}$.

Dame Nancy. Midseason, blushed, white-fleshed, self-fertile cherry. Origin: Lenswood, South Australia, by Andrew Granger. Stella openpollinated; cross made in 1986; selected in 1996; tested as FB420; introd. in 2002. Protected in Australia. Fruit: very large; reniform; long stems; yellow skin, developing a reddish orange blush with exposure to sun; white flesh; clear juice; firm; fair to good flavor; ripens early midseason ( 7 d before Bing); somewhat resistant to rain-induced splitting. Tree: selffertile; midseason bloom; vigorous; upright; moderately productive.
Dame Roma. Late season, mahogany red, self-fertile cherry. Origin: Lenswood, South Australia, by Andrew Granger. Black Douglas X Stella; cross made in 1986; selected in 1992; tested as FB1111; introd. in 2001. Protected in Australia. Fruit: very large; cordate; long stems; mahogany red skin; dark red flesh; firm; fair flavor; ripens late season (7 $\mathrm{d}$ after Rainier); susceptible to rain-induced splitting. Tree: self-fertile; midseason bloom; vigorous; semi-upright; very productive.

Doty. See Early Robin ${ }^{\mathrm{TM}}$.

Early Robin ${ }^{\mathrm{TM}}$ (cv. Doty). Early season, blushed, yellow cherry. Origin: Mattawa, Wash., by Robin Doty. Whole-tree mutation of Rainier; selected in 1990; introd. in 2001. USPP 13,591. Fruit: medium to large; cordate; short to medium stems; yellow skin, developing a pink blush with exposure to sun; white flesh; clear juice; firm; semi-freestone; sweet mild flavor; ripens early season ( 7 to $10 \mathrm{~d}$ before Rainier); susceptible to rain-induced splitting. Tree: self-infertile $\left(\mathrm{S}_{1} \mathrm{~S}_{3}\right)$; midseason bloom; moderately vigorous; upright to spreading; moderately productive.

Glenare. Early to early midseason, dark red skinned, red-fleshed cherry. Origin: Le Grand, Calif., by L. Glen Bradford. Tulare open pollinated; seed collected in 1990; selected in 1995; introd. in 2003. USPP 15,180 . Fruit: medium to large; oblate; medium stems; dark red skin; red flesh; red juice; firm; clingstone; sweet flavor; ripens early to early midseason ( $2 \mathrm{~d}$ after Brooks); less than average susceptibility to rain-induced splitting. Tree: self-infertile (S alleles unknown; Tulare and Sequoia recommended as pollinizers); early bloom (same as Tulare, $2 \mathrm{~d}$ before Brooks); vigorous; upright; productive.

Glenoia. See Sequoia ${ }^{\mathrm{TM}}$.

Glenred. Very early season, dark red skinned, dark red-fleshed cherry. Origin: Le Grand, Calif., by L. Glen Bradford. Tulare x Brooks; cross made in 1992; introd. in 2000. USPP 12,859. Fruit: large; oblate; long stems; dark red skin; dark red flesh; dark red juice; firm and crisp; semi-freestone; sweet, mild flavor; ripens very early season ( $4 \mathrm{~d}$ before Brooks); somewhat resistant to rain-induced splitting; resistant to fruit doubling. Tree: self-infertile (S alleles unknown; Glenare, Glenrock, Sequoia, and Brooks recommended as pollinizers); very early bloom (5 and $7 \mathrm{~d}$ before Tulare and Brooks, respectively); vigorous; upright but with horizontal fruiting limbs; very productive.

Glenrock. Early midseason, dark red skinned, red-fleshed cherry. Origin: Le Grand, Calif., by L. Glen Bradford. Tulare open pollinated; seed collected in 1990; selected in 1995; introd. in 2003. USPP 15,512. Fruit: large; oblate; medium stems; dark red skin; red flesh; pink juice; firm; semi-freestone; sweet flavor; ripens early midseason $(5 \mathrm{~d}$ after Brooks); very resistant to rain-induced splitting. Tree: self-infertile (S alleles unknown; Tulare and Sequoia recommended as pollinizer); early bloom ( 2 and $4 \mathrm{~d}$ before Tulare and Brooks, respectively); vigorous; upright; productive.

Minnie Royal. Very early season, red-skinned cherry. Origin: Modesto, Calif., by Floyd Zaiger, Leith M. Gardner, Gary N. Zaiger, and Grant G. Zaiger. Seedling 6HB480 open pollinated; introd. in 2000. USPP 12,942. Fruit: medium; oblate; long stems; red to dark red skin; rose pink to red flesh; firm and crisp; clingstone; good flavor; ripens very early season ( 2 and $20 \mathrm{~d}$ after Burlat and Bing, respectively); some resistance to rain-splitting. Tree: self-infertile (S alleles unknown); very early bloom (10 d before Burlat); moderately vigorous; upright; very productive; moderately low-chilling requirement.

PC8011-3. Early season, blushed, yellow cherry. Origin: Prosser, Wash., by Thomas Toyama, Ed Proebsting, Gregory Lang, and Matthew Whiting. PC7147-4 x PC66138-2; cross made in 1980; selected in 1990; tested as PC8011-3; introd. in 2003. USPP 15,868; assigned to Washington State Univ. Research Foundation. Fruit: large to very large; cordate; medium stems; yellow skin, developing a reddish-orange blush with exposure 
to sun; yellow flesh; clear juice; very firm; semi-freestone; very sweet flavor; ripens early season ( 7 to $9 \mathrm{~d}$ before Rainier); susceptible to raininduced splitting. and bacterial canker. Tree: self-infertile $\left(\mathrm{S}_{1} \mathrm{~S}_{3}\right)$; late season bloom; moderately vigorous; upright to spreading; moderately productive; susceptible to bacterial canker.

\section{Pendleton. See BlushingGold ${ }^{\mathrm{TM}}$.}

Royal Kay. Very early season, red-skinned cherry. Origin: Modesto, Calif., by Gary N. Zaiger, Leith M. Gardner, and Grant G. Zaiger. Seedling 13HA431 open pollinated; introd. in 2002. USPP 15,339. Fruit: large; globose; medium stems; red skin and flesh; moderately firm; clingstone; very good flavor; ripens very early season (3 and $25 \mathrm{~d}$ before Burlat and Bing, respectively); some resistance to rain-splitting. Tree: self-infertile ( $\mathrm{S}$ alleles unknown); early bloom ( $7 \mathrm{~d}$ before Burlat); vigorous; upright; very productive.

Royal Dawn. Early season, red-skinned cherry. Origin: Modesto, Calif., by Floyd Zaiger, Leith M. Gardner, Gary N. Zaiger, and Grant G. Zaiger. Seedling 32G500 open pollinated; selected in 1984; introd. in 2001. USPP 13,131. Fruit: medium to large; globose; short to medium stems; red to dark red skin; red to maroon flesh; firm; semi-clingstone; excellent flavor; ripens early season (10 to $11 \mathrm{~d}$ before Bing); some resistance to rain-splitting. Tree: self-infertile (S alleles unknown); early bloom (5 to $6 \mathrm{~d}$ before Burlat); vigorous; upright habit; very productive.

Sequoia $^{\mathrm{TM}}$ (cv. Glenoia). Early midseason, dark red-skinned, red fleshed cherry. Origin: Le Grand, Calif., by L. Glen Bradford. Unnamed seedling open pollinated; seed collected in 1993; selected in 1997; introd. in 2003. USPP 15,157. Fruit: large; oblate; dark red skin; red flesh; dark red juice; firm; clingstone; sweet flavor; ripens early midseason ( $6 \mathrm{~d}$ after Brooks); some resistance to rain-splitting (not as resistant as Tulare). Tree: self-infertile (S alleles unknown; Tulare and Glenred recommended as pollinizer); very early bloom ( 3 and $5 \mathrm{~d}$ before Tulare and Brooks, respectively); medium vigor; upright; productive.

Sir Don. Late season, dark red-black, self-fertile cherry. Origin: Lenswood, South Australia, by Andrew Granger. Black Douglas X Stella; cross made in 1986; selected in 1992; tested as FB1138; introd. in 1998. Protected in Australia. Fruit: very large; reniform; long stems; dark redblack skin; dark red-black flesh-firm; good flavor; ripens late season (with Lapins); somewhat resistant to rain-induced splitting. Tree: self-fertile; midseason bloom; vigorous; semi-upright; very productive.

Sir Douglas. Early season, mahogany-red, self-fertile cherry. Origin: Lenswood, South Australia, by Andrew Granger. Stella x Vega; cross made in 1986; selected in 1992; tested as FB122; introd. in 2002. Protected in Australia. Fruit: medium to large; cordate; long stems; mahogany-red skin; mahogany-red flesh; firm; fair to good flavor; ripens early season (14 d before Bing); somewhat resistant to rain-induced splitting. Tree: self-fertile; midseason bloom; moderate to vigorous; upright; moderately productive.

Sir Hans. Early midseason, mahogany-red, self-fertile cherry. Origin: Lenswood, South Australia, by Andrew Granger. Stella x Vega; cross made in 1986; selected in 1996; tested as FB45; introd. in 2002. Protected in Australia. Fruit: large; reniform; long stems; mahogany-red skin; mahogany-red flesh; firm; good flavor; ripens early midseason $(7 \mathrm{~d}$ before Bing). Tree: self-fertile; midseason bloom; moderately vigorous; upright; moderately productive.

Sir Tom. Late season, dark red-black, self-fertile cherry. Origin: Lenswood, So. Australia, by Andrew Granger. Black Douglas x Stella; cross made in 1986; selected in 1992; tested as FB1143; introd. in 1998. Protected in Australia. Fruit: very large; cordate; long stems; dark redblack skin; dark red-black flesh; firm; good flavor; ripens late season (with Lapins); somewhat resistant to rain-induced splitting. Tree: self-fertile; midseason bloom; very vigorous; semi-upright; moderately productive.
Staccato $^{\mathrm{TM}}$ (cv. 13S2009). Very late-season, red to dark red-skinned, self-fertile cherry. Origin: Summerland, British Columbia, by David Lane and Frank Kappel. Sweetheart open pollinated; seed collected 1982; selected in 1991; tested as 13S-20-09; introd. in 2000. USPP pending; protected in Canada. Fruit: large to very large; flattened cordate; long stems; shiny red to dark red skin; dark red flesh; red juice; very firm; clingstone; sweet flavor; ripens very late season (27 d after Bing); resistant to rain-induced splitting. Tree: self-fertile $\left(\mathrm{S}_{3} \mathrm{~S}_{4}\right)$; midseason bloom (same as Bing); moderately vigorous; upright to spreading; precocious; very productive.

Stardust $^{\mathrm{TM}}$ (cv. 13N0770). Mid-late season, blushed yellow, self-fertile cherry. Origin: Summerland, British Columbia, by David Lane and Frank Kappel. 2N-63-20 x Stella, 1976; selected in 1984; tested as 13N-07-70; introd. in 2001. Protected in Canada. Fruit: large to very large; flattened-cordate shape; short stems; yellow skin, developing a reddish-orange blush with exposure to sun; white flesh; clear juice; firm; semi-clingstone; moderately sweet flavor; ripens late season ( $7 \mathrm{~d}$ after Rainier); somewhat susceptible to rain-induced splitting. Tree: self-fertile; late-season bloom; vigorous; upright to spreading; very productive.

Sunset Bing ${ }^{\mathrm{TM}}$ (cv. Brown).Very late season, dark red-skinned, redfleshed cherry. Origin: Wenatchee Heights, Wash., by Robert Brown. Whole-branch mutation of Bing; selected in 1994; introd. in 2003. USPP 15,386 . Fruit: large to very large; cordate; thin to medium stems; purple red skin; purple red flesh; dark red juice; very firm; clingstone; very good flavor; ripens very late season (22 to $24 \mathrm{~d}$ after Bing). Tree: self-infertile ( $\mathrm{S}$ alleles unknown, presumed to be $\mathrm{S}_{3} \mathrm{~S}_{4}$ like Bing); midseason bloom (same as Bing); vigorous; upright to spreading habit; productive.

\section{GOOSEBERRY}

\author{
Kim Hummer \\ USDA-ARS National Clonal Germplasm Repository \\ Corvallis, Ore.
}

Jeanne. Late-ripening, dark red, dessert gooseberry (Ribes uva-crispa hybrid). Origin: USDA-ARS National Clonal Germplasm Repository (NCGR), Corvallis, Ore., by Kim E. Hummer. Unknown European/ American gooseberry pedigree; donated to the NCGR in 1981, from the USDA-Oregon State Univ. research collection; selected as O. T. 126, CRIB 11, and PI 555830; introd. in 2005; named in memory of the late Ms. Cheryl Jeanne Gunning, who worked in the NCGR tissue culture laboratory from 1981 to 1985 . Fruit: deep red skin; large to medium size, $5 \mathrm{~g}$, smaller than Malling Invicta but larger than Captivator; ripens in mid- to late-July, 1 week later than Malling Invicta or Captivator; ripe for $\sim 1$ week; good quality; fruit taste is full and sweet, improved over Captivator; $\mathrm{pH}=3.3$; titratable acidity $=1.85 \mathrm{~g}$ citric acid $/ 100 \mathrm{~g}$ berries $16.6 \% \mathrm{SS}$, total anthocyanins $=19.7 \mathrm{mg} / 100 \mathrm{~g}$ berries (expressed as cyanidin-3-glucoside), total phenolics $=128.4 \mathrm{mg} / 100 \mathrm{~g}$ berries (expressed as gallic acid equivalents). Plant: somewhat spreading; growing to $1.5 \mathrm{~m}$ high $\sim 1.5 \mathrm{~m}$ wide; stems have sporadic, single, nodal thorns; vegetative buds break during the last week of March in Corvallis; full bloom in midto late-April, $\sim 1$ to 2 weeks after Malling Invicta or Captivator; resistant to powdery mildew (Sphaerotheca mors-uvae) and white pine blister rust (Cronartium ribicola); not preferred by sawflies (Pachynematus spp.); somewhat susceptible to leaf spot (Drepanopeziza ribis); recommended for organic production in home or commercial plantings.

Rafzicta. See Tixia ${ }^{\mathrm{TM}}$.

Rafzuera. See Xenia ${ }^{\mathrm{TM}}$

Tixia $^{\text {TM }}$ (cv. Rafzicta). Midseason red dessert gooseberry (R. uva-crispa) with few thorns. Origin: Promo-Fruit Ltd., Rafz, Switzerland, by Peter Hauenstein. Invicta x LS 9-31-54; introd. in 1990; sibling of Rafzuera. Tixia is a Scottish word for an unarmed military commander. Canadian 
PBR and USPP pending. Fruit: bright red skin; medium size; elongated globose shape; smooth surface; good quality with persistent perianth. Plant: growth is medium to strong; mostly upright but with spreading branch angles; ripens midseason with Whinham's Industry; one-year shoots have a few soft thorns borne singly at the nodes where they occur; distal regions of the plant tend to be unarmed; suited for home, U-pick, or commercial plantings.

Xenia' $^{\text {TM }}$ (cv. Rafzuera). Early-midseason red dessert gooseberry $(R$. uva-crispa). Origin: Promo-Fruit Ltd., Rafz, Switzerland, by Peter Hauenstein. Invicta x LS 9-31-54; introd. in 1990; sibling of Rafzvicta. Xenia refers to the direct effect produced by the transfer of pollen from one strain to another to produce a hybrid. New Latin, from Greek xenia, hospitality; from xenos. Canadian PBR and USPP pending. Fruit: bright red skin; large, $11 \mathrm{~g}, 40 \%$ larger than Invicta; ovoid shape; smooth skin; good quality fruit with persistent perianth. Plant: growth is medium to strong; mostly upright but with spreading branch angles; ripens earlymidseason, between Mayduke and Whinham's Industry; distal region of the plant tends to have few, relatively weak thorns; suited for home, U-pick, and commercial plantings.

\section{GRAPE}

\section{Christopher L. Owens}

USDA-ARS Grape Genetics Research Unit, Geneva, N.Y.

12-76-71. A red seedless table grape with muscat flavor. Origin: Davis, Calif., by Harold Olmo. Redglobe X 7-7-2; cross made in 1991; selected in 1993; USPP 15,035; 27 July 2004; assigned to Marko Zaninovich, Inc, Delano, Calif. Fruit: red; spherical; $2.3 \mathrm{~g}$ (natural) to $5.4 \mathrm{~g}$ (gibberellic acid treated); muscat flavor, ripens $\sim 2$ weeks before Redglobe; skin medium thickness; rudimentary seeds; very firm; cluster small, 170 $\mathrm{g}$ (natural) to $375 \mathrm{~g}$ (gibberellic acid treated) and mostly conical but irregular in shape. Vine: moderately productive when spur pruned, up to $17,000 \mathrm{~kg} / \mathrm{ha}$.

13-19-30. A midseason, red, seedless table grape with strong muscat flavor. Origin: Delano, Calif., by Timothy Bourne, Sunview Vineyards of California, Inc. Parents are unidentified but the female is described as having Hunisa, Flame Seedless, Emperor, Thompson Seedless, and Nocera and the male having Emperor, Thompson Seedless, Calmeria, and Red Muscatel in their backgrounds; cross made in 1992; selected in 1996; USPP 14,774; 11 May 2004; assigned to Sunview Vineyards of California.Fruit: red; seedless; medium $5.2 \mathrm{~g}$ (natural) to $8.9 \mathrm{~g}$ (gibberellic acid treated); spherical; ripens $\sim 1$ week after Thompson Seedless; muscat flavor; skin medium thick and adheres to flesh; berries contain one to two rudimentary seeds that are not noticeable; firm; cluster medium (476 g natural) to large ( $857 \mathrm{~g}$ gibberellic acid treated) and loose. Vine: productive when spur pruned, up to $39,630 \mathrm{~kg} / \mathrm{ha}$; medium vigor.

13-21-12. A large-fruited, late-ripening, white seedless table grape. Origin: Delano, Calif., by Timothy Bourne, Sunview Vineyards of California, Inc. Calmeria $x$ an unidentified male parent but described as having Emperor, Thompson Seedless, and Calmeria in its background; cross made in 1992; selected in 1996; USPP 14,773; 11 May 2004; assigned to Sunview Vineyards of California. Fruit: white, medium $4.2 \mathrm{~g}$ (natural) to $9.4 \mathrm{~g}$ (gibberellic acid treated); elliptic to oblong; neutral flavor; skin thick, adheres to flesh; berries contain one to two small seed traces; very firm; cluster large, $1291 \mathrm{~g}$ (natural), loose, and elliptic. Vine: very productive when spur pruned, up to $58,637 \mathrm{~kg} / \mathrm{ha}$; medium vigor.

13-29-281. A late-ripening, red, large-fruited seedless table grape. Origin: Delano, Calif., by Timothy Bourne, Sunview Vineyards of California, Inc. Parents are unidentified but the female is described as having Hunisa, Emperor, Thompson Seedless, and Nocera and the male having Emperor, Nocera, and Red Muscatel in their backgrounds; cross made in 1992; selected in 1995; USPP 15,033; 27 July 2004; assigned to Sunview Vineyards of California. Fruit: red; medium, $5.2 \mathrm{~g}$ (natural) to $8.7 \mathrm{~g}$ (gibberellic acid treated); narrow elliptic; neutral flavor; skin adheres to flesh; rudimentary seeds; very firm; cluster large, (574 g natural to $1340 \mathrm{~g}$ gibberellic acid treated), loose, and elliptical. Vine: medium vigor; very productive when spur pruned, up to $57,639 \mathrm{~kg} / \mathrm{ha}$.

14-44-248. A reddish-black, midseason seeded table grape with large berries. Origin: Delano, Calif., by Timothy Bourne, Sunview Vineyards of California, Inc. Female parent unidentified, described as having Hunisa, Flame Seedless, Emperor, and Thompson Seedless in background $\mathrm{x}$ Fantasy Seedless; cross made in 1993; selected 1996; USPP 14,923; 22 July 2004; assigned to Sunview Vineyards of California, Inc. Fruit: reddish-black; large, $12.8 \mathrm{~g}$ (natural); elliptic; very firm; seeds present, averaging $48 \mathrm{mg} / \mathrm{seed}$, neutral flavor; cluster large (1069 g natural) and conical with low bunch density. Vine: high vigor; very productive when spur pruned, up to $49,470 \mathrm{~kg} / \mathrm{ha}$.

14-48-258. A large fruited, late midseason, seeded red-black table grape. Origin: Delano, Calif., by Timothy Bourne, Sunview Vineyards of California, Inc. Female parent was un-named black table grape of uncertain parentage with large berry size x Fantasy Seedless; cross made in 1993; selected in 1997; USPP 15,774; 24 May 2005; assigned to Sunview Vineyards of California. Fruit: red-black; large (12.8 g); obovate to elliptic; neutral flavor; two to four seeds present per berry averaging $43 \mathrm{mg}$ each; very firm; cluster medium (1392 g untreated), conical, and dense. Vine: medium vigor, very productive when spur pruned, up to $64,157 \mathrm{~kg} / \mathrm{ha}$.

15-97-77. A late-ripening, black, seedless table grape. Origin. Delano, Calif., by Timothy Bourne, Sunview Vineyards of California, Inc. Parents are unidentified but the female is described as having Hunisa, Emperor, and Thompson Seedless, and the male having Emperor, Thompson Seedless, and Almeria in their backgrounds; cross made in 1994; selected in 1997; USPP 14,865; 8 June 2004; assigned to Sunview Vineyards of California. Fruit. black; seedless; large, $5.6 \mathrm{~g}$ (natural) to $10.9 \mathrm{~g}$ (gibberellic acid treated); obovate; ripens $\sim 1$ month after Thompson Seedless; neutral flavor; skin medium thick, adheres to flesh and develops bitter flavor if exposed to sunlight; berries contain one to two rudimentary seeds; very firm; cluster is large $(\sim 1000 \mathrm{~g}$ natural to over $1500 \mathrm{~g}$ if gibberellic acid treated) and loose but well-filled. Vine: very productive when spur pruned, up to $70,000 \mathrm{~kg} / \mathrm{ha}$; high vigor.

Autumn King. A late-ripening, white, large-fruited seedless table grape with a neutral flavor. Origin: Fresno, Calif., by David Ramming and Ronald Tarailo, USDA-ARS Horticultural Crops Research Laboratory. A61-20 x B99-131; cross made in 1993; selected in 1996; tested as C10; introd. in 2005; USPP 16,284; 21 Feb. 2006; assigned to the United States of America as represented by the Secretary of Agriculture. Fruit: white; ripens eight weeks after Thompson Seedless; berry cylindrical to ovoid and averages $9.8 \mathrm{~g}$; berries from girdled vines treated with 2.5 to $5 \mathrm{ppm}$ gibberellic acid at bloom average $11.5 \mathrm{~g}, 25 \mathrm{~mm}$ in diameter and $35 \mathrm{~mm}$ in length; flavor sweet and neutral; skin medium thickness and adheres to flesh; berries contain two to three aborted seeds that are small and not noticeable when eaten; cluster is medium size and length (500 $\mathrm{g}$ ), conical to cylindrical, and well-filled; berry attachment to pedicel is very good and little post-harvest shatter occurs. Vine: medium in vigor; production averages $17 \mathrm{~kg} /$ vine when head trained and pruned to 5-6 canes and grown on a " $Y$ " trellis; is sensitive to gibberellic acid applied at berry set that has reduced fruitfulness the following year; gibberellic acid application at fruit set not recommended.

GR7. A cold hardy, early midseason red wine grape. Origin: Geneva, N.Y., by B. Reisch, R. Luce, T. Henick-Kling, and R. Pool, New York State Agricultural Experiment Station, Cornell Univ.. Buffalo x Baco Noir; cross made in 1947; selected in 1953; released in 2003; not patented but propagation requires licensing by Cornell Research Foundation. Fruit: black; ripens mid-Sept. to early Oct. in Geneva; in warm years wines have 
cherry or red berry aromas with some V. labrusca character and in cool years wines tend to have some vegetative or herbaceous aromas; color intensity as good as Baco Noir; tannin structure typically better than Baco Noir; wines often have high acidity and high $\mathrm{pH}$; sugar accumulation typically ranges from 19.2 to $22 \% \mathrm{SS}$; cluster average 118 to $141 \mathrm{~g}$. Vine: appears resistant to ringspot virus complex; fruit yield averaged 15,000 $\mathrm{kg} \cdot \mathrm{ha}^{-1}$; well-adapted to mechanized production; hardiness similar to DeChaunac and Marechal Foch; early budbreak; moderately susceptible to powdery mildew (Uncinula necator), downy mildew (Plasmopara viticola), and botrytis bunch rot (Botrytis cinerea).

Marquette. A highly cold hardy, disease resistant red wine grape. Origin: St. Paul, Minn., by Peter Hemstad and James Luby, Univ. of Minnesota. MN1094 x Ravat 262; cross made in 1989; selected in 1994; tested as MN 1211; released 2005; USPP pending. Fruit: black; ripens midseason, a few days before Frontenac; sugar accumulation typically high, averaging $26.7 \%$ SS; acid levels averaging $1.6 \%$, lower than Frontenac; wines possess deep red color with aromas of cherry, black pepper, spice, and berry; substantial tannin structure; cluster small to medium, two per shoot, and cluster thinning not required. Vine: highly cold hardy, has withstood $-36^{\circ} \mathrm{C}$ without serious injury; resistance is good to downy mildew, powdery mildew, and black rot and requires minimal spray program; moderate resistance to foliar phylloxera (Daktulosphaira vitifoliae); open and orderly growth habit; yields average $5.6 \mathrm{~kg} / \mathrm{vine}$ or $8069 \mathrm{~kg} / \mathrm{ha}$.

Scarlet Royal. A midseason, red seedless table grape with large, sweet, firm berries with neutral flavor. Origin: Fresno, Calif., by David Ramming and Ronald Tarailo, USDA-ARS Horticultural Crops Research Laboratory. C33-30 x C51-63; cross made in 1992; selected in 1995; tested as B1; introd. in 2005; USPP 16,229; 31 Jan. 2006; assigned to the United States of America as represented by the Secretary of Agriculture. Fruit: red; ripens between Flame Seedless and Crimson Seedless; berry oval; average $5.8 \mathrm{~g}$, berries from girdled vines treated with 2.5 ppm gibberellic acid at bloom and $20 \mathrm{ppm}$ gibberellic acid at berry set average $8.3 \mathrm{~g}, 22 \mathrm{~mm}$ in length, and $33 \mathrm{~mm}$ in length; flavor is sweet and neutral; skin is medium to think and adheres to the flesh; berry flesh is firm and meaty; berry contains three to four aborted seeds that are small and not noticeable when eaten; fruit retains firmness during 2 months of cold storage; cluster is large $(800 \mathrm{~g})$, conical, and medium to well filled with berry attachment to pedicel very good and little postharvest shatter occurs. Vine: medium in vigor; production averages $27 \mathrm{~kg} / \mathrm{vine}$ when trained to quadrilateral cordons, pruned to two-bud spurs and grown on a "Y" trellis.

Sugratwentysix. A late-midseason green seedless table grape with ability to hang on the vine. Origin: Bakersfield, Calif., by David Cain and Michael Striem, Sun World International Inc; Sun World Seedling 86005-098-073 x Sun World Seedling 85022-079-636; cross made in 1990; selected in 1994; USPP 15,110; 24 Aug. 2004; assigned to Sun World International, Inc. Fruit: green; medium, $4.0 \mathrm{~g}$; elliptic to ovate; ripens $\sim 1$ month after Thompson Seedless; thick skin; rudimentary seeds averaging $4.7 \mathrm{mg}$; firm. Cluster: medium, $635.8 \mathrm{~g}$; conical and loose. Vine: high vigor; medium productivity.

Sugratwentyseven. A black, seedless, medium fruited table grape. Origin: Bakersfield, Calif., by David Cain and Michael Striem, Sun World International Inc., Calinda X Fantasy; cross made in 1990; selected in 1994; USPP 15,468; 4 Jan. 2005; assigned to Sun World International, Inc. Fruit: black; midseason ripening $\sim 7 \mathrm{~d}$ after Thompson Seedless; berry $5.1 \mathrm{~g}$; seedless; firm; crisp; long-elliptic; aromatic; rudimentary seeds $\sim 3.7 \mathrm{mg}$; cluster averages $687 \mathrm{~g}, 24.1 \mathrm{~cm}$ in length and $14.7 \mathrm{~cm}$ in width. Vine: vigorous, productive.

Sugratwentyeight. A midseason, black seedless table grape with round berries. Origin: Bakersfield, Calif., by David Cain and Michael Striem, Sun World International Inc. Sun World Seedling 89145-062-244 x Sun World Seedling 89014-019-280; cross made in 1992; selected in 1995;
USPP 15,229; 12 Oct. 2004; assigned to Sun World International, Inc. Fruit: black; large, $6.1 \mathrm{~g}$; round; ripens 1 week before Redglobe; thick tannic skin, adheres to flesh; rudimentary seeds averaging $1.1 \mathrm{mg}$; firm; cluster large (653 g), conical, and loose. Vine: medium vigor, high productivity.

Sweet Scarlet. A midseason, red seedless table grape with light muscat flavor. Origin: Fresno, Calif., by David Ramming and Ronald Tarailo, USDA-ARS Horticultural Crops Research Laboratory, Fresno, Calif. C33-30 x C103-41; cross made in 1989; selected in 1992; tested as A6116; introd. in 2005; USPP 15,891; 26 July 2005; assigned to the United States of America as represented by the Secretary of Agriculture. Fruit: red; ripens with Ruby Seedless; berry oval to elliptical and averages 3.6 $\mathrm{g}$; berries from girdled vines treated with $20 \mathrm{ppm}$ gibberellic acid at berry set average $5.1 \mathrm{~g}, 19 \mathrm{~mm}$ in diameter, and $24 \mathrm{~mm}$ in length; flavor is sweet with a light muscat flavor; berries contain one to two aborted seeds that are small and unnoticeable; fruit retains firmness during two months of storage; muscat flavor is retained during eight weeks of storage; cluster is large $(1.7 \mathrm{~kg})$, conical with large shoulders, medium to well-filled, and need to be tipped to less than six laterals to make them smaller; pedicel is thinner and has tendency to dry out more rapidly compared to Crimson Seedless. Vine: medium in vigor; production averages 27 $\mathrm{kg} / \mathrm{vine}$ when quadrilateral trained and spur pruned to two buds and grown on a "Y" trellis.

Triplett Blanc. A high-yielding, white wine grape. Origin: Ceres, Calif., by Fay Triplett. Colombard x Vernaccia Sarda; tested as 99-9A; introd. 2004; not patented. Fruit: white; medium, averaging 2.3 g; round; neutral flavor; maintains high acidity in warm climates; averaged 20.3 $\% \mathrm{SS}, 0.87 \mathrm{~g} / 100 \mathrm{~mL}$ titratable acidity and $\mathrm{pH} 3.2$; cluster is large $(450 \mathrm{~g})$, long-conical, shouldered, and well-filled. Vine: extremely vigorous and productive; strong upright shoots; canopy is not dense and is not prone to strong lateral shoot development.

\section{GRAPE ROOTSTOCK}

\section{Christopher L. Owens}

USDA-ARS Grape Genetics Research Unit, Geneva, N.Y.

RS-3. A nematode resistant rootstock. Origin: Fresno, Calif., by Michael McKenry, Univ. of California. Ramsey x Schwarzmann; cross made 1991; USPP pending. Vine: moderately vigorous; in sandy, irrigated soils imparts $2 / 3$ the vigor and yield of Freedom; demonstrates resistance to all known aggressive populations of root knot nematode; shows good resistance to Xiphinema index and Pratylenchus vulnus and slight susceptibility to citrus nematode (Tylenchulus semipenetrans).

RS-9. A nematode resistant rootstock. Origin: Fresno, Calif., by Michael McKenry, Univ. of California. Ramsey x Schwarzmann; cross made 1991; USPP 16,115; 15 Nov. 2005; assigned to the Univ. of California. Vine: low vigor, equivalent to Schwarzmann, demonstrates resistance to a gall-initiating Meloidogyne arenaria pathotype from Harmony and a nongalling $M$. chitwoodi that also attacks Harmony; shows good resistance to $X$. index, and $P$. vulnus and slight susceptibility to citrus nematode.

\section{NECTARINE}

\section{Jerome L. Frecon}

Rutgers - The State Univ. of New Jersey, New Brunswick

August Bright. Yellow-fleshed, late-season, firm, clingstone nectarine. Origin: Le Grand, Calif., by L. Glen Bradford August Red x Diamond Princess. USPP 15,143 issued 14 Sept. 2004. Fruit: globose to slightly oblong; uniform; large; dark red streaking over a strong reddish-orange 
with a light yellow ground color; flesh rich, very firm, crisp; blend of acid and sugar with very good flavor; ripens 12 Aug. in Le Grand and 2 weeks earlier than August Red. Tree: upright; vigorous; medium; dense; productive; flowers nonshowy, small, pale pink to moderate purplishpink; leaf glands mostly reniform, medium, alternate.

Autumn Blaze. Yellow-fleshed, very late-season, firm, clingstone nectarine. Origin: Modesto, Calif., by Chris F. Zaiger, Gary N. Zaiger, Leith M. Gardner, and Grant G. Zaiger. Unnamed selection x ZeeGlo. USPP 12,392 issued 5 Feb. 2002. Fruit: nearly globose; medium; red blush covering most of the surface with light yellow to orange-yellow ground color; flesh is firm, meaty, moderately juicy; sweet with very good flavor; ripens $23 \mathrm{Aug}$. and $18 \mathrm{~d}$ later than ZeeGlo in Modesto. Tree: upright; vigorous; large; medium-dense; productive; flowers large, showy, pink to pastel pink; leaf glands reniform, small to medium; chilling requirement $\sim 800 \mathrm{~h}$.

Bright Sweet. Yellow-fleshed, firm, sub-acid, sweet-pitted clingstone nectarine. Origin: Le Grand, Calif., by L. Glen Bradford. Open-pollinated seedling of unnamed nectarine. USPP 14,547 issued 17 Feb. 2004. Fruit: globose; uniform; large; very deep red over strong red-orange, with light orange-yellow ground color; flesh rich, very firm, crisp; flavor sub-acid, very sweet with excellent eating quality; ripens 20 July and 8 dearlier than Fire Sweet in Le Grand. Tree: spreading; vigorous; medium; productive; flowers large, showy, pale purplish-pink, self-fertile; leaf glands globose when young filling out to reniform, small, opposite.

Burnectone. Yellow-fleshed, early season, freestone nectarine. Origin: Fowler, Calif., by John K. Slaughter and Timothy J. Gerdts. Openpollinated seedling of May Diamond. USPP 12,518 issued 2 Apr. 2002 and assigned to The Burchell Nursery, Inc. Fruit: globose; uniform; large; $80 \%$ to $90 \%$ red blush to orange-red blush over yellow-golden ground color; flesh firm, nonmelting; very sweet, moderate acidity, pleasant, balanced with very good to excellent flavor; ripens 25 May and before May Diamond. Tree: upright to upright-spreading; average to above average size; productive; flowers showy, large, light to medium-pink; leaf glands globose, small.

Burnectwo. Yellow-fleshed, early midseason, firm, clingstone nectarine. Origin: Fowler, Calif., by John K. Slaughter and Timothy J. Gerdts. Grand Diamond x Flameglo. USPP 12,555 issued 16 Apr. and assigned to The Burchell Nursery, Inc. Fruit: globose; uniform; large; $80 \%$ to $90 \%$ of the fruit surface covered with red blush over yellow-golden ground color; flesh firm, fine; sweet with moderate acidity and very good to excellent flavor; ripens 1 July and with Summer Grand in Fowler. Tree: upright-to-upright spreading; average to above-average size; productive; flowers showy, large, light to medium-pink, self-fertile; leaf glands reniform, small.

Burnecthree. Yellow-fleshed, midseason, firm, clingstone nectarine. Origin: Fowler, Calif., by John K. Slaughter and Timothy J. Gerdts. Grand Diamond x Flameglo. USPP 12,571 issued 23 Apr. 2002 and assigned to The Burchell Nursery, Inc. Fruit: globose; medium; $80-90 \%$ crimson blush over yellow-orange ground color; flesh is firm, fine, nonmelting; very sweet, moderate acidity, pleasant and well balanced, very good to excellent flavor; ripens 8 July and 1 week later than Summer Grand in Fowler. Tree: upright to upright-spreading; average to above-average productivity; flowers showy, large, light pink to very pale-pink, selffertile; leaf glands reniform and small.

Burnectfour. Yellow-fleshed, very late-season, firm, clingstone nectarine. Origin: Fowler, Calif., by John K. Slaughter and Timothy J. Gerdts. September Red x Spring Red. USPP 13,477 issued 14 Jan. 2003 and assigned to The Burchell Nursery. Fruit: moderately oblate; mediumlarge; uniform; variable red to red-orange blush with yellow-orange ground color; flesh firm, dense, moderately juicy; sweet, mildly acidic, balanced and pleasant, good flavor; ripens 8 Sept. and $10 \mathrm{~d}$ later than September Red in Fowler. Tree: upright; moderately vigorous; medium size; medium dense; productive; flowers are showy, medium-large to large, light pink to medium to dark pink, self-fertile; leaf glands globose, medium to small; chilling requirement $\sim 600 \mathrm{~h}$.

Burnectfive. Yellow-fleshed, early season, clingstone nectarine. Origin: Fowler, Calif., by John K. Slaughter and Timothy J. Gerdts; Openpollinated seedling of Mayfire nectarine; Introduced on 31 Dec. 2002 as USPP 13,443; Assigned to The Burchell Nursery. Fruit: Moderately oblate, medium large, variable dark red with a yellow orange ground color; Flesh is firm, dense, moderately juicy, sweet, mildly acidic, pleasant and balanced, very good flavor; ripens 15-23 May, or 12 days after Mayfire in Fowler. Tree: flowers are showy, large, light pink to medium and dark pink; leaf glands are reniform, medium; Tree is upright, moderately vigorous, medium large, medium dense, productive; chilling requirement of $\sim 550 \mathrm{~h}$.

Burnectsix. White-fleshed, early-midseason, firm, clingstone nectarine. Origin: Fowler, Calif., by John K. Slaughter and Timothy J. Gerdts. Grand Diamond $\mathrm{x}$ white-fleshed nectarine selection. USPP 14,518 issued 10 Feb. 2004 and assigned to The Burchell Nursery, Inc. Fruit: moderately oblate; large; uniform; $75-95 \%$ of surface covered with reddish-orange to dark red-purple over light yellow ground color; flesh white, firm, dense, melting; fragrant, aromatic, sweet, acidic flavor; ripens 28 June and 5 d earlier than Grand Diamond in Fowler. Tree: upright; vigorous; medium-large; medium dense; productive; flowers showy, large, light pink to medium pink; leaf glands reniform and moderately small; chilling requirement $\sim 750 \mathrm{~h}$.

Burnectseven. Yellow-fleshed, midseason, large to very large, clingstone nectarine. Origin: Fowler, Calif., by John K. Slaughter and Timothy J. Gerdts. Summer Red x Diamond Ray. USPP 13,589 issued 18 Feb. 2003 and assigned to The Burchell Nursery, Inc. Fruit: moderately oblate; uniform; $70 \%$ to $90 \%$ red-orange to dark red with yellow-orange ground color; flesh firm, dense; sweet, mildly acidic, very good flavor; ripens 15 July and 15 d earlier than Summered in Le Grand, Calif. Tree: upright; moderately vigorous; medium dense; medium large; productive; flowers are showy, large, light pink to medium dark-pink; leaf glands reniform, small.

Burnectten. Yellow-fleshed, very early season, clingstone nectarine. Origin: Fowler, Calif., by John K. Slaughter and Timothy J. Gerdts. Rich Lady peach x Suncoast peach. USPP 14,442 issued 6 Jan. 2004 and assigned to The Burchell Nursery, Inc. Fruit: moderately globose; medium-large size for season; reddish-orange to dark red blush over 75\% to $95 \%$ of skin with yellow-orange ground color; flesh is firm, dense, nonmelting; sweet, mildly acidic, very good flavor; ripens 5 May and 20 d earlier than Suncoast. Tree: upright; moderately vigorous; medium large; medium dense; productive; flowers are large, showy, light pink; leaf glands are reniform, alternate; chilling requirement $\sim 350 \mathrm{~h}$.

Burnecteleven. Yellow-fleshed, clingstone, late midseason nectarine. Origin: Fowler, Calif., by John K. Slaughter and Timothy J. Gerdts. Summer Bright $x$ peach selection. USPP 14,363 issued 9 Dec.2003 and assigned to The Burchell Nursery, Inc. Fruit: moderately oblate; uniform; large; red to reddish-orange blush over $75 \%$ to $95 \%$ of surface with yellow-orange ground color; flesh firm, dense, nonmelting; sweet, mildly acidic, and very good flavor; ripens 24 July and $10 \mathrm{~d}$ later than Summer Bright in Fowler. Tree: upright; moderately vigorous; mediumlarge; medium dense; productive; flowers are nonshowy, medium, light pink; leaf glands globose, alternate; chilling requirement $\sim 750 \mathrm{~h}$.

Burnecttwelve. Yellow-fleshed, early season, sub-acid, clingstone nectarine. Origin: Fowler, Calif., by John K. Slaughter and Timothy J. Gerdts. Arctic Star x Crimson Baby. USPP 14,412 issued 2 Dec. 2003 and assigned to The Burchell Nursery, Inc. Fruit: moderately oblate; uniform; large; $75 \%$ to $90 \%$ reddish-orange to dark red blush over a light yellow ground color; flesh firm, dense, melting; sweet, low-acid to sub acid, pleasant, and very good flavor; ripens 19 May and 7 earlier 
than Arctic Star in Fowler. Tree: upright; vigorous; medium-large; medium dense; productive; flowers showy, large, light pink to mediumpink, self-fertile; leaf glands reniform and moderately small; chilling requirement $\sim 500 \mathrm{~h}$.

Burnectthirteen. White-fleshed, early season, sub-acid, clingstone nectarine. Origin: Fowler, Calif., by John K. Slaughter and Timothy J. Gerdts. Crimson Baby x Arctic Star. USPP 14,517 issued 10 Feb. 2004 and assigned to The Burchell Nursery, Inc. Fruit: round; uniform; large; $75 \%$ to $95 \%$ skin with reddish-orange to dark red blush over light yellow; flesh firm, dense; sweet, sub-acid, pleasant, very good flavor; ripens 24 May and 5 d earlier than Crimson Baby in Fowler. Tree: upright; vigorous; medium-large; medium dense; productive; flowers showy, large, light pink to medium pink, self-fertile; leaf glands reniform, moderately small, opposite; chilling requirement $\sim 500 \mathrm{~h}$.

Burnectsixteen. Yellow-fleshed, clingstone, sub-acid, early season nectarine. Origin: Fowler Calif., by John K. Slaughter and Timothy J. Gerdts.; unnamed nectarine X Crimson Baby. USPP 15,825 issued 5 July 2005 and assigned to The Burchell Nursery, Inc. Fruit: oblate; large for early season; deep red over $80 \%$ to $90 \%$ of skin surface with yellow-range ground color; flesh firm, juicy, dense; good, pleasant, sub-acid flavor; ripens 27 May and near Honeykist in Fowler. Tree: upright; medium; vigorous; medium dense; vigorous; productive; flowers showy, large, light pink; leaf glands globose, opposite; chilling requirement $\sim 600 \mathrm{~h}$.

Burnectseventeen. Yellow-fleshed, clingstone, late-season nectarine. Origin: Fowler Calif., by John K. Slaughter and Timothy J. Gerdts. Unnamed selection X unnamed peach. USPP 15,694 issued 22 Mar. 2005 and assigned to The Burchell Nursery, Inc. Fruit: oblate; large; uniform; red-orange over $80-90 \%$ of the surface, yellow orange ground color; flesh firm, juicy; sweet and mildly acidic; ripens 7 Aug. in Fowler. Tree: upright; medium-large; moderately vigorous; medium dense; productive; flowers large, showy, light pink; leaf glands reniform; chilling requirement $\sim 650 \mathrm{~h}$.

Coelho. White-fleshed, late midseason, nectarine. Origin: Riverdale, Calif., by J.W. Coelho. Chance seedling believed to be from July Red. USPP 14,354 issued 9 Dec. 2003 and assigned to Terra Linda Farms. Fruit: ovoid; medium; 70-95\% red blush with yellow streak on suture line on skin; flavor acidic and good; ripens 14 July in Laton, Calif. Tree: upright to upright-spreading; vigorous; large, productive; Flowers are medium, dark pink, self-fertile; leaf glands are variable.

Honey Diva. Yellow-fleshed, low-acid, firm, clingstone peach. Origin: Modesto, Calif., by Gary N. Zaiger, Leith M. Gardner, and Grant G. Zaiger. Seedling of two unnamed selections. USPP 15,291 issued 2 Nov. 2004. Fruit: globose; large; red with yellowish- red ground color; flesh firm, meaty, moderately juice; holds well; sweet, mild low-acid flavor; ripens 13 Aug. and four weeks later than Honey Royale. Tree: upright; vigorous; large; medium dense; productive; flowers large, showy, pink, self-fertile; leaf glands reniform, small to medium.

Honey Fire. Yellow-fleshed, moderately low-chill, sub-acid, early season, clingstone nectarine. Origin: Modesto, Calif., by Chris F. Zaiger, Gary N. Zaiger, Leith M. Gardner, and Grant G. Zaiger. Seedling of two unnamed selections. USPP 12,418 issued 26 Feb. 2002. Fruit: nearly globose; medium; red over most of surface with small randomly spaced areas of golden-yellow ground color; flesh firm, meaty; sweet, mild, sub-acid and very good flavor; ripens 5 June 5 and $8 \mathrm{~d}$ earlier that Honeykist nectarine in Modesto.. Tree: upright; vigorous; large; productive; flowers large, showy, pink to light pink, self-fertile; leaf glands reniform, medium; chilling requirement 400 to $450 \mathrm{~h}$.

Honey Haven. Yellow-fleshed, early season, large, clingstone nectarine. Origin: Modesto, Calif., by Chris F. Zaiger, Gary N. Zaiger, Leith M. Gardner, and Grant G. Zaiger. Seedling of two unnamed selections. USPP 12,393 issued 5 Feb. 2002. Fruit: globose; nearly symmetrical; medium-large; red to deep red over a yellow ground color; flesh firm, meaty, medium juicy; very good balance between acid and sugar, with good eating quality; ripens 15 June and $3 \mathrm{~d}$ earlier than May Grand in Modesto. Tree: upright; vigorous; large; medium dense; productive; flowers large, showy, light pink-to-pink, self-fertile; leaf glands reniform, medium alternate; chilling requirement $\sim 800 \mathrm{~h}$.

Late Pearl. White-fleshed, very late season, sub-acid nectarine. Origin: Le Grand, Calif., by L. Glen Bradford. Fire Pearl x September Red. USPP 13,479 issued 14 Jan. 2004. Fruit: globose; uniform; symmetrical; medium; dark red over a yellowish-white groundcolor; flesh rich, firm, crisp; sub-acid and very sweet; ripens 5 Sept. in Le Grand. Tree: tree is spreading; vigorous; dense; medium; productive; flowers showy, large, pale purplish-pink to deep purplish-pink; leaf glands globose and alternate.

PF 11. Yellow-fleshed, midseason, freestone nectarine. Origin: Coloma, Mich., by Paul J. Friday. Unknown parentage. USPP 15,661 issued 15 Mar. 2005. Fruit: oblate-globose; medium; dark red color over $100 \%$ of surface; flesh firm; excellent flavor; ripens 5 Aug. and after Redhaven in Coloma. Tree: spreading to upright; medium-large; medium-dense; vigorous; very productive; flowers large, showy, rich pink; no leaf glands.

Plablanec. White-fleshed, low-chill, very early, clingstone nectarine. Origin: Cartaya (Huelva), Spain, by J.M.A. Lopez. Seedling of two unnamed selections. USPP 14,556 issued 24 Feb. 2004 and assigned to Plantas de Navarra, S.A. Fruit: round; uniform; 95\% of surface covered with brilliant red, $5 \%$ with yellow-green ground color; flesh fine, melting; flavor very good, sweet; ripens $15 \mathrm{Apr}$. and $20 \mathrm{~d}$ before Mayglo. Tree: upright to upright spreading; large; productive; flowers large, showy, self-fertile; leaf glands reniform, opposite; chilling requirement $\sim 250-300 \mathrm{~h}$.

Platornec. Yellow-fleshed, firm, low-chill, midseason nectarine. Origin: Cartaya (Huelva), Spain, by J.M.A. Lopez. Seedling of two unnamed selections. USPP 14,768 issued 11 May 2004 and assigned to Plantas de Navarra, S.A. Fruit: round; uniform; medium; $100 \%$ of skin covered with very brilliant red-purple; flesh fine, firm, melting; sweet, mediumacidic and flavor very good to excellent; ripens 2 June and $20 \mathrm{~d}$ after Mayglo. Tree: upright to upright spreading; average to above average size; regularly productive; flowers medium, pink, self-fertile; leaf glands reniform; chilling requirement 200-300 h.

Rose Bright. Yellow-fleshed, clingstone, early season nectarine. Origin: Le Grand, Calif., by L. Glen Bradford. Red Diamond x Rose Diamond. USPP 15,845 issued 12 July 2005. Fruit: globose; uniform; large for early season; red over most of the surface with light yellow ground color; flesh rich, very firm; flavor moderately acidic and good; ripens in early season, $30 \mathrm{~d}$ before Red Diamond in Le Grand. Tree: spreading; large; vigorous; dense; productive; flowers showy, large, self-fertile; leaf glands globose alternate and opposite.

Royal Bright. Yellow-fleshed, firm, late-season, clingstone nectarine. Origin: Le Grand, Calif. by L. Glen Bradford. Summer Bright x August Snow. USPP 14,594 issued 9 Mar. 2004. Fruit: globose; uniform; large; very deep red streaked over a dark reddish-orange with minor light yellow-brown ground color; flesh rich, very firm, crisp; flavor mildly acidic, sweet and very good; ripens on 6 Aug. and $\sim 17 \mathrm{~d}$ after Summer Bright in Le Grand. Tree: upright; vigorous; large; dense; productive; flowers nonshowy, small, pale purplish-pink, self-fertile; leaf glands are globes when very young filling out to reniform, mostly alternate.

Spring Pearl. White-fleshed, clingstone, sub-acid, early midseason nectarine. Origin: Le Grand, Calif., by L. Glen Bradford. Open-pollinated seedling of unnamed nectarine selection. USPP 16,034 issued 11 Oct. 2005. Fruit: globose; uniform; large; very dark red with moderate red over slight yellow ground color; flesh rich, firm and very crisp; flavor 
mildly sub-acid, good; ripens 25 June 25 and 5 d later than June Pearl in Le Grand. Tree: spreading; medium; vigorous; dense; productive; flowers large, showy, light purplish-pink, self-fertile; leaf glands reniform, mostly alternate.

Sweet August. Yellow-fleshed, late-season, sub-acid, firm clingstone nectarine, Origin: Le Grand, Calif., by L. Glen Bradford. August Snow X August Red. USPP 13,474 issued 24 Jan. 2003. Fruit: globose; symmetrical; large; uniform; very dark red to deep red over most of the surface with brilliant yellow ground color; flesh rich, firm, crisp; flavor sub- acid, sweet, very good; ripens 8 Aug. and 10 d earlier than August Red in Le Grand. Tree: spreading; vigorous; medium; dense; productive, flowers large, showy, pale purplish-pink to deep purplish-pink; leaf glands globose, small, opposite to alternate.

Sweet Surprise. Yellow-fleshed, midseason, sub-acid, freestone nectarine. Origin: Le Grand, Calif., by L. Glen Bradford. Red Glen X unnamed white-fleshed nectarine selection. USPP 13,456 issued 7 Jan. 2003. Fruit: globose; somewhat asymmetrical; large; uniform; very deep red over strong reddish-orange with light orange-yellow ground color; flesh rich, firm, crisp; flavor sub-acid, sweet, and very good; ripens 6 July in Le Grand. Tree: spreading; vigorous; large; dense; productive; flowers showy, large, pale purplish-pink and self-fertile; leaf glands reniform, small, opposite, alternate.

Taylor 14L22. Yellow-fleshed, early season clingstone nectarine. Origin: Reedley, Calif., by J.W. Taylor. Unreleased selection x Big Jim. USPP 12,509 issued 2 Apr. 2002 and assigned to Ito Packing Co. Fruit: globose; large; deep red to dark red; flesh very firm, juicy; flavor excellent with good balance of sugar and acid; ripens 28 May 28 in Reedley. Tree: spreading; vigorous; large; productive; flowers large, showy, pink, selffertile; leaf glands reniform, medium, opposite.

Western Sweet. Yellow-fleshed, sub-acid, firm, midseason, freestone nectarine. Origin: Le Grand, Calif., by L. Glen Bradford. Red Glen X unnamed selection. USPP 15,055 issued 3 Aug. 2004. Fruit: oblong; uniform; large; dark red over strong reddish-orange with brilliant orangeyellow ground color; flesh rich, firm, crisp; flavor sub-acid, very sweet and very good; ripens 5 July and 5 d earlier than Grand Sweet in Le Grand. Tree: upright; vigorous; medium; dense; productive; flowers showy, large, pale pink; leaf glands globose when young filling out to reniform, opposite and small.

\section{PEACH}

\section{Jerome L. Frecon}

Rutgers - The State Univ. of New Jersey,

New Brunswick, N.J.

Bright Princess. Yellow-fleshed, firm, midseason, freestone peach. Origin: Le Grand, Calif., by L. Glen Bradford. Seedling of Spring Bright nectarine $x$ unnamed peach. USPP 14,695 issued 13 Apr. 2004. Fruit: primarily globose with slight axial compression; uniform; large; very deep red over moderate red orange over $100 \%$ of surface; flesh rich, firm, crisp; flavor excellent with balance of sugar and acid; ripens 22 June in Le Grand, 15 d earlier than Diamond Princess. Tree: spreading; vigorous; medium size, dense; productive; flowers are showy, large, light purplish pink, and self-fertile; leaf glands reniform, both opposite and alternate.

Burpeachone. Yellow-fleshed, very early season, firm, semi-freestone peach. Origin: Fowler, Calif., by John K. Slaughter, and Timothy J. Gerdts. Unnamed peach selection x Rich Lady. USPP 12,156 issued 23 Oct. and assigned to The Burchell Nursery, Inc. Fruit: globose; uniform; medium-sized; dark red to orange red over $80-90 \%$ of surface with yellow-golden ground color; flesh firm, melting; very sweet with moderate acidity and very good to excellent flavor; ripens 17 May and similar to May Crest in Fowler. Tree: upright to upright spreading; vigorous; average to above average size; productive; flowers showy, large, light pink to very pale pink, self-fertile; leaf glands reniform, small; susceptible to bacterial spot ( $X$. arboricola $\mathrm{pv}$. pruni; formerly Xanthomonas pruni).

Burpeachtwo. Yellow-fleshed, firm, late-season, clingstone peach. Origin: Fowler, Calif., by John K. Slaughter and Timothy J. Gerdts. Autumn Lady x Summer Lady. USPP 12,157 issued 23 Oct. 2001 and assigned to The Burchell Nursery, Inc. Fruit: oblate to slightly oval; large; moderately uniform; $70 \%$ to $90 \%$ dark red to orange red over surface with yellow-golden ground color; flesh firm and fine; very sweet, mild acidity, with very good to excellent flavor; ripens 1 Aug., $7 \mathrm{~d}$ after Summer Lady in Fowler. Tree: upright-to-upright spreading; average to above average size; productive; flowers showy, large, light pink to dark pink, self fertile; leaf glands reniform, small; susceptible to bacterial spot.

Burpeachthree. Yellow-fleshed, firm, very late-season, freestone peach. Origin: Fowler, Calif., by John K. Slaughter, and Timothy J. Gerdts. Autumn Lady x Summer Lady. USPP 12,507 issued 2 Apr. 2002 and assigned to The Burchell Nursery, Inc. Fruit: oblate to oval; large; uniform; $60 \%$ to $90 \%$ covered with red blush with yellow-golden ground color; flesh is firm and fine; very sweet, mild acidity, and very good to excellent flavor; ripens 30 Aug. with Fairtime. Tree: upright-to-upright spreading; average to above average size; productive; flowers showy, large, light to medium pink; leaf glands reniform, small; susceptible to bacterial spot.

Burpeachfour. Yellow-fleshed, firm, late to very late-season, freestone peach. Origin: Fowler, Calif., by John K. Slaughter and Timothy J. Gerdts. Unnamed peach x Carnival. USPP 12,405 issued 12 Feb. and assigned to The Burchell Nursery, Inc. Fruit: oblate to oval; mediumlarge; uniform; 70-80\% of surface covered with a dark red blush with yellow-golden ground color; flesh is firm and fine; very sweet, mildly acidic and good to excellent flavor; ripens 28 Sept. and $8 \mathrm{~d}$ before Autumn Flame in Fowler, Calif. Tree: upright-to-upright spreading; average to above average size; productive; flowers showy, large, light to medium pink, self-fertile; leaf glands reniform, medium size.

Burpeachfive. Yellow-fleshed, firm, early midseason, freestone peach. Origin: Fowler, Calif., by John K. Slaughter and Timothy J. Gerdts. Unnamed peach selection $x$ Grand Diamond nectarine. USPP 12,505 issued 2 Apr. 2002 and assigned to The Burchell Nursery, Inc. Fruit: oblate to oval; medium-large; uniform; dark red to orange- red over $70 \%$ to $90 \%$ of surface with yellow-golden ground color; flesh firm, fine; very sweet, mildly acidic and very good to excellent flavor; ripens 3 July with Flamecrest in Fowler. Tree: upright to upright-spreading; average size; productive; flowers large, showy, light pink to medium pink, self-fertile; leaf glands reniform; highly susceptible to bacterial spot.

Burpeachsix. Yellow-fleshed, early season, firm, freestone peach. Origin: Fowler, Calif., by John K. Slaughter and Timothy J. Gerdts. Grand Diamond nectarine x June Lady. USPP 13,392 issued 24 Dec. 2002 and assigned to The Burchell Nursery, Inc. Fruit: globose; medium; $70 \%$ to $80 \%$ covered with dark red to orange-red blush and yellowgolden ground color; Flesh firm, fine, melting; sweet with moderate acidity, with good flavor; ripens June 18 in Fowler. Tree: upright-toupright spreading; average to above average size; productive; flowers nonshowy, medium, light pink to very pale pink; leaf glands reniform, small and opposite.

Burpeachseven. Yellow-fleshed, firm, late midseason, freestone peach. Origin: Fowler, Calif., by John K. Slaughter and Timothy J. Gerdts. Unnamed peach selection $\mathrm{X}$ unnamed nectarine selection. USPP 13,415 issued 24 Dec. 2002 and assigned to The Burchell Nursery, Inc. Fruit: oblate to slightly oval; medium-large; uniform; $80 \%$ to $90 \%$ dark red to orange-red with yellow-orange ground color; flesh very firm, fine dense; sweet, mildly acidic, good flavor; ripens 24 July in Fowler. Tree: upright 
to slightly spreading; vigorous; productive; flowers showy, large, light to medium pink, self-fertile; leaf glands reniform, medium, alternate.

Burpeacheight. Yellow-fleshed, firm, late-season, freestone peach. Origin: Fowler, Calif., by John K. Slaughter and Timothy J. Gerdts. Carnival x A48-70. USPP 12,834 issued 6 Aug. 2002 and assigned to The Burchell Nursery, Inc. Fruit: globose to somewhat oblate; medium; uniform; $80 \%$ to $90 \%$ deep crimson red blush with a yellowgolden ground color; flesh very firm, fine dense; sweet, mildly acidic, good flavor and balanced; ripens 30 Aug. 24 in Fowler. Tree: upright to upright spreading; vigorous; productive; flowers showy, large, light pink, self-fertile; leaf glands reniform, small.

Burpeachnine. Yellow-fleshed, very early season, firm, clingstone peach. Origin: Fowler, Calif., by John K. Slaughter and Timothy J. Gerdts. Rich Lady x Mayfire nectarine; USPP 13,494 issued 21 Jan. 2003 and assigned to The Burchell Nursery, Inc. Fruit: moderately oblate; medium-large; uniform; dark red over to pale yellow-white ground color; flesh dense; sweet, mildly acidic with good flavor; ripens 8 June in Fowler. and 10 d earlier than Rich Lady. Tree: upright; moderately vigorous; medium size; medium-dense; productive; flowers showy, large, light pink; leaf glands reniform, alternate; chilling requirement $\sim 550 \mathrm{~h}$.

Burpeachten. Yellow-fleshed, firm, midseason, clingstone peach. Origin: Fowler, Calif., by John K. Slaughter and Timothy J. Gerdts. Rich Lady x Mayfire. USPP 13,507 issued 21 Jan. 2003 and assigned to The Burchell Nursery, Inc. Fruit: oblate; medium-large; uniform; dark to light red blush with pale yellow ground color; flesh firm, dense; sweet, mildly acidic, good flavor; ripens 13 June in Fowler. Tree: moderately vigorous; productive; flowers showy, large, light to medium pink, selffertile; leaf glands reniform; chilling $600 \mathrm{~h}$.

Burpeacheleven. Yellow-fleshed, sub-acid, clingstone peach. Origin: Fowler, Calif., by John K. Slaughter and Timothy J. Gerdts. Unnamed peach $x$ unnamed peach. USPP 13,528 issued 28 Jan. 2003 an assigned to The Burchell Nursery, Inc. Fruit: moderately oblate; uniform; large; red to reddish-orange blush over $70 \%$ to $90 \%$ of surface with yellow-orange ground color; flesh firm, dense; sweet, sub-acid, very good flavor; ripens 22 Aug. in Fowler. Tree: upright; moderately vigorous; medium-large; medium-dense; productive; flowers nonshowy, small, light pink to dark pink; leaf glands reniform, small; chilling requirement $\sim 750 \mathrm{~h}$.

Burpeachtwelve. Yellow-fleshed, firm, late-season, clingstone peach. Origin: Fowler, Calif., by John K. Slaughter and Timothy J. Gerdts. Unnamed selection x A48-70. USPP 13,529 issued 28 Jan. 2003 and assigned to The Burchell Nursery, Inc. Fruit: oblate; large; uniform; yellow-orange to dark red blush over $40 \%$ to $70 \%$ of surface with yellow-orange ground color; flesh firm, dense; sweet, mildly acidic, good flavor; ripens 7 Oct. in Fowler. Tree: medium-large; moderately vigorous; productive; flowers showy, large, light to medium pink, selffertile; leaf glands globose; chilling $750 \mathrm{~h}$.

Burpeachthireteen. Yellow-fleshed, firm, late-season, freestone peach. Origin: Fowler, Calif., by John K. Slaughter and Timothy J. Gerdts. Unnamed selection x A48-70. USPP 13,583 issued 18 Feb. 2003 and assigned to The Burchell Nursery, Inc. Fruit: oblate; medium-large; uniform; yellow-orange to dark red blush over $40 \%$ to $70 \%$ of surface with pale yellow-orange ground color; flesh firm, dense; sweet, mildly acidic, good flavor; ripens 19 Sept. in Fowler. Tree: moderately vigorous; productive; upright; flowers showy, large, light to medium pink, selffertile; leaf glands reniform; chilling $750 \mathrm{~h}$.

Burpeachfourteen. Yellow-fleshed, very early season, clingstone peach. Origin: Fowler, Calif., by John K. Slaughter and Timothy J. Gerdts. Spring Gem X unnamed white-fleshed nectarine selection. USPP 14,342 issued 2 Dec. and assigned to The Burchell Nursery, Inc. Fruit: moderately oblate; uniform; large for early season; blush red to reddish-orange over $70 \%$ to $90 \%$ of surface with yellow-orange ground color; flesh firm, non melting, dense; mildly acidic, sweet with very good flavor; ripens 6 May, 14 d earlier than Spring Gem. Tree: upright; vigorous; medium-dense; medium-large size; productive; flowers showy, large, light pink, self-fertile; leaf glands are globose, alternate; chilling requirement $\sim 600 \mathrm{~h}$.

Burpeachfifteen. Yellow-fleshed, very late-season, freestone peach. Origin: Fowler, Calif., by John K. Slaughter and Timothy J. Gerdts. Unnamed selection $\mathrm{x}$ unnamed white-fleshed nectarine selection. USPP 14,454 issued 13 Jan. 2004 and assigned to The Burchell Nursery, Inc. Fruit: moderately oblate; large; uniform; reddish-orange to dark red blush over $75 \%$ to $90 \%$ of surface with yellow-orange ground color; flesh firm, dense, nonmelting; sweet, mildly acidic and very good flavor; ripens 29 Aug. in Fowler, Calif. Tree: upright; moderately vigorous; medium-large size; medium dense; productive; flowers showy, large, light pink, selffertile; leaf glands globose, alternate; chilling requirement $\sim 600 \mathrm{~h}$.

Burpeachsixteen. Yellow-fleshed, firm, early season, clingstone peach. Origin: Fowler, Calif., by John K. Slaughter and Timothy J. Gerdts. Selection A25.046 open pollinated. USPP 14,364 issued 9 Dec. 2003 and assigned to The Burchell Nursery, Inc. Fruit: oblate; medium-large; uniform; reddish-orange to dark red blush over $75 \%$ to $90 \%$ of surface with yellow-orange ground color; flesh firm, dense, nonmelting; sweet, mildly acidic, good flavor; ripens 8 June in Fowler. Tree: medium-large; moderately vigorous; productive; upright; flowers showy, large, light to medium pink, self-fertile; leaf glands globose; chilling $650 \mathrm{~h}$.

Burpeachseventeen. Yellow-fleshed, midseason, firm, nonmelting, clingstone peach. Origin: Fowler, Calif., by John K. Slaughter and Timothy J. Gerdts. Ross X unnamed peach selection. USPP 14,478 issued 20 Jan. 2004 and assigned to The Burchell Nursery, Inc. Fruit: moderately oblate; uniform; large; red blush with yellow-orange ground color; flesh firm, dense, nonmelting; sweet, mild, acidic, very good flavor; ripens 15 July and $\sim 8$ d earlier than Ross in Fowler. Tree: upright; moderately vigorous; medium-dense; productive; flowers showy, large, light to medium pink, self-fertile; leaf glands absent; chilling requirement $650 \mathrm{~h}$.

Burpeachnineteen. Yellow-fleshed, early season, clingstone peach. Origin: Fowler, Calif., by John K. Slaughter and Timothy J. Gerdts. Unnamed selection $\mathrm{x}$ unnamed white-fleshed nectarine selection. USPP 15,263 issued 26 Oct. 2004 and assigned to The Burchell Nursery, Inc. Fruit: oblate; uniform; large; $80 \%$ to $90 \%$ red blush with yellow-orange ground color; flesh firm, juicy, dense; sweet, mildly acidic, very good flavor; ripens 8 May in Fowler. Tree: upright; moderately vigorous; medium to large size; medium-dense; productive; flowers showy, large, light pink darkening to medium pink, self-fertile; leaf glands reniform, medium, alternate or occasionally opposite; chilling requirement $\sim 600$ h.

Burpeachtwenty. Yellow-fleshed, late-season, freestone peach. Origin: Fowler, Calif., by John K. Slaughter and Timothy J. Gerdts. Seedling of unnamed selection $\mathrm{X}$ white-fleshed nectarine selection. USPP 15,394 issued 30 Nov. 2004 and assigned to The Burchell Nursery, Inc. Fruit: oblate; uniform; large; $75 \%$ to $85 \%$ red blush over yellow-ground color; flesh firm, juicy, dense, melting; sweet and mildly acidic with very good flavor; ripens 9 Aug. in Fowler. Tree: upright; moderately vigorous; medium-large size; medium dense; productive; flowers showy, large, light pink to medium pink, self-fertile; leaf glands globose, mediumsmall, alternate; chilling requirement $\sim 700 \mathrm{~h}$.

Calara. Yellow-fleshed, very late-season, clingstone peach. Origin: Fowler Calif., by John K. Slaughter and Timothy J. Gerdts. Fayette X unnamed selection. USPP 15,496 issued 25 Jan. 2005 and assigned to the Burchell Nursery, Inc. Fruit: uniform; oblate; large; faint red flecking blush over 40-60\% over skin with yellow-orange undercolor; flesh firm, juicy, yellow, dense, nonmelting; ripens1 Oct. in Fowler and 5 d later than Autumn Lady. Tree: upright; medium-dense; moderately 
vigorous; medium-large; productive; flowers medium-large, showy, light pink, self-fertile; leaf glands reniform, alternate; chilling requirement estimated to be $700 \mathrm{~h}$.

Klamath. Yellow-fleshed, firm, nonmelting clingstone peach. Origin: Modesto, Calif., by Gary N. Zaiger, Leith M. Gardner, and Grant G. Zaiger. Seedling of two selections. USPP 15,557 issued 15 Feb. 2005. Fruit: globose; large to very large; very slight red blush with yellow ground color over most of surface; flesh firm, nonmelting; good for fresh eating with moderate juiciness; good flavor comparable to nonmelting clingstones; ripens $1 \mathrm{Aug}$. and/or 1 to 2 d earlier than Andross in Modesto. Tree: upright; vigorous; large; very productive; flowers nonshowy, medium, pink; leaf glands reniform, medium to large.

May Sweet. Yellow-fleshed, early season, firm, sub-acid, clingstone, peach. Origin: Modesto, Calif., by Chris F. Zaiger, Gary N. Zaiger, Leith M. Gardner, and Grant G. Zaiger. Seedling of two unnamed selections. USPP 12,410 issued 12 Feb. 2002. Fruit: nearly globose; medium to large; red blush over golden-yellow ground color; flesh firm, moderately juicy; excellent flavor; ripens 18 May and $22 \mathrm{~d}$ earlier than Sweet Gem. Tree: upright; vigorous; large; medium-dense; productive; flowers showy, large, light pink, self-fertile; leaf glands reniform, medium size.

PF 9A-007. Yellow-fleshed, early season, large, freestone peach. Origin: Coloma, Mich., by Paul J. Friday. Unknown seedling. USPP 15,498 issued 25 Jan. 2005. Fruit: ovoid; uniform; large; dark red overlying 90\%) of surface with a dark yellow ground color; flesh very firm to spongy, juicy; ripens in the early season in Coloma. Tree: upright to spreading; vigorous; medium-dense with close internodes; productive; flowers medium, nonshowy, dark pink, self-fertile; leaf glands absent.

PF Lucky 21. Yellow-fleshed, very firm, early midseason, freestone peach. Origin: Coloma, Mich., by Paul J. Friday. Unknown seedling. USPP 15,497 issued 25 Jan. 2005. Fruit: globose; uniform; large; 100 $\%$ red over skin surface; flesh very firm, crispy but melting, juicy, and yellow; ripens early midseason after Redhaven, from 1 Aug. in New Jersey and later in Michigan. Tree: semi-dwarf; moderately upright; dense with close internodes; very productive; flowers are medium size, nonshowy, dark pinkish-red, self- fertile; leaf glands round cupped, opposite.

PF 24 C. Yellow-fleshed, late-season, hardy, productive, freestone peach. Origin: Coloma, Mich., by Paul J. Friday. Unknown seedling. USPP 15,659 issued 15 Mar. 2005. Fruit: globose; large; 70\% dark red color over a yellow ground color; flesh extremely firm; very good flavor, pleasant and mild; ripens late season just before Cresthaven in Coloma. Tree: spreading; medium vigor; large; hardy; productive; flowers mediumlarge, pinkish-red, nonshowy; leaf glands elongated, shallow.

Sierra Gem. Yellow-fleshed, early midseason, freestone peach. Origin: Reedley, Calif., by Ron Toews. Chance seedling in a block of Fancy Lady. USPP 10,810 issued 2 Mar. 1999 and assigned to The Burchell Nursery, Inc. Fruit: globose; fairly uniform; large; flesh medium-fine; sweet, sub-acid, aromatic and excellent flavor; ripens 12 June and $7 \mathrm{~d}$ earlier than Fancy Lady in Reedley. Tree: upright to spreading; vigorous; productive; flowers small, pink; leaf glands reniform, opposite, small.

Snow Fall. White-fleshed, sub-acid, firm, very late-season, freestone peach. Origin: Modesto, Calif., by Chris F. Zaiger, Gary N. Zaiger, Leith M. Gardner, and Grant G. Zaiger. Seedling of two unnamed selections. USPP 11,568 issued 17 Oct. 2000. Fruit: nearly globose; large; light red to red blush over white to pinkish-white ground color; flesh firm, moderate juiciness; slightly aromatic; very good eating quality; ripens 5 Sept. and 7 d later than September Snow. Tree: upright; vigorous; large; medium-dense; productive; flowers large, showy, pink to light pink; leaf glands reniform, medium.

Snow Peak. White-fleshed, early season, low-chill, sub-acid, clingstone peach. Origin: Modesto, Calif., by Gary N. Zaiger, Leith M. Gardner, and Grant G. Zaiger. Seedling of two unnamed selections. USPP 14,479 issued 20, Jan. 2004. Fruit: globose; medium; attractive red skin color; flesh firm; very good mild flavor with, sweet, sub-acid; ripens 17 May, 2 d earlier than May Crest. Tree: upright; vigorous; large; medium-dense; productive; flowers large, showy, pink, self-fertile; leaf glands reniform, medium; chilling requirement $300 \mathrm{~h}$.

Spring Candy. Yellow-fleshed, firm, sub-acid, freestone peach. Origin: Le Grand, Calif., by L. Glen Bradford. Spring Bright nectarine x unnamed peach selection. USPP 14,677 issued 6 Apr. 2004. Fruit: globose; uniform; large; very deep red blending into moderate red-orange over $100 \%$ of surface; flesh rich, firm, crisp; sweet and sub-acid with very good flavor; ripens 24 June 24 and 12 d before Diamond Princess in Le Grand. Tree: upright; vigorous; medium; dense; productive; flowers very large, showy, purplish-pink, self-fertile; leaf glands reniform, alternate.

Sugarpeach. Yellow-fleshed, very large, extremely firm, midseason, clingstone peach. Origin: Le Grand, Calif., by L. Glen Bradford. August Red nectarine x Diamond Princess. USPP 15,259 issued 19 Oct. 2004. Fruit: globose; uniform; very large; very deep red blending into strong reddish-orange with brilliant yellow-ground color; flesh rich, firm, crisp, nonmelting; tasty blend of acid and sugar with very good flavor; ripens 16 July and $10 \mathrm{~d}$ later than Diamond Princess at LeGrand. Tree: spreading; vigorous; medium; dense; productive; flowers nonshowy, small, pale purplish- pink blending to strong purplish pink, self-fertile; leaf glands reniform, alternate and opposite, medium size.

Sugar Time. Yellow fleshed, early season, sub-acid, clingstone peach. Origin: Modesto, Calif., by Chris F. Zaiger, Gary N. Zaiger, Leith M. Gardner, and Grant G. Zaiger. Seedling of two unnamed selections. USPP 12,046 issued 4 Aug. 2001. Fruit: nearly globose; medium-large; deep red with small areas of medium-yellow to chrome-yellow ground color; flesh firm;, mild sweet and excellent flavor; ripens 25 June and $12 \mathrm{~d}$ after Sweet Gem. Tree: upright; vigorous; large; medium-dense; productive; flowers large, showy, pink to light pink, self-fertile; leaf glands reniform, small to medium, alternate.

Super Lady. Yellow-fleshed, early season, clingstone, low-chill peach. Origin: Modesto, Calif., by Gary N. Zaiger, Leith M. Gardner, and Grant G. Zaiger. Seedling of two unnamed selections. USPP 15,578 issued 22 Feb. 2005. Fruit: globose; medium to large; uniform; orange-red blush over yellow ground color; flesh firm, moderately juicy; good flavor; ripens very early, 3 weeks before Desert Gold and 1 before Super Rich. Tree: upright; large; vigorous; productive; flowers large, showy, pink; leaf glands globose, small; chilling requirement $350 \mathrm{~h}$.

Sweet Alice. Yellow-fleshed, early season sub-acid, clingstone, peach. Origin: Modesto, Calif., by Chris F. Zaiger, Gary N. Zaiger, Leith M. Gardner, and Grant G. Zaiger. Seedling of two unnamed selections. USPP 12,083 issued 11 Sept. 2001. Fruit: nearly globose; medium to large; light red to red with sunflower yellow to golden yellow ground color; flesh firm, moderately juicy; sweet, sub-acid with very good flavor; ripens 20 May or 20 d earlier than Sweet Gem. Tree: upright; vigorous; large; medium-dense; productive; flowers large, showy, pink to light pink, self-fertile; leaf glands reniform, medium.

Sweet Henry. Yellow-fleshed, firm, sub-acid, clingstone, late season peach. Origin: Modesto, Calif., by Gary N. Zaiger, Leith M. Gardner, and Grant G. Zaiger. Open-pollinated seedling. USPP 16,068 issued 25 Oct. 2005. Fruit: globose; large to very large; red over most of skin surface; flesh firm, meaty, moderately juicy; sub-acid and excellent flavor; stores very well; ripens 11 Aug. and $10 \mathrm{~d}$ after O'Henry. Tree: upright; large; vigorous; productive; flowers large, showy, pink, self-fertile; leaf glands reniform, small; chilling requirement is $\sim 750 \mathrm{~h}$.

Sweet Shasta. Yellow-fleshed, firm, low-chill, sub-acid, freestone peach. Origin: Modesto, Calif., by G.N. Zaiger, L.M. Gardner, and G.G. Zaiger. Seedling of two unnamed selections. USPP 14,515 issued 3 Feb. 2004. 
Fruit: globose; large; red over yellow ground color; flesh firm, meaty; flavor mild and very good; ripens 5-13 July and $18 \mathrm{~d}$ after Desertgold. Tree: upright; vigorous; large; medium-dense; productive; flowers are large, showy, pink, self-fertile; leaf glands reniform, small to medium; chilling requirement $\sim 350 \mathrm{~h}$.

White County. White fleshed, firm, sub-acid, freestone peach. Origin: Univ. of Arkansas, by John R. Clark and James N. Moore. Ark. 392 x Ark. 433; cross made in 1993; selected in 1997; tested as Ark. 678. USPP applied for. Fruit: round to oval; large; red blush covers $\sim 80 \%$ of skin surface; flesh very firm but softens when fully ripe to melting and fully white; freestone; sub-acid flavor and sweet with distinct white peach flavor; ripens 14 July at Clarksville, Ark. Tree: spreading; moderate vigor; productive; flowers showy, self-fertile; leaf glands reniform, four per leaf; resistant to bacterial spot.

White Rock. White fleshed, firm, sub-acid, clingstone peach. Origin: Univ. of Arkansas, by John R. Clark and James N. Moore. Ark. 371 x Ark. 367; cross made in 1993; selected in 1997; tested as Ark. 658. USPP applied for. Fruit: round, symmetrical with some fruits slightly oblate; medium; red blush covers $\sim 70 \%$ of skin surface; flesh nonmelting, very firm and remains firm when fully ripe and almost all white; clingstone; sub-acid flavor and sweet with light white peach flavor; ripens 25 June at Clarksville, Ark. Tree: spreading; moderate vigor; productive; flowers showy, self-fertile; leaf glands reniform, two per leaf; resistant to bacterial spot.

\section{PEACH ROOTSTOCK}

\section{T.G. Beckman}

USDA-ARS Southeastern Fruit and Tree Nut Research Laboratory Byron, Ga.

Barrier 1. A clonal, interspecific hybrid rootstock for peach. Origin: Firenze, Italy by G. Roselli, National Research Council of Italy Trees and Timber Institute. Prunus davidiana $\times$ P. persica; cross made in 1974; selected in 1983; tested as 420/1; introd. in 1987. Plant: Barrier 1 is propagated by micropropagation and hardwood cuttings. Unbudded tree is spreading; medium vigor; green leaves with reniform leaf glands; flowers showy, medium pink, self-fertile; fruit is small; freestone; ripening 120-130 d from bloom. Rootstock Performance: Trees budded on Barrier 1 display high vigor, though less than those on GF677; tolerant of droughty or calcareous soils; suitable for replant situations; productive and resistant to root-knot nematodes (Meloidogyne species); susceptible to crown gall (Agrobacterium tumefaciens).

Controller $5^{\mathrm{TM}}$. A clonal, interspecific hybrid rootstock for peach. Origin: Univ. of California and USDA-ARS by T. DeJong, D. Ramming, S. Johnson, and J. Doyle. Prunus salicina X P. persica; tested as K146-43; introd. in 2004. USPP 15,228; 12 Oct. 2004. Plant: Controller $5^{\mathrm{TM}}$ is propagated by hardwood cuttings. Unbudded tree is upright to semiupright; vigorous; green leaves with reniform leaf glands; flowers showy, light pink, sterile. Rootstock performance: Trees budded on Controller $5^{\mathrm{TM}}$ display reduced vigor, ca. $50 \%$ to $60 \%$ of those budded on Nemaguard which significantly reduces pruning costs and use of ladders; less resistant to root-knot nematodes than Nemaguard.

Controller 9тм. A clonal, interspecific hybrid rootstock for peach. Origin: Univ. of California and USDA-ARS by T. DeJong, D. Ramming, S. Johnson, and J. Doyle. Prunus salicina X P. persica; tested as P30-135; introd. in 2004. USPP 15,225; 12 Oct. 12 2004. Plant: Controller 9TM is propagated by hardwood cuttings. Unbudded tree is upright to semiupright; vigorous; green leaves with mostly reniform leaf glands; flowers showy, light pink, sterile. Rootstock performance: Trees budded on Controller $9^{\mathrm{TM}}$ display slightly reduced vigor, $~ 90 \%$ of those budded on Nemaguard which reduces pruning costs and use of ladders; less resistant to root-knot nematodes than Nemaguard.
Krymsk $2^{\mathrm{TM}}$. A clonal, interspecific hybrid rootstock for peach. Origin: Krymsk, Russia by G. Eremin, Vavilov Research Institute. Prunus incana xP. tomentosa; selected in 1977; tested as VSV-1. USPP 15,957; 13 Sept. 2005. Plant: Krymsk $2^{\mathrm{TM}}$ is propagated by micropropagation, hardwood or softwood cuttings, and layering. Unbudded tree is semi-upright; lowmoderate vigor; green leaves. Rootstock performance: Trees budded to Krymsk $2^{\mathrm{TM}}$ are more cold, heat and drought tolerant than trees on peach seedling. Budded tree size is $\sim 60 \%$ of that on peach seedling.

\section{PEAR}

Joseph D. Postman

USDA-ARS National Clonal Germplasm Repository

Corvallis, Ore.

Shenandoah. A large-fruited, mid-late season pear with spicy, aromatic flavor, long storage life, and moderate resistance to fire blight. Origin: Kearneysville, W.VA., by R.L. Bell and T. van der Zwet, USDA-ARS Appalachian Fruit Research Station in collaboration with The Ohio State Univ.. Max Red Bartlett x US 56112; cross made in 1977 by T. van der Zwet and R.C. Blake; selected in 1985 by R.L. Bell; tested as US 78304-057; introd. in 2003. Fruit: Oblong-ovate-pyriform; moderately large, $\sim 235 \mathrm{~g}$, averaging $72 \mathrm{~mm}$ diameter, $92 \mathrm{~mm}$ long; skin light-green becoming yellow-green and glossy when ripe with $10 \%$ to $25 \%$ red blush; slight tan russet at calyx end and somewhat conspicuous lenticels; stem upright, curved, medium length $(\sim 25 \mathrm{~mm})$ and thickness $(\sim 3 \mathrm{~mm})$; flesh moderately fine, juicy, and buttery, with small grit cells near the core and under the skin, similar to Bartlett; flavor sweet and aromatic, slightly acid, improving to subacid after 2 months storage; harvest maturity similar to Beurre d'Anjou, 3 weeks after Bartlett; keeps for 16 weeks in common storage; late-harvested fruit develops acceptable eating quality without cold storage, but fruit removed from cold-storage after 1-4 months softens to eating quality more quickly. Tree: moderately vigorous with upright-spreading habit; midseason bloom, similar to Bartlett; moderately precocious cropping; no evidence of biennial bearing; very productive with yields comparable to Beurre d'Anjou, and better than Bartlett; moderately resistant but not immune to fire blight (Erwinia amylovora).

\section{PECAN}

\section{L.J. Grauke and T.E. Thompson}

USDA-ARS Southern Plains Agricultural Research Center College Station, Tex.

Excel Precocious. Prolific, pecan seedling. Origin: A.L. Clough Orchard, Blackshear, Ga., by A.L. Clough. Grown from nut of a local tree used as rootstock; selected in 1990 and thought to be 20-25 years old at that time. USPP pending. Nut: elliptic with an obtuse apex and asymmetrical, obtuse base, round in cross section; 45 nuts/lb, with 51\% kernel; similar in size and shape to Desirable, but with thicker shell as in Gloria Grande; borne in clusters of 3-5; kernels cream to golden in color; broad, tapering dorsal ridge with deep, relatively narrow dorsal grooves; ventral groove often forming prominent basal cleft; mature early and are harvestable the first week in October, 2 weeks after Pawnee. Tree: leaflets small, widely spaced on rachis, and buds widely spaced on shoot, making the foliage appear sparse; protogynous with midseason pistil receptivity and late season pollen shed; bloom is later than Stuart; pecan scab (Fusicladosporium effusum) has not been found on nuts either in the unmanaged orchard of origin or a managed orchard at Tifton (Ga.); precocious, bearing at 3 years; prolific, producing up to $50 \mathrm{lbs}$ on 7 -year-old trees.

Die Güet. High-quality native pecan. Origin: Selected by Alfred J. Stein, from his land on the Medina River, north of Castroville, Medina County, Texas about 1910. Harvested for family use and has been propagated locally since 1920. The name means "good" in Alsatian. Nut: oblong 
elliptic with acute apex; base rounded with slight point; 68 nuts/lb; 57\% kernel; similar in shape to Curtis; kernels golden in color, with deep, medium-wide dorsal grooves that do not trap packing material; no secondary grooves; dorsal ridge relatively straight, only slightly tapered at apex; ventral groove medium, often forming slight basal cleft; shells easily into full halves with excellent quality; mature early, 5-7 d after Pawnee. Tree: growth is upright, with dark green foliage.

Starking ${ }^{\circledR}$ Southern Giant ${ }^{\mathrm{TM}}$. See Silverback (Register of new fruit and nut varieties. List 42. HortScience 39:1513-1514. 2004). Being propagated by Stark Bros. Nursery, Louisiana, Mo.

Waco. High-quality pecan for the western region of North America. Origin: USDA-ARS Brownwood, Tex., by T.E. Thompson, L.J. Grauke and L. Lombardini. Cheyenne x Sioux; cross made in 1975; tested as 75-5-6; released cooperatively by USDA-ARS and the Texas Agricultural Experiment Station in 2005. Nut: elliptic with an obtuse apex and an acuminate (pointed) base; laterally compressed in cross section; 53 nuts/lb (up to 38 nuts/lb), with $56 \%$ kernel; kernels cream to golden in color; wide, nontrapping dorsal grooves and rounded dorsal ridge; shells out easily into very attractive full halves. Tree: bud growth commences shortly before Desirable in the spring; leaves are characterized by large leaflets, a feature common to other members of this cross family (Nacono and 74-5-60); trees are protandrous, with early to midseason pollen shed and midseason pistil receptivity (similar to Caddo and Cheyenne); should be a good pollinizer for, and be well pollinized by Wichita, Choctaw, Hopi, and Kanza; more susceptible to pecan scab than Desirable; moderately susceptible to the yellow aphid complex; medium precocity, similar to Pawnee; comparable in vigor to Desirable and less vigorous than Nacono; form is improved over the willowy, weak growth of Cheyenne; nuts/cluster comparable to Desirable and less than Nacono or Pawnee; time of nut maturity is midseason at College Station, Texas (11-21 Oct.), or $\sim 8 \mathrm{~d}$ before Desirable.

\section{PLUM AND PLUM HYBRIDS}

\section{David W. Ramming}

USDA-ARS Crop Diseases, Pests and Genetics, San Joaquin Valley Agricultural Sciences Center, Parlier, Calif.

92-95-99. A late midseason, red skin European plum for fresh market. Origin: Delano, Calif., by Timothy F. Bourne. Sugar x President; cross made in 1993; selected in 1996. USPP 15,950 issued 13 Sept. 2005; assigned to Sunview Vineyards of California, Inc. Fruit: large, $40 \mathrm{~mm}$ diameter, $52 \mathrm{~g}$; oval; skin bright red; flesh yellow-orange; firm; very sweet, $21.9 \%$ SS; clingstone; ripe 22 to 29 July, one week after Sugar. Tree: vigorous; upright; very productive; self-infertile; anthers yellow; blooms 17 to 28 Mar. in Delano.

August Giant. A midseason, freestone, dark red skin, yellow-flesh Japanese plum. Origin: Parlier, Calif., by Harry Nakata. Bud sport of Mid Red plum. USPP 15,580; issued 22 Feb. 2005. Fruit: large, 62-68 $\mathrm{mm}$ diameter; oval; skin dark red, medium thickness; flesh golden; freestone; ripe 28 to 30 Aug., one week after Mid Red. Tree: medium size; good vigor; upright; good regular production; self-fertile; anthers yellow; blooms 28 Feb. to 8 Mar. in Parlier.

August Yummy®. A mid-late season, dark red skin, yellow-flesh Japanese plum. Origin: Le Grand, Calif., by Lowell G. Bradford. Grand Rosa X unknown plum; cross made in 1996. USPP 14,247; issued 21 Oct. 2003. Fruit: large, $67 \mathrm{~mm}$ diameter, $167 \mathrm{~g}$; globose to oblate; skin is dark red, medium thickness; flesh light yellow with some red under skin; very firm; $18 \%$ to $21 \%$ SS; clingstone; ripe 11 to 15 Aug., three weeks after Grand Rosa. Tree: medium size; vigorous; upright; very productive; self-infertile; anthers yellow; blooms 20 Feb. to 5 Mar. in Le Grand.
Big Red. A mid-late season, red skin, yellow to yellow-red flesh Japanese plum. Origin: Modesto, Calif., by Gary N. Zaiger, Leith M. Gardner, and Grant G. Zaiger. 9GF78 = (selection with King David, Queen Ann, Casselman parents) open pollinated; selected in 1991. USPP 14,465; issued 13 Jan. 2004. Fruit: very large, $66 \mathrm{~mm}$ diameter, $189 \mathrm{~g}$; globose to slightly elongated; skin red, medium thickness; flesh yellow to yellow-red; firm; $16 \%$ SS; clingstone; ripe 1 to 6 Aug., 1 week after Friar. Tree: large size; vigorous; upright; heavy production; self-infertile; anthers yellow; blooms 28 Feb. to 13 Mar. in Modesto; chilling requirement $850 \mathrm{~h}$.

D6N-72. An early-ripening European plum for drying. Origin: Parlier, Calif., by James F. Doyle, Carolyn J. DeBuse, and Theodore M. DeJong, Univ. of California. Improved French x Tulare Giant; cross made in 1992. USPP 15,547 issued 8 Feb. 2005; assigned to the Univ. of California. Fruit: large, 37- to $45-\mathrm{mm}$ diameter, 35 to $47 \mathrm{~g}$, oval; skin light purple, medium thickness; flesh amber-yellow; firm; sweet with low acidity, $19 \%$ SS; nearly freestone; ripe 8 Aug., 13 d ahead of Improved French. Tree: medium size; average vigor; upright-spreading; very productive; precocious; regular bearer; self-fertile; anthers golden-yellow; blooms 1-11 Mar., 9 d before Improved French.

Emerald Gem. A midseason, complex interspecific hybrid with yellow, glabrous skin. Origin: Modesto, Calif., by Gary N. Zaiger, Leith M. Gardner, and Grant G. Zaiger. 29EB323 $=[$ Friar x 4G1180 $=($ Red Beaut $x$ unknown apricot $)] \times 4 G 1180=($ Red Beaut $x$ unknown apricot $)$; selected in 1987. USPP 14,599; issued 16 Mar. 2004. Fruit: medium, 54 mm diameter, $102 \mathrm{~g}$; globose to slightly oblate; skin yellow with slight speckling, medium thickness; flesh yellow; firm; good sugar and acid balance, 20\% SS; clingstone; ripe 1 to 8 July, 18 d before Flavor Queen. Tree: large size; vigorous; upright; heavy production; self-infertile; white petals; anthers yellow-red; blooms 16 to $28 \mathrm{Feb}$. in Modesto; chilling requirement $700 \mathrm{~h}$.

Flavor Wynne. An early season, complex interspecific hybrid plum with reddish-maroon, glabrous skin. Origin: Modesto, Calif., by Gary N. Zaiger, Grant G. Zaiger and Leith M. Gardner. 57EC493 = (third generation seedling selection from Red Beaut o.p. $) \times 59 E C 558=[(\operatorname{Red}$ Beaut o.p.) $x$ unknown apricot]; selected in 1990. USPP 15,762; issued 17 May 2005. Fruit: medium to large, $54 \mathrm{~mm}$ diameter, $125 \mathrm{~g}$; globose with slightly enlarged apex; skin reddish-maroon, medium thickness; flesh yellow; slightly firmer than Santa Rosa, very good flavor; $16 \%$ SS; semi-freestone; ripe 16 to 21 June, with Santa Rosa. Tree: large size; vigorous; upright; regular production; self-infertile; white petals; anthers yellow; blooms 20 to $28 \mathrm{Feb}$. in Modesto; chilling requirement $800 \mathrm{~h}$.

Holiday. A late season, yellow-green skin, yellow-flesh Japanese plum. Origin: Modesto, Calif., by Gary N. Zaiger, Leith M. Gardner, and Grant G. Zaiger. 46ED305 = (second generation seedling King David o.p.) x Autumn Pride; selected in 1991. USPP 15,553; issued 8 Feb. 2005. Fruit: large, 74 mm diameter, 202 g; ovate; skin yellow-green, medium thickness; flesh yellow; firm; good eating quality and slightly tart near skin; $19 \%$ SS; clingstone; ripe 23 to 29 Oct., 30 d after Autumn Pride. Tree: large size; vigorous; upright; productive with regular production; self-infertile; anthers red; blooms 25 Feb. to 5 Mar. in Modesto; chilling requirement $650-700 \mathrm{~h}$.

Honey Sweet. A transgenic European plum containing plum pox virus coat protein gene. Origin: Kearneysville, W.Va., by Ralph Scorza, Michel Ravelonandro, and Dennis Gonsalves, USDA-ARS Appalachian Fruit Research Station. Bluebyrd o.p. seedling transformed with A grobacterium tumefaciens. USPP 15,154; issued 21 Sept. 2004; assigned to U.S. Dept. of Agriculture, Insitut National de la Recherche Agronomique and Cornell Research Foundation, Inc. Fruit: medium to large, 43-45 $\mathrm{mm}$ diameter, $60 \mathrm{~g}$; oval; skin blue, medium thickness; flesh yellow; firm; sweet, $21.5 \%$ SS; freestone; ripe mid August to early September in Kearneysville. Tree: large size; vigorous; upright; productive; blooms late March to mid-April; resistant to plum pox virus. 
Mann. An early season, yellow-green skin Japanese plum resistant to canker diseases. Origin: Warrior, Ala., by Bobby W. Mann. Chance seedling found in 1988. USPP 15,014; issued 13 Jul. 2004. Fruit: medium to large, $50 \mathrm{~mm}$ diameter, 78-93 g; globose; skin amber-yellow, medium thickness; tart; flesh yellow, juicy and crisp; clingstone; ripe $3^{\text {rd }}$ week June to $2^{\text {nd }}$ week July in Blount County, Ala. Tree: large size; very vigorous; spreading; very productive; partial self-fertile; anthers yellow; blooms 12-26 Mar.; chilling requirement 400-750 h; resistant to canker and trunk diseases.

Marcia's Flavor. A midseason, complex interspecific hybrid with red, glabrous skin. Origin: Modesto, Calif., by Gary N. Zaiger, Leith M. Gardner, and Grant G. Zaiger. 16GG159 $=[P$. salicina $\times(P$. salicina $\times P$. armeniaca) ] x Flavor Gem interspecific; selected in 1993. USPP 15,088; issued 17 Aug. 2004. Fruit: large, 61 mm diameter, 176 g; globose; skin red, medium thickness; flesh yellow; firm; excellent flavor; $19 \% \mathrm{SS}$; clingstone; ripe 23 to 29 July, 20 d before Flavor Gem. Tree: large size; vigorous; upright; productive; self-infertile; white petals; anthers yellow; blooms 15 to 26 Feb. in Modesto; chilling requirement is $650 \mathrm{~h}$.

Plumsweetone. An early season, purple over yellow skin, yellow-flesh Japanese plum. Origin: Le Grand, Calif., by Lowell G. Bradford. Ambra open pollinated; seed collected in 1997. USPP 14,219; issued 7 Oct. 2003. Fruit: medium, $65 \mathrm{~mm}$ diameter, $128 \mathrm{~g}$; oblate; skin two tone purple over yellow, medium thickness, moderate astringency; flesh light yellow; very firm; $19 \%$ SS; clingstone; ripe 29 June to 12 July, 1 week before Blackamber. Tree: medium size; vigorous; upright; very productive; self-infertile; anthers yellow; blooms 23 Feb. to 5 Mar. in Le Grand.

Plumsweettwo. A midseason, dark purplish-red skin, red-flesh Japanese plum. Origin: Le Grand, Calif., by Lowell G. Bradford. Unk. plum x Black Noble; cross made in 1996. USPP 14,196; issued 30 Sept. 2003. Fruit: medium, $64 \mathrm{~mm}$ diameter, $130 \mathrm{~g}$, globose to slightly oblate; skin dark purplish-red, medium thickness, moderate astringency; flesh deep red; very firm; $21 \%$ to $23 \% \mathrm{SS}$; clingstone; ripe 20 to $30 \mathrm{July}, 40 \mathrm{~d}$ after Black Noble. Tree: large; vigorous; spreading; productive; self-infertile; anthers yellow; blooming 24 Feb. to 5 Mar. in Le Grand.

Plumsweetthree. A mid-late season, interspecific Japanese plum hybrid with red-yellow, glabrous skin. Origin: Le Grand, Calif., by Lowell G. Bradford. (Bradgreen x o.p.) x o.p., collected seed in 1997. USPP 15,235; issued 12 Oct. 2004. Fruit: medium, 68-mm diameter, $170 \mathrm{~g}$; globose with some elongated noses; skin dark reddish-orange streaking over yellow, medium thickness, glabrous; flesh light yellow; firm; crisp; very sweet and slightly acidic with hint of apricot; $20 \%$ SS; semi-freestone; ripe 7-20 Aug. Tree: medium size, medium vigor, spreading; productive, self-infertile, white petals, anthers light yellow, blooming 28 Feb. to 9 Mar. in Le Grand.

Ruby Queen. A late season, red skin, red-flesh Japanese plum. Origin: Byron, Ga., by Jim M. Thompson and W.R. Okie. BY7607-10 = (Frontier x Redroy) x o.p.; seed planted 1982; selected 1985; tested as BY815570; released 4 Jun. 2004. Fruit: medium, 50-mm diameter, round; skin is dark red to reddish-black; flesh is red, firm; outstanding flavor; high antioxidants; clingstone; ripe mid-July, 3-4 weeks after Santa Rosa and Morris. Tree: moderately vigorous; somewhat upright; very productive; self-infertile; blooms with Methley; chilling requirement $750 \mathrm{~h}$; moderately resistant to bacterial leaf spot and bacterial canker diseases.

SeptemberYummy®. A late-season, dark red skin, yellow-flesh Japanese plum. Origin: Le Grand, Calif., by Lowell G. Bradford. Unknown plum x Bradgreen; cross made in 1996. USPP 14,220; issued 7 Oct. 2003. Fruit: medium, 64 mm diameter, 162 g; globose to slightly oblong; skin dark red, medium thickness, slight astringency; flesh yellow with some red under skin; very firm; $19 \%$ SS; semi-freestone; ripe 10 to 25 Sept., $50 \mathrm{~d}$ after Fortune. Tree: large size; vigorous; upright; very productive; self-infertile; anthers yellow; blooms 20 Feb. to 2 Mar. in Le Grand.
Splash. An early season, complex interspecific hybrid plum with yellow, glabrous skin. Origin: Modesto, Calif., by Gary N. Zaiger, Grant G. Zaiger, and Leith M. Gardner. 29EB323 $=[$ Friar x 4G1180 $=($ Red Beaut X unknown apricot $)] \times 4 G 1180=($ Red Beaut $X$ unknown apricot $)$; selected in 1987. USPP 14,583; issued 9 Mar. 2004. Fruit: small to medium, $50 \mathrm{~mm}$ diameter, $85 \mathrm{~g}$; globose with slight point; skin yellow, medium thickness; flesh yellow; firm good sugar and acid balance, $18 \% \mathrm{SS}$; clingstone; ripe 21 to 27 June, $28 \mathrm{~d}$ after Red Beaut. Tree: large size; vigorous; upright; heavy production; self-infertile; white petals; anthers red; blooms 25 Feb. to 6 Mar. in Modesto; chilling requirement $650 \mathrm{~h}$.

Spring Flavor. An early season, complex interspecific hybrid plum with reddish-maroon, glabrous skin. Origin: Modesto, Calif., by Gary N. Zaiger, Grant G. Zaiger, and Leith M. Gardner. 288LF477 $=(\mathrm{Geo}$ Pride plumcot $\mathrm{X}$ interspecific from $P$. salicina, $P$. armeniaca, $P$. persica) x 391LD449 = (interspecific from Modesto apricot, plumcot 4G1180, unknown apricot); selected in 1998. USPP 14,571;issued 2 Mar. 2004. Fruit: large, 51-mm diameter, $119 \mathrm{~g}$; globose and slightly flattened; skin reddish-maroon, medium thickness; flesh yellow with slight red under skin; firm; mild sweet, $12 \%$ SS; clingstone; ripe 22 to 28 May, $7 \mathrm{~d}$ before Red Beaut plum. Tree: large size; vigorous; upright; heavy production; self-infertile; white petals; yellow anthers; blooms 16 to 25 Feb. in Modesto; chilling requirement 450-500 h.

Suplumtwentyfive. A low chill, black skin, amber-flesh Japanese plum. Origin: Wasco, Calif., by David W. Cain and Terry A. Bacon. 90P-001 $=$ (Suplumeighteen $\times$ Ambra $) \times$ unknown low-chill plum; cross made in 1996. USPP 15,888 ; issued 19 July 2005; assigned to Sun World International, Inc. Fruit: large, 55-58 mm diameter, 99 g; round; skin purple to black, medium thickness, slightly acidic; flesh amber; firm; moderately juicy; slightly acidic, 14\% SS; clingstone; ripe 5-15 June in Kern County, Calif. Tree: medium size; vigorous; upright-spreading; heavy and regular production; anthers yellow-orange; blooms 5 to 12 Feb. in Coachella Valley, Calif.; chilling requirement $200 \mathrm{~h}$.

Suplumtwentysix. An early season, reddish-black skin, amber-flesh Japanese plum. Origin: Wasco, Calif., by Bruce D. Mowrey, David W. Cain, and Carlos D. Fear. Ambra x 438-432 = (Queen Rosa $\times$ Black Beaut); cross made in 1990; selected in 1993; tested as 93P-003. USPP 15,976; issued 20 Sept. 2005; assigned to Sun World International, Inc. Fruit: large, 61-mm diameter, $115 \mathrm{~g}$; round to slightly flattened; skin reddish-black, medium-thin, mildly tart; flesh amber, juicy; sweet-tart, $15 \%$ SS; clingstone; ripe 23 May to 2 June, $16 \mathrm{~d}$ before Black Beaut. Tree: medium size; vigorous; upright-spreading; productive; self-infertile; anthers yellow with red highlights; blooms 26 Feb. to 1 Mar. in Wasco; chilling requirement $650 \mathrm{~h}$.

Suplumtwentyseven. An early season, black skin, yellow-amber flesh Japanese plum. Origin: Wasco, Calif., by David W. Cain and Terry A. Bacon. 91P-060 x Suplumtwentythree; cross made in 1997; selected in 2000. USPP 16,006; issued 27 Sep. 2005; assigned to Sun World International, Inc. Fruit: large, 66-mm diameter, $152 \mathrm{~g}$; round to slightly oblate; skin black, medium thickness, acid; flesh yellow-amber; very firm; $15 \%$ SS; clingstone; ripe 5-15 June, with Black Beaut. Tree: medium size; moderate vigor; moderately upright; productive; self-infertile; anthers orange; blooms 23 to 28 Feb. in Wasco; chilling requirement $600 \mathrm{~h}$.

Suplumtwentyeight. An early season, black skin, red-flesh Japanese plum. Origin: Wasco, Calif., by Bruce D. Mowrey, David W. Cain, and Terry A. Bacon. 91P- $\mathrm{x}$ unknown plum selection; cross made in 1993. USPP 14,938; issued 22 June 2004; assigned to Sun World International, Inc. Fruit: large, 62-65 mm diameter, $155 \mathrm{~g}$; round to slightly oblate; skin purple to black, medium thickness; flesh red; firm; bland-sweet to sweet, $18 \%$ SS; clingstone; ripe 16-26 June with Santa Rosa. Tree: medium size; vigorous; upright-spreading; productive; somewhat self-fertile; anthers orange; blooms 1 to 4 Mar. in Wasco; chilling requirement $650 \mathrm{~h}$. 
Suplumtwentynine. An early season, black skin, red-flesh Japanese plum. Origin: Wasco, Calif., by David W. Cain and Terry A. Bacon. 562-053 $=($ Santa Rosa $\times$ Suplumeighteen $) \times$ 90P-055 $=($ Suplumfifteen o.p.); cross made in 1997; selected in 2000. USPP 14,880; issued 8 June 2004; assigned to Sun World International, Inc. Fruit: large, 65-mm diameter, $140 \mathrm{~g}$; round; skin purple to black, medium thickness, acidic; flesh pink to red; firm; mildly sweet, $17 \%$ SS; clingstone; ripe 25 June to 4 July with Blackamber. Tree: medium size; vigorous, uprightspreading; productive; somewhat self-fertile; anthers yellow-orange with orange-red highlights; blooms 28 Feb. to 3 Mar. in Wasco; chilling requirement $600 \mathrm{~h}$.

Suplumthirtythree. A midseason, very large, red skin, pink-flesh Japanese plum. Origin: Wasco, Calif., by Bruce D. Mowrey and Terry A. Bacon. $90 \mathrm{P}-068=($ Midsummer $\times 295-198) \times 90 \mathrm{P}-064=($ Suplumsix $\times$ Suplumeleven); cross made in 1994. USPP 15,068; issued 3 Aug. 2004; Assigned to Sun World International, Inc. Fruit: very large, $70-\mathrm{mm}$ diameter, $215 \mathrm{~g}$; round; skin red, medium thickness, acidic; flesh pink, firm, fine texture; sweet-tart, 17\% SS; semi-freestone; ripe 1-12 Aug., $30 \mathrm{~d}$ after Fortune. Tree: medium size; vigorous; upright-spreading; productive; somewhat self-fertile; anthers yellow-orange; blooms 1-6 Mar. in Wasco; chilling requirement $750 \mathrm{~h}$.

Suplumthirtyfour. A late season, red skin, yellow-flesh Japanese plum. Origin: Wasco, Calif., by Bruce D. Mowrey, David W. Cain, and Terry A. Bacon. 90P-072 = (Queen Ann x Simka) $x$ unknown plum selection; cross made in 1993. USPP 14,881; issued 8 Jun. 2004; assigned to Sun World International, Inc. Fruit: large, 60-65 mm diameter, $130 \mathrm{~g}$; round with slight apex; skin red, medium thickness, mildly tart to neutral; flesh yellow-orange; firm; sweet with low acid, $19 \%$ SS; clingstone; ripe 8 to 30 Oct., 18 d after October Sun. Tree: medium size; vigorous; uprightspreading; productive; somewhat self-fertile; anthers yellow-orange; blooms 2 to 5 Mar. in Wasco; chilling requirement $750 \mathrm{~h}$.

Suplumthirtyfive. An early season, black skin, amber-flesh Japanese plum. Origin: Wasco, Calif., by Bruce D. Mowrey, David W. Cain, and Terry A. Bacon. 90P-063 = (Suplumfifteen X Suplumeleven $)$ x 91P-083; cross made in 1994. USPP 15,897; issued 26 July 2005; assigned to Sun World International, Inc. Fruit: large, 66-mm diameter, $160 \mathrm{~g}$; rounded oblate; skin black, medium thickness, mildly bitter; flesh amber; firm; crisp and juicy; $17 \%$ to $19 \%$ SS; semi-freestone; ripe 16 to 22 June, with Santa Rosa. Tree: medium size; moderately vigorous; upright-spreading; heavy and consistent production; anthers yellow; blooms 27 Feb. to 2 Mar. in Bakersfield, Calif.; chilling requirement $650 \mathrm{~h}$.

Sweetcot. An early season interspecific Japanese plum apricot hybrid with dark purple, pubescent skin. Origin: Le Grand, Calif., by Lowell G. Bradford. Angeleno plum x unknown apricot; cross made in 1996. USPP 15,652; issued 15 Mar. 2005. Fruit: medium, 54-57 mm diameter, $102 \mathrm{~g}$; round to slightly oblate; skin dark purple with pubescence like an apricot, medium thickness; flesh orange-yellow; very firm, crisp; very sweet with moderate to low acid, $20 \%$ to $24 \%$ SS; clingstone; ripe 22 June to 1 July, 30 d before Angeleno. Tree: medium size; medium vigor; upright; apricot-like leaves; productive; self-infertile; white petals with pink edges; anthers purplish-pink over pale yellow; blooms 1 to 9 Mar., 1 week later than Santa Rosa.

Yummy®crisp. A midseason, black skin, orange-yellow flesh Japanese plum. Origin: Le Grand, Calif., by Lowell G. Bradford. Unnamed black plum $x$ o.p.; seed collected in 1997. USPP 14,237; issued 14 Oct. 2003. Fruit: medium, 59-mm diameter, $130 \mathrm{~g}$; globose to slightly oblong; skin black, medium thickness, slight astringency; flesh orange-yellow with some pink under skin; very firm; $20 \%$ to $24 \%$ SS; clingstone; ripe 25 July to 20 Aug. Tree: medium size; vigorous; upright; very productive; selfinfertile; anthers orange-yellow; blooms 18 to 28 Feb. in Le Grand.

Yummy®gem. An early season, purple skin, yellow-flesh Japanese plum. Origin: Le Grand, Calif., by Lowell G. Bradford. 7P865 = (Purple Majesty o.p.) X o.p.; seed collected in 1993. USPP 15,809; issued, 28 Jun. 2005. Fruit: medium to small, 50-57 mm diameter, $108 \mathrm{~g}$; oval to obovate; skin deep purplish red, medium thickness, somewhat astringent; flesh light greenish-yellow; firm, crisp; good eating quality, solids 16-18\% SS; clingstone; ripe 12 to 21 June, $12 \mathrm{~d}$ before Purple Majesty. Tree: large size; vigorous; spreading; very productive; self-infertile; anthers orange-yellow; blooms 14 to 26 Feb. in Le Grand.

\section{PLUM ROOTSTOCK}

\section{T.G. Beckman}

USDA-ARS Southeastern Fruit

and Tree Nut Res. Laboratory, Byron, Ga.

Barrier 1. Compatible with Japanese plums. Described under Peach Rootstock.

Controller $5^{\mathrm{TM}}$. Compatible with Japanese plums. Described under Peach Rootstocks

Controller 9 ${ }^{\mathrm{TM}}$. Compatible with Japanese plums. Described under Peach Rootstock.

Krymsk 2 $^{\text {TM }}$. Compatible with European plums. Described under Peach Rootstock.

\section{RASPBERRY}

\section{Hugh Daubeny}

Agriculture and Agri-Food Canada,

Pacific Agriculture Research Centre, Agassiz, B.C.

Aita. An early ripening floricane fruiting raspberry adapted to Estonia. Origin: Polli Horticultural Centre, Estonia, by J. Parkseep and A. Libek. Nr. 2-64-24 (Superlative x Novost Kuzmina) x Glen Clova; cross made in 1964; tested as Polli 1; registered in 2003. Fruit: large; round; light red; drupelets cohere firmly; easy to harvest. Plant: relatively high yield; moderate vigor; light green primocanes with weak spines; light brown floricanes; sufficiently winter hardy for Estonia; resistant to anthracnose (Elsinoe veneta); susceptible to cane blight (Leptosphaeria coniothyrium).

Alvi. A late ripening, high yielding floricane fruiting raspberry adapted to Estonia. Origin: Polli Horticultural Centre, Estonia, by J. Parkseep and A. Libek. Nr. 67-60-12 (Golden Queen X Spirina Belaya) x Novost Kuzmina; cross made in 1964; tested as Polli 2; registered in 2003. Fruit: large; conical; drupelets cohere firmly; good quality; late ripening. Plant: high yield; moderate vigor; primocanes light green with few spines; floricanes greyish brown; winter hardy; resistant to anthracnose; susceptible to cane blight.

Benefis. A floricane fruiting raspberry with a ripening season similar to Tulameen. Origin: Fruit Experiment Station, Brzezna, Poland, by Jan Danek. Beskid x Tulameen; selected in 1996; tested as 93022; introd. in 2003. Fruit: large size; elongated and compact; firm; red; shelf life similar to Glen Ample. Plant: produces numerous young primocanes without spines; strong laterals produce fruit half way down floricane.

Chinook. A primocane fruiting raspberry released as an early-season alternative to Autumn Bliss. Origin: USDA-ARS and Ore. St. Univ., Corvallis, Ore., by Chad E. Finn, Francis J. Lawrence, Brian M. Yorgey, and Bernadine C. Strik. ORUS 1823 x ORUS 1842, full sib to Summit; selected in 1976; tested as ORUS 534-10; introd. in 2004; not patented. Fruit: heavier than Heritage; very firm; rounded shape; drupelets consistent in size and shape giving uniform appearance; bright red, but darker than Heritage; flavor good but not as good as most Pacific Northwest 
floricane fruiting cultivars; ripening season earlier than Heritage and similar to Autumn Bliss and Summit; adapted to fresh market and shipping long distance. Plant: produces a very early spring crop on cut back floricanes; vigorous primocanes shorter with fewer nodes and not as sturdy as those of Heritage; requires support; productive; purple spines are infrequent; field tolerance to root rot (Phytophthora fragariae var. rubi); susceptible to Raspberry bushy dwarf virus (RBDV) but unknown how quickly it becomes infected.

Comtesse. A primocane fruiting raspberry with good vigor. Origin: Jacques Marionnet GFA, Soings en Sologne, France, by Jacques Marionnet. 63-1 x Sumo; cross made in 1987; introd. in UK in 2003. EU PVR applied for. Fruit: conical; shiny red and does not darken; good flavor; good presentation; early ripening season similar to Polana. Plant: good vigor; light green cane with short and fine spines.

Driscoll Cardinal. A very firm-fruited primocane raspberry. Origin: Driscoll Strawberry Associates, Inc., Watsonville, Calif., by Carlos D. Fear, Richard E. Harrison, Fred M. Cook, and Gavin Sills. M48.9 x Gloria; cross made in 1994; selected in 1995 in Carpenteria, Calif.; introd. in 2002. USPP 14,903. Fruit: medium size; red; uniform. Plant: very early ripening; fruits on primocanes.

Driscoll Carmelina. A good-flavored primocane fruiting raspberry. Origin: Driscoll Strawberry Associates, Inc., Watsonville, Calif., by Carlos D. Fear, Richard E. Harrison. Fred M. Cook, and Gavin Sills. P361.2 x N119.1; cross made in 1995; selected in 1997; introd. in 2002. USPP 14,761. Fruit: medium size; firm; red. Plant: vigorous; fruits on primocanes.

Driscoll Dulcita. A sweet-flavored primocane fruiting raspberry. Origin: Driscoll Strawberry Associates, Inc., Watsonville, Calif., by Carlos D. Fear, Richard E. Harrison, Fred M. Cook, and Gavin Sills. Gloria X N257.1; cross made in 1994; selected in 1995; introd. in 2002. USPP 14,904. Fruit: medium size; firm; red; uniform. Plant: fruits on primocanes.

Driscoll Francesca. A very good flavored primocane fruiting raspberry. Origin: Driscoll Strawberry Associates, Inc., Watsonville, Calif., by Carlos D. Fear, Richard E. Harrison, Fred M. Cook, and Gavin Sills. Tola X Isabel; cross made in 1996; selected in 1997 in Oxnard, Calif.; introd. in 2002. USPP 14,860. Fruit: large; firm; red. Plant: fruits on primocanes.

Driscoll Madonna. A primocane fruiting raspberry harvested and marketed with receptacle and stem. Origin: Driscoll Strawberry Associates, Inc., Watsonville, Calif., by Carlos D. Fear, Richard E. Harrison, Fred M. Cook, and Gavin Sills. R652.1 x R709.1; cross made in 1997; selected in 1998; introd. in 2002. USPP 14,781. Fruit: very large; glossy bright red; late ripening; does not separate easily from receptacle. Plant: fruits on primocanes; high yield; vigorous; tall.

Driscoll Maravilla. A primocane fruiting raspberry with a long post-harvest shelf life. Origin: Driscoll Strawberry Associates, Inc., Watsonville, Calif., by Carlos D. Fear, Richard E. Harrison, Fred M. Cook, and Gavin Sills. Q491.1 x Q480.3; cross made in 1996; selected in 1998; introd. in 2002. USSP 14,804. Fruit: very large; glossy, bright red. Plant: fruits on primocanes; high yield; vigorous.

Georgia. A very early ripening floricane fruiting raspberry adapted to the fresh market. Origin: Univ. of Maryland, by Harry J. Swartz. Glen Ample X PDW-4; selected in 2002; tested as TU-1; introd. in 2005. USPP pending. Fruit: smaller than Glen Ample; very firm; moderately light color; slightly pubescent; round with regular collar; strong raspberry aroma; higher soluble solids than Glen Ample; easy to harvest; high percentage of sound fruit; Plant: spineless; moderate production of primocanes; thin canes; moderate height; very productive; winter hardy in the United Kingdom and mid-Atlantic states; field resistance to root rot; susceptible to late leaf rust (Pucciniastrum americanum).

Helkal. A floricane fruiting raspberry with orange-yellow fruit and recommended for Estonia and Latvia. Origin: Polli Horticultural Centre, Estonia, by J. Parkseep. (Golden Queen x Spirina Belaya) x Novost Kuzmina; cross made in 1964; tested as 67-60-12; registered in 2004. Fruit: large; round to conical; orange-yellow; drupelets cohering firmly; excellent flavor. Plant: average yield; moderately strong growth of numerous erect light green primocanes thickly covered with spines; light brown floricanes; winter hardy. Resistant to cane blight; moderately susceptible to anthracnose.

Jaclyn. A very early ripening primocane fruiting raspberry for fresh market and pick-your-own. Origin: Univ. of Maryland, by Harry J. Swartz. Herb Stiles, Joseph A. Fiola, Brian Smith. OBC-fl x Caroline. OBC-1 has Rubus pileatus, $R$. stellarcticus, and $R$. parvifolius are in its background; cross made in 1996; selected in 1999; tested as QEG-F; introd. in 2004; USPP 15,647. Fruit: very conic with long receptacle; medium to large size; uniform; dark red; tends to soften in warm weather; excellent flavor; 1-2 d later than Polka in Europe and 2 weeks earlier than Caroline in Maryland Plant: numerous, robust canes; productive to 14 nodes in most areas but will fruit from lower buds after the first primocane crop is harvested; spiny; yield moderately high; will produce a good crop on remaining buds on overwintered canes; moderately winter hardy; leaves very susceptible to late season rust; does not show appreciable damage from leafhopper infestation.

Joan Irene. A high-yielding, primocane fruiting raspberry. Origin: Medway Fruits, Kent, UK by Derek Jennings. Joan J X selection of complex origin. Fruit: bright, medium color tends to darken if not picked regularly; good flavor; good skin strength which gives good shelf life; large size maintained late into season; ripens in southern England in late August and season continues until November. Plant: very vigorous; stout canes; spine free.

Laska. An early ripening floricane fruiting raspberry. Origin: The Fruit Experiment Station, Brzezna, Poland by Jan Danek. 80408 x 80182 (Malling Promise and Canby in derivations); selected in 1988; tested as 85361; introd. in 2003. EU PBR. Fruit: elongated shape; compact appearance; firm; compared to Tulameen larger or same size; light red; slightly pubescent; good flavor; good shelf life. Plant: average to high numbers of medium height, upright canes with short internodes; abundant medium length lateral shoots; fruits evenly distributed on laterals.

Malling Minerva. An early ripening floricane fruiting raspberry adapted to protected cropping and pick-your-own. Origin: East Malling Research Station, Kent, U.K., by Vicky Knight; an East Malling selection $\mathrm{x}$ a Scottish Crop Research Institute selection, has $R$. idaeus subsp. vulgatus, $R$. idaeus subsp. strigosus, $R$. occidentalis, $R$. crataegifolius, and $R$. phoenicolasius in its derivation; selected in 1987; tested as EM 6166/98; introd. in 2005. Fruit: size similar to Glen Moy and smaller than Glen Ample; good color; even, attractive shape; easy to pick; good flavor; shelf life better than Glen Moy. Plant: compact habit with spine-free easily managed canes; fruit well presented on medium length strong laterals with sparse foliage; early and even budbreak but not as prone to frost damage as Glen Moy; resistant to biotypes 1 through 4 of A. idaei, the European aphid vector of the raspberry mosaic virus complex; fairly resistant to cane diseases; moderately susceptible to root rot in glass house pot tests; has remained free of RBDV for 11 years.

Marwe. A high-yielding floricane fruiting raspberry suited to long-cane extended season production. Origin: Boomkwekerij, Netherlands by E.C. Meulblok. Selected in 1973; introd. in 1990. EU PVR grant no. 1769. Fruit: bright red; large; firm; ripens 1 week later than Glen Ample. Plant: vigorous; not susceptible to powdery mildew (Sphaerotheca macularis) or root rot. 
Polesie. A primocane fruiting raspberry, ripening 1 or $2 \mathrm{~d}$ earlier than Polka. Origin: The Fruit Experiment Station, Brzezna, Poland by Jan Danek. 86594 x 87432 (selections have Autumn Bliss in derivations); selected in 1995; tested as 93453; introd. in 2003. PBR. Fruit: large; slightly elongated shape; compact appearance; dark red; pubescent; good flavor. Plant: produces many young, straight canes of average height; fruits to half way down floricane.

PS-1049. A productive primocane fruiting raspberry with consistent primocane and floricane production in central California and in similar climates in Mexico. Origin: Plant Sciences Inc. and Berry R \& D, Inc., Watsonville. Calif. by Stephen M. Ackerman. PS-127 x Watson (USPP 7,067); selected in 1990; patented in 1997; USPP 10,142. Fruit: medium size, slightly larger than Heritage; glossy, medium red, firm with very good shelf life; darkens only slightly after 4 to 5 days storage; ripens in California on primocanes from mid-July through November and on floricanes from May through July. Plant: light green primocanes with waxy coating and moderately dense spines, larger at base than on upper cane; floricanes medium gray with medium waxy coat; slightly susceptible to yellow rust (Kuehneola uredinsis); powdery mildew and cane botrytis (Botrytis cinerea).

PS-1703. A productive, early-ripening primocane fruiting raspberry adapted to coastal central California, central Mexico, and similar climates elsewhere. Origin: Plant Sciences Inc. and Berry R\&D., Watsonville, Calif. by Stephen M. Ackerman. PSI-737 x PS-1049; patented in 2004; USPP 15,151 Fruit: conic; medium size, larger than PS 1049; glossy medium red with even coloring; firm with good shelf life; ripens in California on primocanes from July through November followed on floricanes in May through July. Plant: primocanes medium in length; medium green with red overcast; medium to strong waxy coat and moderately dense short spines; moderately tolerant to powdery mildew and moderately resistant to yellow rust.

Saanich. A high-yielding floricane fruiting raspberry with excellent fruit qualities suited to both the fresh market and processing markets. Origin: Agriculture and Agri-Food Canada, Pacific Agriculture Research Centre, Agassiz, B.C., Canada, by Chaim Kempler and Hugh A. Daubeny. BC 82-5-161 (Algonquin x Chilliwack) x BC 80-28-50 (Nootka x Glen Prosen); cross made in 1989 by HAD; selected in 1992 by HAD; tested as BC 89-34-41; introd. in 2005. Fruit: medium size; medium glossy red; firm with even drupelets; pleasant sweet flavor comparable to Tulameen; easily removed from receptacle; midseason ripening. Plant: flowers a few days earlier than Meeker and same time as Tulameen; very even budbreak; productive; canes gray to light brown and darker than Meeker; top of cane is spine free and lower 40-cm portion has a few light grey spines; short laterals that bend easily without breaking; resistant to the common strain of the North American aphid vector of raspberry mosaic virus; susceptible to RBDV but slow to become infected in the field; reaction to root rot unknown; similar susceptibility to cane spot and cane botrytis as Meeker and Tulameen; lower susceptibility to spur blight (Didymella applanata) than Meeker, Tulameen and Willamette, each of which is susceptible.

Tomo. A floricane fruiting raspberry that produces fruit especially good for freezing and recommended for Estonia and Latvia. Origin: Polli Horticultural Centre, Estonia by J. Parkseep. Superlative x Novost Kuzmina; cross made in 1964; registered in 2004. Fruit: medium size; round or oblate; dark red; drupelets cohere firmly. Plant: average yield; moderately strong growing with medium to numerous erect light green primocanes with weak spines; light brown with grey-tinge light brown fruiting-canes; moderately winter hardy; resistant to cane blight; moderately susceptible to anthracnose.

Valentina. An early ripening, high-yielding floricane raspberry with apricot-colored fruit. Origin: East Malling Research Station, Kent UK by Vicky Knight. EM 6225/11 x EM 5588/81; cross made in 1990; selected in 1994; tested as EM 6432/71; introd. in 2005. Fruit: medium to large; blunt conical; bright, pink-apricot color; easily picked; fair to good flavor; soft skin; color goes uneven after $72 \mathrm{~h}$ at ambient temperature and high humidity very attractive on plant. Plant: new canes are tall and upright with few spines; canes show nil or only slight cane botrytis, spur blight, and cane spot; early flowering but little evidence of frost damage; crops well towards base of cane; high yielding; well presented fruit; resistant to biotypes 1 through 4 of Aphis idaei, the European aphid vector of the raspberry mosaic virus complex; appears to have field resistance to RBDV; resistant to root rot in glasshouse pot tests.

\section{STRAWBERRY}

Kim S. Lewers and John L. Maas

USDA-ARS Beltsville Agricultural Research Center

Fruit Laboratory, Beltsville, Md.

Alba (cv. NF311). A short-day cultivar adapted to the central-northern region of Italy and suitable for tunnel and open-field culture. Origin: New Fruits, s.a.s., Cesena, Italy, by D. Musacchi, G. Raggi, D. Bernadini, and E. Marchetti. Unreported parentage; cross made in 1995; discovered in Cesena, Italy, in 1997; tested as NF 311; patented in 2006. EU PVR grant no. 16744. Fruit: large; quite uniform; long conical; bright red; good flavor; produces fruit in the early season. Plant: short-day type; quite vigorous; medium erect habit; high yielding.

Albion. A day-neutral cultivar similar to Diamante but with better fruit quality. Origin: Univ. of California, Davis, Calif., by Douglas V. Shaw and Kirk D. Larson. Diamante x Cal 94.16-1; cross made in 1997; selected 1998; designated as Cal 97.117-3 and then tested as CN220; patented 2006. USPP 16,228. Fruit: large (33 g), similar to Diamante; less firm but darker colored than Diamante; long conic; excellent flavor; very sweet; production pattern similar to Diamante but slightly earlier. Plant: day-neutral type with weak to moderate expression of day-neutral character; more erect and open than Diamante; comparable yield to Diamante; moderately resistant to common leaf spot and crown rot; quite resistant to verticillium wilt and phytophthora crown rot; tolerant to two-spotted spider mites.

Asia. A short-day cultivar adapted to autumn production in central northern region of Italy, and suitable for tunnel and open-field culture. Origin: New Fruits s.a.s., Cesena, Italy, by G. Raggi, A. Siboni, D. Bernadini, and E. Marchetti. Unreported parentage; discovered in 1998; tested as NF 421. EU PVR Pending. Fruit: large; quite uniform; very nice longconical shape; bright red; good flavor; produces fruit in the mid-early season. Plant: short-day type; vigorous; erect habit; high yielding.

BG269. A high-quality short-day cultivar that produces a large, vigorous plant with few runners per plant, is high yielding, has large berries with excellent flavor, and is particularly well adapted to coastal, southern California. Origin: Berry Genetics, Inc., Freedom, Calif. by Steven D. Nelson, Michael D. Nelson, and Leo W. Stoeckle. PS-592 x Carlsbad; selected in 1996; patented in 2002. USPP 12,628. Registered in Europe and other countries as Commitment. Fruit: characteristically rounded to conical; very attractive; glossy; very large (30.4 g), larger than Camarosa; excellent flavor and juiciness; moderate firmness, less firm than Camarosa; high yield; surface is deep red with medium red flesh; achenes are even with the fruit surface; later ripening than Camarosa. Plant: upright and vigorous; large with multiple crowns producing very few runners; inflorescence is long extending the flowers and fruit above the plant; high yields throughout the season, typically mid-January into June; performs best with a minimal nitrogen fertilizer program; moderately tolerant to Botrytis cinerea (botrytis fruit rot) and Sphaerotheca macularis f. sp. fragariae (powdery mildew); susceptible to Xanthomonas fragariae (angular leaf spot).

BG-625. A high-quality, short-day cultivar, primarily adapted to coastal, southern California, characterized by its large, glossy berry, excellent 
flavor and strong plant. Origin: Berry Genetics, Inc., Freedom, Calif., by Steven D. Nelson, Michael D. Nelson, and Leo W. Stoeckle. Anaheim x PS-592; selected in 1997; patented in 2002. USPP 13,255. Registered in Europe and other countries as Patience. Fruit: orange-red; conical to cordiform; very attractive; glossy; large with excellent flavor and juiciness; medium firmness; orange-red with light red colored flesh; season from January to June, lightly later than Camarosa. Plant: shortday type, with an upright habit; larger and more vigorous than Camarosa with similar yields; performs best on a low nitrogen fertilizer program; moderately susceptible to botrytis fruit rot and powdery mildew and somewhat resistant to angular leaf spot.

BG-633. A short-day cultivar characterized by extremely firm, cylindrical shaped fruit, primarily adapted to coastal, southern California and similar climates in numerous other countries. Origin: Berry Genetics, Inc., Freedom, Calif., by Steven D. Nelson, Michael D. Nelson, and Leo W. Stoeckle. Camarosa x PS-1269; selected in 1997; patented in 2002. USPP 13,320. Registered in Europe and numerous other countries as Honor. Fruit: characteristically cylindrical, large with good flavor, firm; production from January through June; red with medium red colored flesh; redder, larger and slightly less yield than Camarosa; achenes are level with the surface. Plant: short-day type, vigorous with an upright habit; flowers typically level to above the foliage; moderately tolerant to botrytis fruit rot and angular leaf spot.

Carmela. A very early producing short-day cultivar adapted for tunnel production in the Huelva region of Spain. Origin: Plantas de Navarra S.A., Valtierra, Spain, by I.A. Rubio, Navarra, Spain. 86-032 (open pollinated selection) X 9261; patented 2005. USPP 15,783. EU Rights pending. Fruit: orange-red; conical; very firm; medium size; only slight difference in shapes between primary and secondary fruits; medium glossiness; medium band without achenes; achenes inserted below fruit surface; harvest from late January through mid-May with maximum production in mid-April. Plant: globose habit with medium dense canopy, and medium vigor; abundant production.

Carmine. A short-day cultivar developed for west-central Florida to be an alternative to Sweet Charlie and producing high early-season yields of firm, attractive fruit. Origin: Univ. of Florida, by Craig K. Chandler, Daniel E. Legard, Timothy E. Crocker, and Charles A. Sims. Rosa Linda x FL 93-53; cross made in 1995; tested as FL 95-256; released in 2004. USPP applied for. Fruit: mostly short to medium conic to wedge-shaped; deep red color, darker than Sweet Charlie and similar to Camarosa and Strawberry Festival; glossy; firm and juicy; not as flavorful as Camarosa, Sweet Charlie, or Strawberry Festival; produced from December through March. Plant: compact habit with long, stiff pedicels that make fruit easy to harvest; yields during December can be twice that of Sweet Charlie; moderately resistant to botrytis fruit rot and Colletotrichum acutatum (anthracnose fruit rot).

Charlotte. A high-quality everbearing strawberry cultivar. Origin: Centre Interrégional de Recherche et d'Expérimentation de la Fraise, Bergerac, France, by Philippe Roudeillac, Sophie Ponson, and Philippe Chartier. Mara des bois x Cal 19; selected in 1995; registered in 2004. EU PVR grant no. 13354. CTPS No. 1013116. Fruit: large, 14-16 g; ovoid to short wedge; blood red with a good coloring potential in autumn; medium glossiness; achenes are sometimes slightly raised above surface; high soluble solids level and low titratable acidity; excellent fresh flavor; very good consumer acceptance; strong skin; good shelf life; regular flowering with continuous production; high percentage of marketable fruits ( $75 \%$ to $80 \%$ ); consistent size over harvest season; quick picking speed. Plant: day-neutral; medium vigor; flat and low growth habit; prefers low levels of fertilization; good tolerance to powdery mildew on the plant, somewhat less tolerant on fruits, and to Phytophthora cactorum (phytophthora crown rot).

Chelsea Pensioner. A high-yielding, late cultivar being marketed primarily for home gardeners. Origin: Medway Fruits, Maidstone,
UK, by Derek L. Jennings. Parents of complex origin derived from British and Italian germplasm; cross made in 1998. Fruit: very deep red; firm; slightly prominent achenes; exceptionally good flavor; many supermarkets do not favor its deep color, so it is not being marketed for commercial use.

Chiflón® (cv. Plarionfre). A short-day cultivar with inflorescences that appear above the foliage, producing abundant conical red fruit, and adapted to the Huelva region of Spain. Origin: Planasa Plantas de Navarra, S.A., Tudela, Spain, by J.M.A. Lopez, Navarra, Spain. 9244 X 86-032; evaluated as 96.09.812 in Huelva, Spain; patented 2003. EU PVR 10429. Registered in some countries as Chiflón. Fruit: large; red; conical; glossy; medium red and firm flesh; narrow band without achenes; achenes inserted level with the fruit surface; fruit harvest from January through May. Plant: flat, globose habit; open with medium vigor; low chilling requirement.

Dange. A late-midseason short-day cultivar adapted to the growing conditions of Lithuania and adjacent countries and having large attractive fruit, and stable, high yields every year. Origin: Lithuanian Institute of Horticulture, Babtai, Lithuania, by R. Rugienius, A. Sasnauskas, and T. Shikshnianas. Venta X Red Gauntlet; selection made in 1992; tested as 80-6-3; released in 2002. Fruit: attractive; bright red; glossy; conic to cordate in shape; large; firmer and have longer shelf life than other cultivars grown in Lithuania; moderate; harvest period a few days later than Elsanta. Plant: vigorous; dark green leaves on long petioles; winter hardy; abundant runners; productivity equal to Venta; resistant to Mycosphaerella fragariae (leaf spot), Diplocarpon earliana (leaf scorch), verticillium wilt, and red stele.

Dora. A midseason short-day cultivar adapted to northern Italy. Origin: Verona, Italy, by W. Faedi and G.Baruzzi (CRA-Istituto Sperimentale per laFrutticoltura-Forlì Section), G. Baroni and L. Ballini(Verona Province) and F. Zenti (Strawberry Growers Association Aposcaligera-Verona). 91.143.5 x 90.608.1; cross made in 1996 in Cesena; selected in Verona in 1998; tested as VR 96.58.2; EU PVR pending. Fruit: large; conical; very firm; tough skin; bright red; high sugar content; pleasant aroma. Plant: vigorous; well adapted to Verona fall culture; medium yield in the fall, high in the spring; it needs an early planting date for high yield; tolerant to anthracnose crown rot, Alternaria alternata $\mathrm{f}$. sp. fragariae (alternaria black leaf spot), powdery mildew, and leaf spot; susceptible to angular leaf spot; it needs fumigated soil for good performance.

Driscoll Agoura. A partially everbearing cultivar that produces large, dark-red, early season fruit on weakly vigorous plants, and is adapted to the Ventura County region of California. Origin: Driscoll Strawberry Associates, Watsonville, Calif., by Amado Q. Amorao, Arnoldo Solis, Jr., and Michael Ferguson; 61C117 x 19A268, selected in 1998; patented 2005. USPP 15,731. Fruit: size similar to fruit of El Capitan and San Miguel; firm; very glossy; dark red with orange red flesh; wedge to cordate shape, with marked differences between primary and secondary fruits; very narrow band without achenes, and achenes insertion level with surface; surface very uneven; fruit harvest from late-January through mid-June. Plant: moderate crown producer; flat globose habit with open canopy; weak vigor; susceptible to Lygus hesperus (western tarnished plant bug) and verticillium wilt; moderately susceptible to botrytis fruit rot and angular leaf spot; and moderately resistant to Tetranychus urticae (two-spotted spider mite), powdery mildew, high soil $\mathrm{pH}$, and high soil salt levels.

Driscoll Camarillo. A fully everbearing cultivar with long fruiting trusses, globose plant habit, even fruit coloration, and an absent to small hollow center of fruit; adapted to the Ventura County region of California. Origin: Driscoll Strawberry Associates, Inc. Watsonville, Calif., by Amado Q. Amorao, Arnoldo Solis, Jr., and Michael Ferguson. Baeza X 33X57; selected in Ventura County in 1997; patented 2004. USPP 14,771. Fruit: cordate; red with orange-red flesh; glossy; achenes inserted below surface; firm flesh with no or small hollow; 
medium sweetness, acidity, and texture; calyx insertion in a basin and spreading; harvest period from late September through late December. Plant: globose; open habit; medium vigor; fruiting trusses prostrate at harvest; moderately resistant to $\mathrm{pH}$ induced stress, high soil salinity, Strawberry mottle virus, and angular leaf spot; moderately susceptible to two-spotted spider mite; and susceptible to botrytis fruit rot, powdery mildew, and verticillium wilt.

Driscoll Cambria. A partially everbearing cultivar with large, firm, fine textured fruit, and adapted to northern California. Origin: Driscoll Strawberry Associates, Inc., Watsonville, Calif. by Amado Q. Amorao, Bruce P. Mowrey, Michael Ferguson, Larry T. Kodama, and JoAnne Coss. 61C117 x 126B46; selected in 1998 in Ventura County, Calif.; patented 2005. USPP 15,596. Fruit: large; cordate-shaped with a narrow band without achenes; sweet with fine texture; firm; superior shipability; achenes inserted level with the fruit surface; producing from early April through early November. Plant: partially everbearing; globose habit; dense; strongly vigorous; moderately resistant to stress from high soil $\mathrm{pH}$ and soil salt levels; moderately susceptible to two-spotted spider mite, angular leaf spot; susceptible to western tarnished plant bug, botrytis fruit rot, and powdery mildew.

Driscoll Coronation. A fully everbearing cultivar with large, glossy, red fruit having whitish flesh, and adapted to the central coastal area of California. Origin: Driscoll Strawberry Associates, Inc., Watsonville, Calif., by Thomas M. Sjulin, Joseph T. DeRuse, and Bruce D. Mowrey. Marathon x 38A237; selected in 1999 in Kent, England; patented 2004. USPP 15,308. Fruit: cordate; very glossy; red exterior and whitish flesh; medium firmness; small to medium central hollow; very sweet; weakly acidic; fine textured; achenes inserted level with skin surface and the band without achenes is very narrow. Plant: flat; globose; weak to medium vigor; inflorescences level with foliage; fruit trusses prostrate at harvest; moderately resistant to stress from high soil $\mathrm{pH}$; moderately resistant to moderately susceptible to botrytis fruit rot; moderately susceptible to high soil salinity, two-spotted spider mite, powdery mildew, and verticillium wilt; susceptible to western tarnished plant bug.

Driscoll Jubilee. A productive everbearing cultivar with small spreading plant, conic shaped fruit, and adapted to central coastal California. Origin: Driscoll Strawberry Associates, Inc., Watsonville, Calif., by Thomas M. Sjulin, JosephT. DeRuse, and JoAnne Coss. 50C130 x 19A331; selected in Kent, England in 1999; patented in 2004. USPP 15,435. Fruit: internal color white interspersed with red in a striped manner, compared to orange-red in Driscoll Camarillo; fruit size and external color similar to Driscoll Camarillo and Driscoll Coronation; medium to firm flesh; medium to strong sweetness, acidity, and flesh texture. Plant: flat globose; open to medium density; weak to medium vigor, similar to Driscoll Coronation; inflorescence beneath foliage; fruiting trusses semi-erect; susceptible to high soil salinity, western tarnished plant bug, powdery mildew; moderately resistant to high $\mathrm{pH}$, two-spotted spider mite, botrytis fruit rot, and verticillium wilt.

Driscoll Lanai. A partially everbearing cultivar with conical to ovoid orange-red fruit with medium flesh firmness, and adapted to central coastal California. Origin: Driscoll Strawberry Associates, Inc, Watsonville, Calif., by Bruce D. Mowrey, Larry T. Kodama, and JoAnne Coss. 62A313 x San Juan; selected in Monterey, California, in 1999; patented 2004. USPP 15,145. Fruit: glossy; fine textured; orange-red exterior and interior; conical to ovoid; slight difference in shape between primary and secondary fruit; medium firmness; narrow to medium band without achenes; achenes inserted level with skin surface; hollow center medium in size; harvest period late March through early November. Plant: partially everbearing; flat habit; open canopy; medium vigor; inflorescences level with or above foliage; fruit trusses prostrate at harvest; high number of crowns produced; moderately resistant to verticillium wilt and Strawberry mottle virus; moderately susceptible to bacterial angular leaf spot; susceptible to two-spotted spider mite, western tarnished plant bug, botrytis fruit rot, and powdery mildew.
Driscoll Malibu. A partially everbearing cultivar that produces darkred fruit having superior shelf-life, and is adapted to the environmental growing conditions of the western central region of Florida. Origin: Driscoll Strawberry Associates, Watsonville, Calif., by Kristie L. Gilford, Bruce D. Mowrey, and JoAnne Cross. Driscoll Marathon x Driscoll Sonora; selected in Hillsborough County, Fla. in 1998; patented 2005. USPP PP16,070. Fruit: Conical; very glossy; small central hollow; very narrow band without achenes; medium sweetness and acidity; soft to medium firmness; darker red and with a superior shelf-life compared to Driscoll Marathon and brighter red than Driscoll Sonora; harvest from November through late March. Plant: globose habit; weak to medium vigor; medium canopy density; inflorescences level to above foliage; flowering very early; partially everbearing; moderately susceptible to angular leaf spot and powdery mildew; susceptible to two-spotted spider mite, western tarnished plant bug, botrytis fruit rot, and Strawberry mottle virus; very susceptible to verticillium wilt.

Driscoll Marin. A partially everbearing cultivar with intensely red fruit, superior fruit firmness, and superior late season production, and is adapted to the climate of northern California. Origin: Driscoll Strawberry Associates, Watsonville, Calif., by Bruce D. Mowrey, Larry T. Kodama, and JoAnne Coss. 67C253 x Lido; selected in Monterey, Calif. in 1998; patented in 2004. USPP 15,375. Fruit: conical to nearly cylindrical; dark red with firm, orange-red flesh; glossy; medium-sized hollow center; medium sweetness and acidity; fine to medium texture; very narrow to narrow band without achenes; achene insertion level with the skin surface; harvest period from late April through early November. Plant: partially everbearing; flat; open; weak vigor; moderately resistant to stress due to high soil $\mathrm{pH}$ and soil salinity, and Strawberry mottle virus; moderately susceptible to powdery mildew; susceptible to two-spotted spider mite, western tarnished plant bug, botrytis fruit rot, verticillium wilt, and angular leaf spot.

Driscoll Osceola. A partially everbearing cultivar that produces long fruiting trusses, large dark red fruit, large yields, and is adapted to Hillsborough County region of Florida. Origin: Driscoll Strawberry Associates, Watsonville, Calif., by Kristie L. Gilford, Bruce D. Mowrey, and JoAnne Cross. Marathon x Sonora; selected in Monterey, Calif. in 1999; patented 2005. USPP 15,752. Fruit: larger and with superior shelf-life compared to Marathon; cordate-shaped; soft to medium firm flesh; strongly glossy; dark red externally and orange-red internally; very narrow band without achenes; achenes inserted below the fruit surface; harvests from late November through late March. Plant: flat globose habit with open to medium canopy; medium vigor; yields greater than those of Biscayne and somewhat less than those of Madeira; susceptible to two-spotted spider mite, western tarnished plant bug, botrytis fruit rot, verticillium wilt, and Strawberry mottle virus; moderately susceptible to powdery mildew and angular leaf spot.

Eva. A midseason short-day cultivar adapted to northern Italy (Verona area). Origin: Verona, Italy, by W. Faedi and G. Baruzzi (CRA-Istituto Sperimentale per la Frutticoltura - Forlì Section), G. Baroni and L. Ballini (Verona Province) and F. Zenti (Strawberry Growers Association Aposcaligera - Verona). Darselect x 89.384.20 (Marmolada X Irvine); cross made in 1997; selected in Verona in 1999; tested as VR 97.64.5; released in 2004; EU PVR pending. Fruit: large; conical; very firm; tough skin; bright orange-red color; good flavor. Plant: short day type characterized by a good second blooming in autumn and spring before three to four weeks of the main blooming period; medium vigorous; very well adapted to Verona fall culture; tolerant to anthracnose crown rot, powdery mildew, leaf spot and to soilborne pathogens; susceptible to alternaria black leaf spot and angular leaf spot.

Franor. An ornamental strawberry cultivar characterized by large, single, bright red-purple flowers that bloom from mid-May through early November in the United Kingdom. Origin: Blooms of Bressingham, Norfolk, U.K., by W. Bittner, Willstattland, Denmark. A spontaneous mutation occurring on Frel and discovered in Hamm, Federal Republic 
of Germany; patented 2001. USPP 12,169. Plant: forms bushy clumps that spread by runners, forming a carpet of foliage; Flower color bright reddish purple compared with the much lighter, pinkish red-purple flower color of Frel; Fruit: Only a small amount of small fruit produced, being grown primarily for its flowering properties.

Gemma (cv. NF245). A short-day cultivar adapted to the centralnorthern region of Italy, and suitable for open-field culture. Origin: New Fruits, s.a.s, Cesena, Italy, by G. Raggi, A. Siboni, D. Bernadini, and E. Marchetti. Discovered in 1997; tested as NF 245; EU PVR pending, Fruit: quite large; firm; very nice uniform conical shape; bright red; good flavor and shelf life; midseason. Plant: short-day type; sufficient vigor; erect habit; average yields.

Marina. A short-day cultivar that produces early high yields of excellent flavored fruit and is adapted to the southwestern coast of Spain and other regions of similar climate. Origin: A result of public and private institutions in Spain to develop new cultivars adapted to Huelva and other regions, by J.M. López-Aranda, C. Soria, J.F. Sanchez-Sevilla, and J. Gálvez (Junta de Andalucia, Málaga), J.J. Medina (Junta de Andalucia, Huelva), A. Arjona (Viveros California, S.L.), and J.L. Marsal and R. Bartual (Instituto Valenciano Investigaciones Agrarias - IVIA, Valencia, Spain. Cartuno x Camarosa; selected in 1998; tested as RB-975; released 2002. EU PVR applied for. Fruit: moderately firm; nearly cylindrical, slightly longer than broad; medium size but consistent throughout most of the fruiting season; dark red and glossy; medium red flesh with a conspicuous cavity; flavor is excellent and the aroma is pleasing; early ripening season Plant: vigorous; compact with a globose habit and tendency to produce numerous runners; yields similar to Camarosa; foliage is moderately resistant to powdery mildew, but the fruit may be susceptible.

Medina. A productive, early ripening, short-day cultivar that has high yields of first-quality fruit, and is adapted to the Huelva region of Spain. Origin: A result of public and private institutions in Spain to develop new cultivars adapted to Huelva and other regions by J.M. López-Aranda, C. Soria, J.F. Sanchez-Sevilla, and J. Gálvez (Junta de Andalucia, Málaga), J.J. Medina (Junta de Andalucia, Huelva), A. Arjona (Viveros California, S.L.), and J.L. Marsal and R. Bartual (Instituto Valenciano Investigaciones Agrarias - IVIA, Valencia, Spain. Z-45 x Parker selected in 1994; tested as 4-129. released 2002; EU PVR applied for. Fruit: moderately firm; mostly large; conical-bi-conical; red and slightly glossy; conspicuous internal cavity; harvest begin in early January. Plant: vigorous; compact with a globose growth habit; tendency to produce numerous runners; low susceptibility to powdery mildew and two-spotted spider mite; less susceptible to verticillium wilt and phytophthora crown rot than is Camarosa.

NB-1. A winter-planted, short-day cultivar adapted to the growing conditions and climate of the southern coast of California. Origin: J. Sterrett, Murrieta, Calif. Pajaro open pollinated; selected in 1998 in Vista, Calif.; patented 2003. USPP 13,986. Fruit: large; conical; smooth and uniformly-shaped; flesh texture described as "peach-like"; early harvest season; and has good cold-storage qualities. Plant: vigorous with many crowns; erect, dense and globose habit; requires minimal chilling; relatively resistant to powdery mildew.

NF 205. See Roxana.

NF 245. See Gemma.

NF 302. See New Ruby

NF 311. See Alba.

New Ruby (cv. NF302). A late ripening, short-day cultivar adapted to the central-northern region of Italy, and suitable for open-field and tunnel production. Origin: New Fruits, s.a.s, Cesena, Italy. Selected in 1999; tested as NF 302. Fruit: large, 29 g; uniform conic; bright red; very good flavor and aroma; late, 2 d later than Marmolada. Plant: short-day type; medium vigor; compact habit; average yields.

Nicola. Ripens five days earlier than Elsanta and not as early as Christine, but, unlike many early varieties, it is capable of very high yields that usually exceed those of later ones. Origin: Redeva Ltd., UK, by Derek L. Jennings of Maidstone, U.K. Symphony $x$ parent of complex origin; cross made in 1996. Fruit: excellent shelf-life; medium red; bright; good flavor; occasionally a small area devoid of achenes around the calyx that becomes red as the fruit ripeness. Plant: highly resistant to red stele but susceptible to powdery mildew.

Plahuelfre. A productive short-day cultivar with large, firm red fruit, and adapted to the Huelva region of Spain. Origin: Planasa-Plantas de Navarra, S.A., Tudela, Spain, by J.M.A. Lopez. 244 x 86-032; selected in Cartaya (Huelva) Spain; tested as 96.09.014; patented 2004. USPP 15,153. Fruit: slightly larger and firmer than Cartuno; conical; redder but less glossy than Cartuno; depressed achenes; strongly adherent calyx that is reflexed; good flavor; more acidic and less sweet than Cartuno; midseason but earlier than Cartuno and Camarosa. Plant: short-day; very vigorous; globose habit; inflorescences produced level with the foliage; productivity similar to Cartuno but less than Camarosa.

\section{Plarionfre. See Chiflón®.}

PS-592. A high-quality short-day cultivar characterized by its excellent flavor, strong plant with high yields that is particularly well adapted to coastal, central California. Origin: Plant Sciences Inc. and Berry R. \& D., Inc., Watsonville, Calif., by Stephen M. Ackerman, Steven D. Nelson, Michael D. Nelson, Peter Salm, and Daniel T. Schmida. PS-61 x PS-143; selected in 1991; patented in 1997. USPP 9,903. Registered in Europe and other countries as Endurance. Fruit: characteristically conical; very attractive; glossy; large; excellent flavor and juiciness; moderate firmness; excellent holding quality; surface is medium red with light colored flesh; surface is smooth and achenes do not protrude. Plant: short-day type, strong and vigorous with an upright habit; performs best on a low nitrogen fertilizer program; moderately susceptible to angular leaf spot; slightly susceptible to botrytis fruit rot.

PS-2880. A strong, versatile day-neutral cultivar characterized by medium sized fruit, vigorous plant with many crowns per plant that is particularly well adapted to fall production in southern and coastal California and summer to fall production in diverse international climates as well as tunnels. Origin: Plant Sciences Inc. and Berry R. \& D., Inc., Watsonville, Calif., by Stephen M. Ackerman, Michael D. Nelson, and Steven D. Nelson. PS-592 x PS-1391; selected 1994; patented 2005. USPP 15,597. Registered in Europe and other countries as Promise. Fruit: conic to wedge shaped; medium size; good flavor; smaller, firmer, redder skin and flesh than that of PS-592; achenes extruded more than those of PS592. Plant: strong and vigorous; smaller with more crowns/plant than PS-592; moderately susceptible to angular leaf spot and botrytis fruit rot; susceptible to powdery mildew.

Record. A late season, short-day cultivar adapted to the northern Italy. Origin: Italian National Project "Frutticoltura", Cesena, Italy, by W. Faedi and G. Baruzzi (CRA-Istituto Sperimentale per la FrutticolturaForlì Section), M. Baudino and R. Giordano (Consorzio di Ricerca Sperimentazione e Divulgazione per l'Ortofrutticoltura Piemontese -Cuneo), P. Lucchi (Centro Ricerche Produzioni Vegetali-Cesena). Idea x Marmolada; cross made in 1992; selected in Cesena in 1994; tested as 92.340.3; released in 2005; EU PVR pending. Fruit: large, symmetric conic shape; medium-firm skin, very bright orange-red; medium firm flesh; good organoleptic characteristics; high ascorbic acid content. Plant: vigorous; good yield; well adapted to organic culture, un-fumigated soils, and poor soils; tolerant to anthracnose crown rot and powdery mildew; susceptible to leaf scorch and angular leaf spot. 
Roxana (cv. NF205). A short-day cultivar adapted to the central-northern region of Italy and suitable for tunnel and open-field culture, with large autumn harvests. Origin: New Fruits, s.a.s., Cesena, Italy, by D. Musacchi, D. Bernadini, and E. Marchetti. Surprise de Halles X Senga Sengana; selected in Cesena, Italy in 1995; tested as NF 205; patented in 2005. EU PVR 14557. Fruit: very large; quite uniform; long conic; bright red; sufficient flavor; produces fruit in the early season. Plant: short-day type; quite vigorous; medium erect habit; very high yielding; shows good tolerance to most common diseases.

Saulene. An early-season short-day cultivar with excellent fruit quality, and high and concentrated yields, and adapted to Lithuania and adjacent countries. Origin: Lithuanian Institute of Horticulture, Babtai, Lithuania, by R. Rugienius, A. Sasnauskas, and T. Shikshnianas. Shuksan x Senga Sengana; cross made in 1992; tested as 80-4-1; released in 2002. Fruit: conical-ovoid; strong red color; medium size; excellent flavor; fruit firmness is greater and shelf life longer than fruit of Venta, the standard Lithuanian cultivar; early season fruit production is five to seven days earlier and more concentrated in the first week of harvest than Venta. Plant: vigorous but subject to winter cold injury; yields greater than yields of Venta.

Shimei 3. A good-quality, high-yielding, and early to midseason ripening cultivar suitable for areas in northern and northeastern China. Origin: Shijiazhuang Pomology Institute of Hebei, Academy of Agricultural and Forestry Sciences, Shijiazhuang, China. 183-2 x Allstar; cross made in 1990. Fruit: large; good flavor; high quality. Plant: vigorous; high yields.

Shimei 4. An early-ripening cultivar well adapted to China. Origin: Shijiazhuang Pomology Institute of Hebei, Academy of Agricultural and Forestry Sciences, Shijiazhuang, China. Hokowase x Shimei 1. Fruit: shape is coniform; large primary fruit, $36.7 \mathrm{~g}$; well-proportioned and symmetric; good storage quality; flesh is fine-textured; fragrant. Plant: high yield; low chilling requirement.

Sugar Lia. An early season, short-day cultivar adapted to the Northern Italy. Origin Italian National Project "Frutticoltura", Cesena, Italy, by W. Faedi and G. Baruzzi (CRA-Istituto Sperimentale per la Frutticoltura - Forlì Section), M. Baudino and R. Giordano (Consorzio di Ricerca Sperimentazione e Divulgazione per l'Ortofrutticoltura Piemontese - Cuneo), P. Lucchi (Centro Ricerche Produzioni Vegetali - Cesena). 91.143.5 (86.288.1 x Cortina) x Miss; cross made in 1996; selected in Cesena in 1998; tested as 96.62.10; released in 2005. Fruit: mediumlarge; symmetric conic shape; very firm skin; bright red; firm flesh; high sugar content; faintly aromatic; medium-high ascorbic acid content. Plant: medium vigor; productive but needs an early planting date for high yield on fumigated fertile soils; medium susceptible to alternaria black leaf spot and powdery mildew; susceptible to anthracnose crown rot, angular leaf spot and Phytophthora cactorum (leather rot).

Wendy. A productive, early season, short-day cultivar adapted to mattedrow culture in Eastern Canada. Origin: Agriculture and Agri-Food Canada, Atlantic Food and Horticulture Research Centre, Kentville, Nova Scotia by Andrew R. Jamieson. K96-5 x Evangeline; cross made in 1997; selected in 1998; tested as K98-6, Canadian PBR applied for in 2005. Fruit: larger than Evangeline, primary fruit wedge-shaped, others conic; achenes are level with the fruit surface; firmness and color similar to Evangeline; excellent fresh flavor; ripens with Evangeline and Annapolis. Plant: short-day; vigorous; runners well; productive in matted rows; moderately resistant to powdery mildew; susceptible to verticillium wilt.

\section{TROPICAL FRUIT-ACEROLA}

Robert J. Knight, Jr.

Univ. of Florida, Tropical Research and

Extension Center, Homestead

Apodi (BRS 235). A large fruited acerola. Origin: Ceará, Brazil. Fruit: large (11.8 g, 53.99\% pulp); medium-firm; vitamin C content 1260.9 $\mathrm{mg} / 100 \mathrm{~g}$ pulp; anthocyanins $12.26 \mathrm{mg} / 100 \mathrm{~g} ; 6.4 \%$ SS. Plant: compact and easy to harvest; highly productive.

Cereja (BRS 236). An acerola with high vitamin $C$ content. Origin: Ceará, Brazil. Fruit: small (7.56 g, 51.9\% pulp); firm; vitamin C content $1854.9 \mathrm{mg} / 100 \mathrm{~g}$; anthocyanins $9.3 \mathrm{mg} / 100 \mathrm{~g} ; 6.2 \%$ SS. Plant: compact; easy to harvest; productive.

Frutacor (BRS 238). An acerola whose fruit have a high vitamin C content. Origin: Ceará, Brazil. Fruit: small (6.6 g); firm; vitamin C content $1656.1 \mathrm{mg} / 100 \mathrm{~g}$; anthocyanins $4.57 \mathrm{mg} / 100 \mathrm{~g}$; 8.3\% SS. Plant: compact; easy to harvest; productive.

Roxinha (BRS 237). An acerola that requires less pruning produces fruit with purple pulp. Origin: Ceará, Brazil. Fruit: medium-large (10.8 g, 41.93\% pulp); red-purple colored pulp; firm; vitamin C content 1193.9 mg/100 g; anthocyanins $12.64 \mathrm{mg} / 100 \mathrm{~g} ; 8.3 \%$ SS. Plant: good shape; demanding little pruning; moderately productive.

Sertaneja. A productive acerola with high vitamin $\mathrm{C}$ content. Origin: Ceará, Brazil. Fruit: small (7.2 g, 53.45\% pulp); firm; vitamin C content $1421.5 \mathrm{mg} / 100 \mathrm{~g}$; anthocyanins $11.35 \mathrm{mg} / 100 \mathrm{~g} ; 6.4 \%$ SS. Plant: compact; easy to harvest; moderately productive.

\section{TROPICAL FRUIT-AVOCADO}

Robert J. Knight, Jr.

Univ. of Florida, Tropical Research and

Extension Center, Homestead

Alpha Krome. A late maturing avocado. Origin: Homestead, Florida by William H. Krome, Phoebe von P. Krome, and Neal P. Brooks. Unknown parentage; identified in 2000 and estimated to be 25-30 years old at that time; patented in 2002. USPP 12,439. Fruit: ovate; dark green; 425-567 g; averaging $8.75 \mathrm{~cm}$ diameter; excellent flavor; thick skin; pebbly textured; Season late, ripening in March. More resistant than other cultivars of its season to the pathogens Cercospora purpurea and Colletotrichum gloeosporioides. Tree: vigorous; upright growth; flowering type A.

Harvest. A large-fruited, late ripening avocado. Origin: Univ. of California, Davis, Calif., by B.O. Bergh and G.A. Martin. Gwen open pollinated; seed collected 1985; patented 2003. USPP 14238. Fruit: high spheroid shape; thick skin; black; large, 198-312 g; ratio (\%) seed/skin/flesh 15:14:71; late season. Tree: open, spreading growth habit; alternate bearing similar to Hass; flowering type A.

\section{TROPICAL FRUIT-MANGO}

Robert J. Knight, Jr.

Univ. of Florida, Tropical Research and Extension Center, Homestead

Alfa. A semi-dwarf mango. Origin: EMBRAPA Cerrado, Brasilia, Brazil. Mallika X Van Dyke. Fruit: large, 435 g; pink-red; firm; mediumfibrous; good quality (16\% SS, acidity $0.23 \%$, ratio Brix/acidity 70 ); no 
softnose internal breakdown. Tree: semi-dwarf; high yielding; resistant to oidium (Oidium mangiferae) and malformation; moderately resistant to anthracnose (Colletotrichum gloeosporioides).

Ataulfo. A polyembryonic mango, marketed in North America as "Champagne." Origin: Tapachula, Mexico. Open-pollinated seed brought from Costa Rica about 1930, selected in late 1950s. Fruit: small, 200-300 g; yellow; firm; stands shipping stress well; sweet with slight acidity; early to midseason. Tree: vigorous and upright; productive when young; resistant to anthracnose.

Beta. A mango. Origin: EMBRAPA Cerrado, Brasilia, Brazil, from a cross of Amrapali x Winters. Fruit: small, 310 g; yellow peel; firm; low fiber; excellent quality; $24.8 \% \mathrm{SS}$; acidity $0.16 \%$; ratio Brix/acidity 155. Tree: moderately vigorous; high yielding but irregular; without malformation; moderately resistant to anthracnose and oidium.

Bullock's Heart. A polyembryonic mango. Origin: Egypt. Fruit: large, $475 \mathrm{~g}$; peel light yellow with orange overlay and small white to green dots; flesh yellow to orange; ovate ("heart-shaped"); firm with no objectionable fibers; late-midseason; low quality. Tree: vigorous; upright; seed polyembryonic.

Cardozo Mankurad. A mango. Origin: Goa, India. Selected in 1992. Fruit: medium, 320 g; yellowish-orange with deep pink blush; pulp firm and melting with no objectionable fiber; deep orange; sweet and of excellent quality; $22.0 \%$ to $25.0 \% \mathrm{SS}$; shelf life $\sim 1$ week; early season. Tree: large; vigorous; canopy round and spreading; heavy yielding; regular bearing.

Chené. A mango. Origin: ARC-Institute for Tropical and Subtropical Crops, South Africa. Released 1996. Fruit: acceptable commercial size, $498 \mathrm{~g}$; Kent shaped; yellow with red blush; tastes excellent (12.5\% $\mathrm{SS}$ ) if tree- ripened but deteriorates rapidly in storage; recommended for immediate consumption but not for long distance shipment; early midseason. Tree: resists sun scorching; tolerates bacterial black spot.

Company. A mango. Origin: Egypt. Fruit: large, 565 g; yellow with no blush and medium-sized corky yellow dots; ovate-oblong in shape; flesh yellow; susceptible to "jelly seed" internal breakdown; juicy with no objectionable fiber; mild taste; acceptable but not outstanding quality, late season; seed polyembryonic. Tree: vigorous.

Excellent Succari. A mango. Origin: Egypt. Fruit: small, 280 g; green with yellow overlay and small, yellow smooth dots; ovate-oblong in shape; flesh orange; melting without "jelly seed" internal breakdown; juicy, with no objectionable fibers; delightful sweet taste; excellent quality; seed polyembryonic; late midseason. Tree: vigorous.

Genovea. A mango. Origin: Egypt. Fruit: small, 235 g; green with a yellow overlay and medium-sized smooth yellow dots; ovate-oblong shaped; flesh orange; firm; no "jelly seed" internal breakdown; juicy, with no objectionable fiber; sweet, agreeable taste; acceptable quality; polyembryonic; late midseason. Tree: vigorous.

Hindi Besennara. A mango. Origin: Egypt. Fruit: small to medium, $319 \mathrm{~g}$; green with orange overlay with small white corky dots; oblongcylindrical shaped; flesh orange; juicy with no objectionable fiber; pleasantly sweet; good quality; polyembryonic; early season. Tree: medium vigor.
Hindi Khassa. A mango. Origin: Egypt. Fruit: medium to large, 461 g; yellow with no blush and intermediate-sized smooth, light-yellow dots; oblong-cylindrical; flesh orange; firm; juicy with no objectionable fiber; low quality; late midseason. Tree: vigorous.

Mesk. A mango. Origin: Egypt. Fruit: small to medium, 313 g; yellow with a red blush, with small yellow dots corky in texture; ovate-oblong in shape; flesh orange; often with "jelly seed" internal breakdown; juicy with no objectionable fibers; sweet and agreeable in taste; very good quality; polyembryonic; late season. Tree: vigorous.

Joa. A promising mango cultivar that ships well. Origin: ARC-Institute for Tropical and Subtropical Crops, South Africa. Seedling of Palmer; released 1996. Fruit: commercially acceptable size, $427 \mathrm{~g}$; taste very good $\left(17.5^{\circ}\right.$ Brix $)$; deep red blush; ships well; early midseason. Tree: high tolerance to bacterial black spot (Pseudomonas syringae pv. syringae) and sun scorching

Lita. A mango. Origin: EMBRAPA Cerrado, Brasilia, Brazil. Amrapali x Tommy Atkins. Fruit: medium-large, 414 g; very firm with low fiber; excellent quality (18-20\% SS, $0.20 \%$ acidity, Brix/acidity ratio 90-100). Tree: vigorous; high-yielding; regular bearing; moderately resistant to anthracnose, oidium and malformation.

Nabeel. A mango. Origin: Egypt. Fruit: large, 495 g; ovate-oblong; flesh orange; firm; juicy without objectionable fiber; passable taste; acceptable quality; polyembryonic; midseason. Tree: adequate vigor.

Nam Doc Mai. A polyembryonic mango. Origin: Thailand. Fruit: moderately large, 340-580 g; yellow with slight pink blush and many small green dots; pulp without objectionable fiber; spicy and very sweet with a pleasant aroma; excellent quality; a thin, papery stone; early midseason. Tree: vigorous; medium-size; upright, dense canopy; high resistance to anthracnose and to bacterial black spot in Australia; productive.

Okrung. A polyembryonic mango. Origin: Thailand. Fruit: small, 160-240 g; sigmoid in shape; yellow or greenish; thick, tough skin; soft juicy pulp with abundant fiber; mild and very sweet, somewhat insipid but with agreeable aroma; midseason.Tree: moderately vigorous; medium-size; upright; dense canopy; highly productive.

Roxa. A mango. Origin: EMBRAPA Cerrado, Brasilia, Brazil. Amrapali x Tommy Atkins. Fruit: small; 287 g; purple-reddish; very firm and fiberless; excellent quality ( $19 \%$ to $21 \%$ SS, $0.12 \%$ acidity, Brix/ acidity ratio 158-175). Tree: moderately vigorous; medium-yielding; regular bearing; susceptible to mealybugs; medium to low resistance to anthracnose, oidium and malformation.

White Succari. A mango. Origin: Egypt. Fruit: medium-large; 410 g; greenish-yellow with yellow overlay, small smooth brown dots; oblong-cylindrical; flesh orange; juicy with no objectionable fiber; an agreeable sweet taste of very good quality; polyembryonic; early season. Tree: vigorous.

Zebda. A mango. Origin: Egypt. Fruit: large; 660 g; green with no overlay, with light brown smooth-textured dots; oblong-cylindrical with deep stem-end cavity; flesh deep orange; firm; juicy, without objectionable fiber; mild sweet taste; acceptable quality; polyembryonic; late midseason. Tree: vigorous; regularly productive. 


\section{INDEX OF CULTIVARS DESCRIBED}

12-76-71 GRAPE

13-19-30 GRAPE

13-21-12 GRAPE

13-29-281 GRAPE

13N0770 CHERRY-SWEET

13S2009 CHERRY-SWEET

14-44-248 GRAPE

14-48-258 GRAPE

15-97-77 GRAPE

8S6923 APPLE

92-95-99 PLUM

Abundance BLUEBERRY

Aita RASPBERRY

Alapaha BLUEBERRY

Alba STRAWBERRY

Albion STRAWBERRY

Alfa MANGO

Alpha Krome AVOCADO

Alvi RASPBERRY

Amfora BLUE HONEYSUCKLE

APF-12 BLACKBERRY AND HYBRID BERRY

APF-8 BLACKBERRY AND HYBRID BERRY

Apodi (BRS 235) ACEROLA

Arian APPLE

ARS 96-138 BLUEBERRY

Asia STRAWBERRY

Ataulfo MANGO

August Bright NECTARINE

August Giant PLUM

August Yummy® PLUM

Aurora BLUEBERRY

Aurora Golden Gala ${ }^{\mathrm{TM}}$ APPLE

Autumn Blaze NECTARINE

Autumn King GRAPE

Barrier 1 PEACH ROOTSTOCK

Barrier 1 PLUM ROOTSTOCK

Benefis RASPBERRY

Benton ${ }^{T M}$ CHERRY-SWEET

Berry Blue ${ }^{\circledR}$ BLUE HONEYSUCKLE

Beta MANGO

BG-269 STRAWBERRY

BG-625 STRAWBERRY

BG-633 STRAWBERRY

Big Red PLUM

Bish STRAWBERRY

Black Diamond BLACKBERRY AND HYBRID BERRY

Black Pearl BLACKBERRY AND HYBRID BERRY

Black York ${ }^{\mathrm{TM}}$ CHERRY-SWEET

BlackGold ${ }^{\mathrm{TM}}$ CHERRY-SWEET

Blue Belle ${ }^{\circledR}$ BLUE HONEYSUCKLE

Blue Bird ${ }^{\circledR}$ BLUE HONEYSUCKLE

Blue Forest ${ }^{\circledR}$ BLUE HONEYSUCKLE

Blue Lightning $®$ BLUE HONEYSUCKLE

Blue Moon ${ }^{\circledR}$ BLUE HONEYSUCKLE

Blue Nova ${ }^{\circledR}$ BLUE HONEYSUCKLE

Blue Pacific ${ }^{\circledR}$ (BLUE HONEYSUCKLE

Blue Sky® BLUE HONEYSUCKLE

Blue Velvet ${ }^{\circledR}$ BLUE HONEYSUCKLE

BlushingGold ${ }^{\mathrm{TM}}$ CHERRY-SWEET

Bright Princess PEACH

Bright Sweet NECTARINE

Brown CHERRY-SWEET

Brown CHERRY-SWEET

Bullock's Heart MANGO

Burnecteleven NECTARINE

Burnectfive NECTARINE
Burnectfour NECTARINE

Burnecthree NECTARINE

Burnectone NECTARINE

Burnectseven NECTARINE

Burnectseventeen NECTARINE

Burnectsix NECTARINE

Burnectsixteen NECTARINE

Burnectten NECTARINE

Burnectthirteen NECTARINE

Burnecttwelve NECTARINE

Burnecttwo NECTARINE

Burpeacheight PEACH

Burpeacheleven PEACH

Burpeachfifteen PEACH

Burpeachfive PEACH

Burpeachfour PEACH

Burpeachfourteen PEACH

Burpeachnine PEACH

Burpeachnineteen PEACH

Burpeachone PEACH

Burpeachseven PEACH

Burpeachseventeen PEACH

Burpeachsix PEACH

Burpeachsixteen PEACH

Burpeachten PEACH

Burpeachthirteen PEACH

Burpeachthree PEACH

Burpeachtwelve PEACH

Burpeachtwenty PEACH

Burpeachtwo PEACH

Cal Giant STRAWBERRY

Calara PEACH

Camellia BLUEBERRRY

Camellia BLUEBERRY

Cardozo Mankurad MANGO

Carmela STRAWBERRY

Carmine STRAWBERRY

Cereja (BRS 236) ACEROLA

Charlotte STRAWBERRY

Chelsea Pensioner STRAWBERRY

Chemainus RASPBERRY

Chené MANGO

Chesapeake BLACKBERRY AND HYBRID BERRY

Chesapeake BLACKBERRY

Chiflón® STRAWBERRY

Chinook RASPBERRY

Christine STRAWBERRY

Christine STRAWBERRY

Civni APPLE

Civni APPLE

Clark Gold BLACKBERRY AND HYBRID BERRY

Coelho NECTARINE

Columbia CHERRY-SWEET

Columbia CHERRY-SWEET

Company MANGO

Comtesse RASPBERRY

Controller $5^{\mathrm{TM}}$ PEACH ROOTSTOCK

Controller $5^{\mathrm{TM}}$ PLUM ROOTSTOCK

Controller 9TM PEACH ROOTSTOCK

Controller 9 $9^{\mathrm{TM}}$ PLUM ROOTSTOCK

Coop-29 APPLE

Coop-33 APPLE

Coop-39 APPLE

Coop-43 APPLE

Crimson Crisp ${ }^{\mathrm{TM}}$ APPLE

Czech No. 17 BLUE HONEYSUCKLE

D6N-72 PLUM

Dalitron APPLE 
Dame Nancy CHERRY-SWEET

Dame Roma CHERRY-SWEET

Dange STRAWBERRY

Desertnaya BLUE HONEYSUCKLE

DeSoto BLUEBERRRY

DeSoto BLUEBERRY

Die G et PEACH ROOTSTOCK

Dimka BLUE HONEYSUCKLE

Dixieblue BLUEBERRY

Dora STRAWBERRY

Doty CHERRY-SWEET

Draper BLUEBERRY

Draper BLUEBERRY

Driscoll Agoura STRAWBERRY

Driscoll Camarillo STRAWBERRY

Driscoll Cambria STRAWBERRY

Driscoll Cardinal RASPBERRY

Driscoll Carmel BLACKBERRY AND HYBRID BERRY

Driscoll Carmelina RASPBERRY

Driscoll Coronation STRAWBERRY

Driscoll Cowles BLACKBERRY AND HYBRID BERRY

Driscoll Dulcita RASPBERRY

Driscoll Eureka BLACKBERRY AND HYBRID BERRY

Driscoll Francesca RASPBERRY

Driscoll Jubilee STRAWBERRY

Driscoll Lanai STRAWBERRY

Driscoll Malibu STRAWBERRY

Driscoll Maravilla RASPBERRY

Driscoll Marin STRAWBERRY

Driscoll Osceola STRAWBERRY

Driscoll Sonoma BLACKBERRY AND HYBRID BERRY

Driscoll Madonna RASPBERRY

Early Robin ${ }^{\mathrm{TM}}$ CHERRY-SWEET

Eden $^{\text {TM }}$ APPLE

Emerald Gem PLUM

Eva STRAWBERRY

Excel PECAN

Excellent Succari MANGO

F-1-9-58 BLUE HONEYSUCKLE

Fialka BLUE HONEYSUCKLE

Flavor Wynee PLUM

Florida Rose BLUEBERRY

Franor STRAWBERRY

Frutacor (BRS 238) ACEROLA

G.11 APPLE

G.16 APPLE

G.41 APPLE

G.202 APPLE

G-435 BLUEBERRY

G.935 APPLE

Galarina $^{\mathrm{TM}}$ APPLE

Gemma STRAWBERRY

Geneva ${ }^{\circledR} 11$ APPLE

Geneva ${ }^{\circledR} 16$ APPLE

Geneva ${ }^{\circledR} 41$ APPLE

Geneva ${ }^{\circledR} 202$ APPLE

Geneva ${ }^{\circledR} 935$ APPLE

Genovea MANGO

George Bugnet BLUE HONEYSUCKLE

Georgia RASPBERRY

GI®2091 CHERRY ROOTSTOCK

Gisela®3 CHERRY ROOTSTOCK

Glenare CHERRY-SWEET

Glenoia CHERRY-SWEET

Glenred CHERRY-SWEET

Glenrock CHERRY-SWEET

Goluboye Verenteno BLUE HONEYSUCKLE

GR7 GRAPE
Gulfbeauty PLUM

Gulfbeauty PLUM

Gupton BLUEBERRY

Haas CHERRY-SWEET

Harvest AVOCADO

Helkal RASPBERRY

Hindi Besennara MANGO

Hindi Khassa MANGO

Holiday PLUM

Honey Diva NECTARINE

Honey Fire NECTARINE

Honey Haven NECTARINE

Honey Sweet PLUM

Ivushka BLUE HONEYSUCKLE

Jaclyn RASPBERRY

Jazz® APPLE

Jeanne GOOSEBERRY

Joa MANGO

Joan Irene RASPBERRY

Julia Bugnet BLUE HONEYSUCKLE

Juliet ${ }^{\mathrm{TM}}$ APPLE

Kapel BLUE HONEYSUCKLE

Kettleman APRICOT

Kiev No. 8 BLUE HONEYSUCKLE

Klamath PEACH

Krymsk $1^{\text {TM }}$ PLUM ROOTSTOCK

Krymsk $2^{\mathrm{TM}}$ PEACH ROOTSTOCK

Krymsk 2TM PLUM ROOTSTOCK

Krymsk® 5 CHERRY ROOTSTOCK

Krymsk@5 CHERRY ROOTSTOCK

Krymsk®6 CHERRY ROOTSTOCK

La Crescent GRAPE

Laska RASPBERRY

Late Pearl NECTARINE

LC-52 CHERRY ROOTSTOCK

Liberty Bell CHERRY-SWEET

Liberty Bell CHERRY-SWEET

Liberty BLUEBERRY

Lita MANGO

Loch Tay BLACKBERRY AND HYBRID BERRY

Lynn APPLE

MacExcel APPLE

Magadan BLUE

HONEYSUCKLE

Malling Minerva RASPBERRY

Mann PLUM

Marcia's Flavor PLUM

Marina STRAWBERRY

Marquette GRAPE

Marwe RASPBERRY

May Sweet PEACH

MC38 APPLE

Medina STRAWBERRY

Mesk MANGO

Metolius BLACKBERRY AND HYBRID BERRY

Minnie Royal CHERRY-SWEET

Morena BLUE HONEYSUCKLE

Myrobalan RI-1 CHERRY ROOTSTOCK

Nabeel MANGO

Nam Doc Mai MANGO

Native Blue BLUEBERRY

NB-1 STRAWBERRY

New Ruby STRAWBERRY

NF 205 STRAWBERRY

NF 245 STRAWBERRY

NF 302 STRAWBERRY

NF 311 STRAWBERRY

Nicola STRAWBERRY 
Nicola ${ }^{\text {TM }}$ APPLE

Nightfall BLACKBERRY AND HYBRID BERRY

Novablue BLUEBERRY

Novinka BLUE HONEYSUCKLE

Nymfa BLUE HONEYSUCKLE

Obsidian BLACKBERRY AND HYBRID BERRY

Okrung MANGO

Opal APPLE

Palmetto BLUEBERRY

Pavlovskaya BLUE HONEYSUCKLE

PC8011-3 CHERRY-SWEET

Pendleton CHERRY-SWEET

PF 11 NECTARINE

PF $24 \mathrm{C}$ PEACH

PF 9A-007 PEACH

PF Lucky 21 PEACH

PiKu®1 CHERRY ROOTSTOCK

PiKu®3 CHERRY ROOTSTOCK

PiKu@4 CHERRY ROOTSTOCK

Pixie Crunch ${ }^{\mathrm{TM}}$ APPLE

Plablanec NECTARINE

Plahuelfre STRAWBERRY

Plarionfre STRAWBERRY

Platornec NECTARINE

Plumsweetone PLUM

Plumsweettwo PLUM

Plumsweetthree PLUM

Polesie RASPBERRY

Prime-Jan ${ }^{\text {TM }}$ BLACKBERRY AND HYBRID BERRY

Prime-Jim ${ }^{\mathrm{TM}}$ BLACKBERRY AND HYBRID BERRY

PS-592 STRAWBERRY

PS-1049 RASPBERRY

PS-1703 RASPBERRY

PS-2880 STRAWBERRY

Rafzicta GOOSEBERRY

Rafzuera GOOSEBERRY

Rassvet BLUE HONEYSUCKLE

Rebel BLUEBERRY

Rebella APPLE

Record STRAWBERRY

Reinette Russet ${ }^{\mathrm{TM}}$ APPLE

Rose Bright NECTARINE

Roxa MANGO

Roxana STRAWBERRY

Roxinha (BRS 237) ACEROLA

Royal Bright NECTARINE

Royal Dawn CHERRY-SWEET

Royal Kay CHERRY-SWEET

RS-3 GRAPE ROOTSTOCK

RS-9 GRAPE ROOTSTOCK

Rubens ${ }^{\circledR}$ APPLE

Ruby Queen PLUM

Saanich RASPBERRY

Tomo RASPBERRY

Saulene STRAWBERRY

Savory BLUEBERRY

Scarlet Royal GRAPE

Scifresh APPLE

Selah ${ }^{\text {TM }}$ CHERRY-SWEET

September Yummy® PLUM

Sequoia ${ }^{\text {TM }}$ CHERRY-SWEET

Sertaneja ACEROLA

Shenandoah PEAR

Shimei 3 STRAWBERRY

Shimei 4 STRAWBERRY

Sierra Gem PEACH

Sinyaya Pititsa BLUE HONEYSUCKLE

Sir Don CHERRY-SWEET
Sir Douglas CHERRY-SWEET

Sir Hans CHERRY-SWEET

Sir Tom CHERRY-SWEET

SJ 303 APPLE

SJCA38R6A74 APPLE

Smokey Blue ${ }^{\circledR}$ BLUE HONEYSUCKLE

Snow Fall PEACH

Snow Peak PEACH

SouthernGiant ${ }^{\mathrm{TM}}$ PEACH ROOTSTOCK

SPA440 APPLE

Splash PLUM

Spring Candy PEACH

Spring Flavor PLUM

Spring Pearl NECTARINE

Springhigh BLUEBERRY

Springwide BLUEBERRY

Staccato $^{\text {TM }}$ CHERRY-SWEET

Stardust ${ }^{\mathrm{TM}}$ CHERRY-SWEET

Starking® PEACH ROOTSTOCK

Start BLUE HONEYSUCKLE

Stella Minnesota APPLE

Strawberry Festival STRAWBERRY

Suaprinine APRICOT

Suapriten APRICOT

Sugar Lia STRAWBERRY

Sugar Time PEACH

Sugarpeach PEACH

Sugratwentysix GRAPE

Sugratwentyseven GRAPE

Sugratwentyeight GRAPE

Sundance ${ }^{\mathrm{TM}}$ APPLE

Sunset Bing ${ }^{\text {TM }}$ CHERRY-SWEET

Super Lady PEACH

Suplumtwentyfive PLUM

Suplumtwentysix PLUM

Suplumtwentyseven PLUM

Suplumtwentyeight PLUM

Suplumtwentynine PLUM

Suplumthirtythree PLUM

Suplumthirtyfour PLUM

Suplmthirtyfive PLUM

Sweet Alice PEACH

Sweet August NECTARINE

Sweet Henry PEACH

Sweet Scarlet GRAPE

Sweet Shasta PEACH

Sweet Surprise NECTARINE

Sweetcot PLUM

Taylor 14L22 NECTARINE

Tixia $^{\text {TM }}$ GOOSEBERRY

Tomichka BLUE HONEYSUCKLE

Triplett Blanc GRAPE

UCMH 55 CHERRY ROOTSTOCK

UCMH 56 CHERRY ROOTSTOCK

UCMH 59 CHERRY ROOTSTOCK

UEB 3264/2 APPLE

UEB 3375/2 APPLE

Valentina RASPBERRY

Valery No. 2 BLUE HONEYSUCKLE

Vernon BLUEBERRY

Viola BLUE HONEYSUCKLE

VSL-2 CHERRY ROOTSTOCK

Waco PEACH ROOTSTOCK

Wendy STRAWBERRY

Western Sweet NECTARINE

White County PEACH

White Rock PEACH

White Succari MANGO 
Xavante BLACKBERRY AND HYBRID BERRY

Xenia $^{\text {TM }}$ GOOSEBERRY

Yummy®crisp PLUM

Yummy®gem PLUM

Zarnitsa BLUE HONEYSUCKLE

Zebda MANGO

Zolushka BLUE HONEYSUCKLE

\section{ADDENDA AND REVISIONS TO PREVIOUS LISTS}

BLACKBERRY

Chesapeake. USPP 13,878, 17 June 2003. (List 41)

BLUEBERRY

Alapaha. USPP16,266 issued. (List 41)

Aurora. USPP15,185 issued. (List 42)

Liberty. USPP15,146 issued. (List 42)

Draper. USPP15,103 issued. (List 42)

CHERRY- SWEET

BlackGold $^{\text {TM }}$. USPP 15,847 (List 41)

Columbia. Now called Benton ${ }^{\mathrm{TM}}$, USPP 15,847. (List 41)

Liberty Bell. Now called Selah ${ }^{\mathrm{TM}}$, USPP 16,135. (List 41)

GRAPE

La Crescent. USPP14,617 issued 23 March. (List 41)

PLUM

Gulfbeauty. USPP 11,224. (List 41)

PRUNUS ROOTSTOCK

Krymsk $1^{\mathrm{TM}}$ (VVA-1). USPP 15,995 issued 27 Sept. 2005. (List 42)

RASPBERRY

Chemainus. Misspelled as Chemaimus in List 42.

STRAWBERRY

Bish. USPP15,552 issued. (List 42)

Cal Giant 5. USPP15,087 issued. (List 42)

Christine. Misspelled when published as Christina in List 41.

Strawberry Festival. USPP14,739 issued. (List 42)

\section{PREVIOUS LISTS}

List 42 in HortScience 39(6); 1509-1523 (2004).

List 41 in HortScience 37(2); 251-272 (2002).

List 40 in HortScience 35(5); 812-826 (2000).

List 39 in HortScience 34(2); 181-205 (1999).

List 38 in HortScience 32(5);785-805 (1997).

List 37 in HortScience 30(6):1135-1150 (1995).

List 36 in HortScience 29(9):942-969 (1994).

Earlier Lists are included in the Brooks and Olmo Register of Fruit and Nut Varieties, 3rd ed. (1997), ASHS Press. This book also includes a few previously undescribed cultivars which appeared later in Lists $36-41$. 